\title{
الإنسان في المرجعية المتجاوزة عند عبد الوهاب المسيري
}

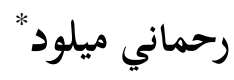

$$
\begin{aligned}
& \text { الملخص } \\
& \text { يحتل موضوع الإنسان مكانة مركزية في فكر عبد الوهاب المسيري بصفة عامة. وقد تناولت هذه الدراسة مفهوم } \\
& \text { المرجعية بشقيها: المتجاوزة والكامنة، ثم تطرقت إلى رؤية المسيري للإنسان في المرجعية المتجاوزة بالحديث عن عن الثنائيات } \\
& \text { الفضفاضة، ولا سيّما ثنائية الخالق والمخلوق، ثم تركيبية الإنسان الذي لا يمكن اختزاله في بُعد واحد، مركّزة على فطرية }
\end{aligned}
$$

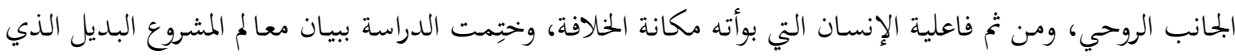

$$
\begin{aligned}
& \text { اقترحه المسيري، وبيان منطلقات هذا المشروع وخصائصه وشروط تحققه. } \\
& \text { الكلمات المفتاحية: عبد الوهاب المسيري، المرجعية المتجاوزة، المرجعية الكامنة، الثنائيات الفضفاضة، الرؤية } \\
& \text { التوحيدية، المشروع الحداثي العربي الإسلامي. }
\end{aligned}
$$

\section{Mankind in Abdelwahab el-messiri's surpassing frame of reference}

\section{Abstract}

Mankind occupies a central position in Abdelwaheb Elmassiri thought. This study has dealt with the concept of intellectual frame of reference in its two types: surpassing and latent. It then studied El-Messiri's view of Man within the loose dualities, especially the duality of The Creator and the created. He views man as a composite that can't be reduced to one dimension ignoring the innate spiritual side which qualified him for the status of vicegerency. The study ended with introducing the milestones of ElMessiri's alternative project, delineating the projects basis, characteristics and the necessary conditions to allow this project to materialize.

Keywords: Abdelwahab El-Mesiiri, surpassing frame of reference, latent frame of reference, loose dualities, tawhidi worldview, Arabic Islamic modernity project.

$$
\text { * ماجستير في الفلسفة الإسلامية، يعمل حالياً أستاذاً بجامعة فرحات عباس، سطيف البحث الجزائر. البريد الإلكتروبي: }
$$


مقدمة:

ظلـت مشـكلة الإنسـان موضـوع بحـاذب فكـــي وفلسـفي بـين مختلـف المـذاهب

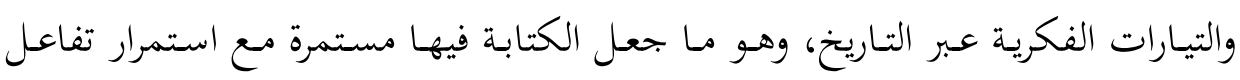

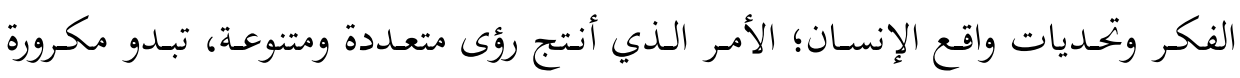

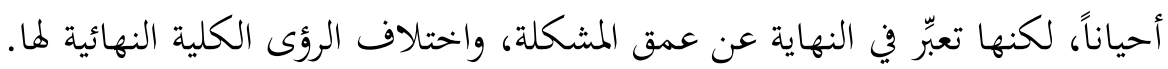
وعلى الرغم من التطور المنهجي الذي عرفته العلوم الإنسانية والاجتماعية واتساع السقف المعرفي، إلا أن المشكلة ظلت ملازمة للفكر في كل مساراته عبر التاريخ الإنساني،

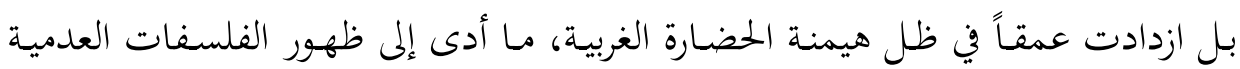
وموت الإنسان؛ الأمر الذي دفع إلى ظهور موجة نقدية عارمة من داخحل النسق الغربي

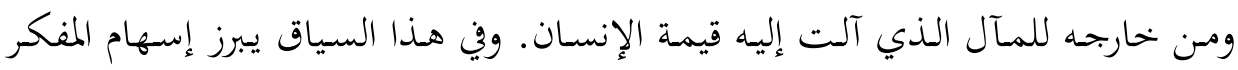
الإسلامي العالمي عبد الوهاب المسيري في نقده الحضارة الغربية والنموذج المعريي الغربي؛ إذ يحتل موضوع الإنسان مكانة مركزية في فكره.

وينصب اهتمام المسيري في جل إنتاجـه المعرفي على نقد الحضـارة الغربية ونموذجها المعريف؛ الذي يشير فيه إلى ظاهرة ذات دلالة عميقة، هي التناقض الصارخ في تطور دلالة

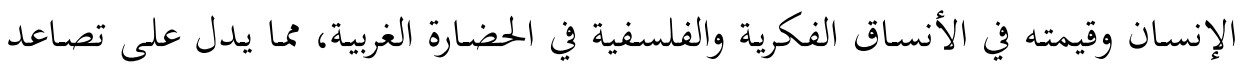

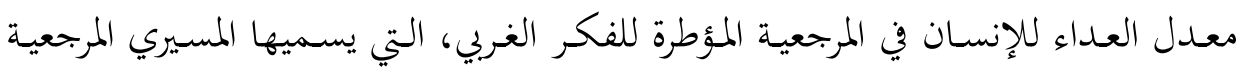

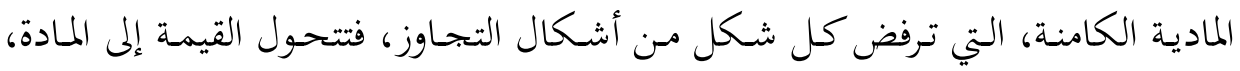
وبذلك يتغير المطلق المعريف. ويف المقابل فإن المسيري يطرح رؤية كلية عن الإنسان تصدر

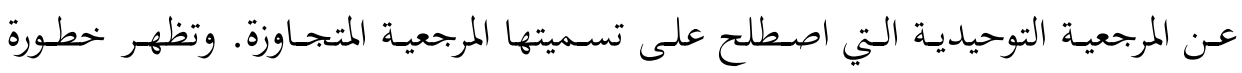
انحراف الرؤيـة المعرفيـة للإنسـان في تمظهراتها على النظم السياسية والاقتصـادية والثقافيـة

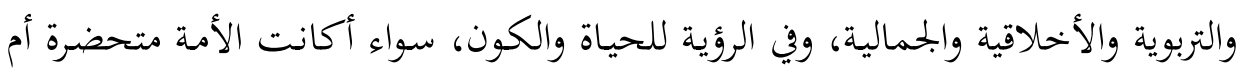
متخلفة. فعلى الرغم من تطور الحضارة الغربية وهيمنتها، إلا أن انحراف رؤيتها للإنسان إنهان

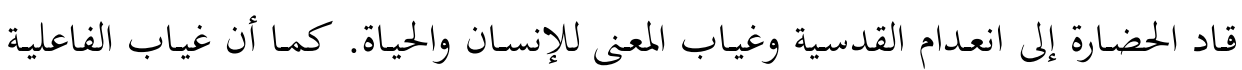


في رؤيـة الحضـارة العربيـة الإسـلامية للإنسـان -على الـرغم مـن حفاظهـا على الرؤيـة التوحيدية- ساق الأمة إلى قاع التخلف.

وهنا تبرز أهمية طرح المسيري؛ سواء في نقده النموذج المعريف الغربي في رؤيته للإنسان

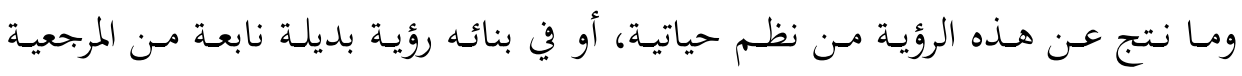

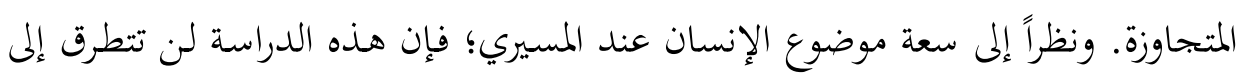

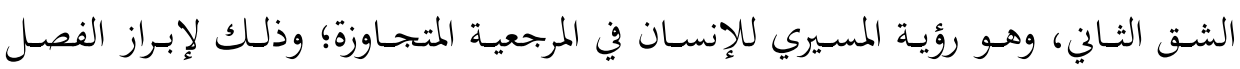

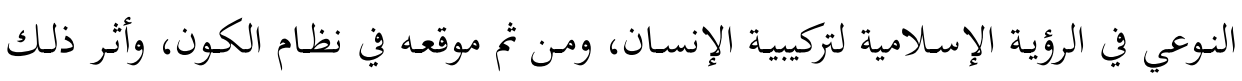
كله في النظم الحياتية للحضارة.

\section{أولاً: المرجعية المتجاوزة والمرجعية الكامنة: مساءلة مفاهيمية}

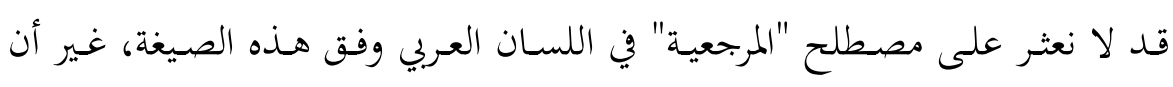

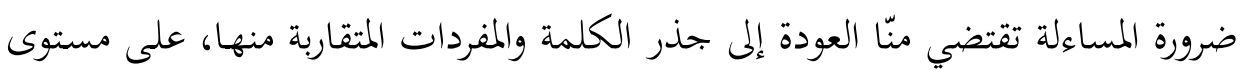

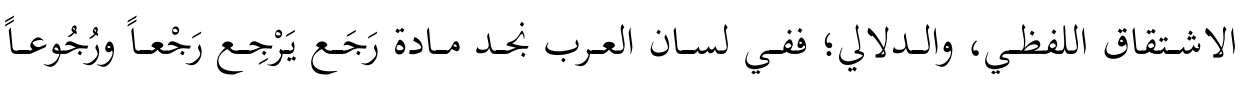

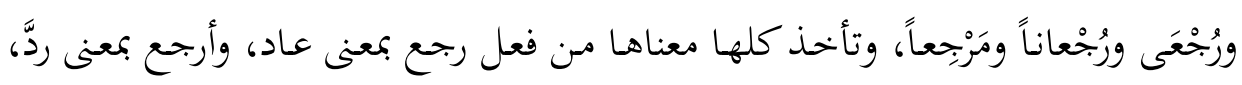

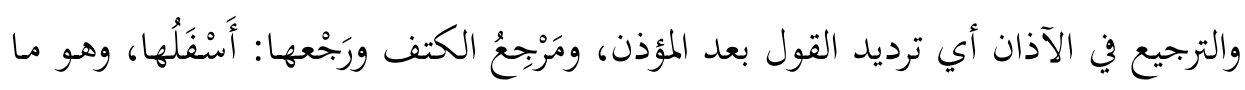

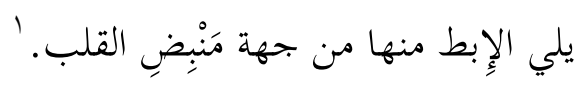

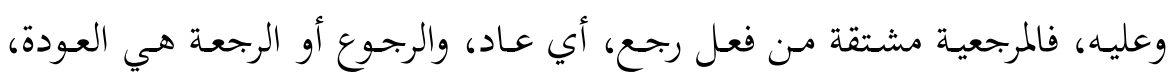

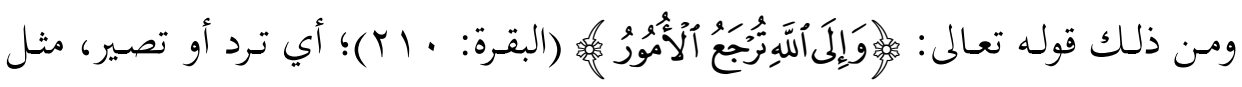

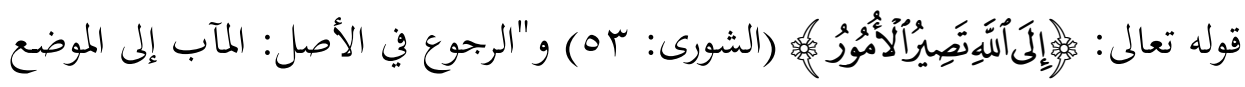

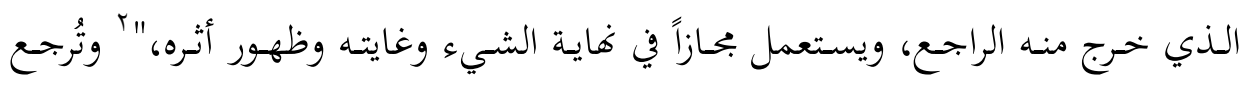

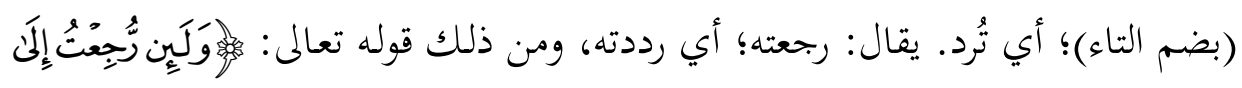

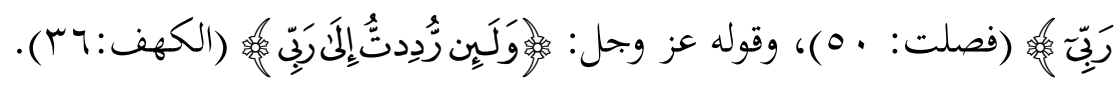

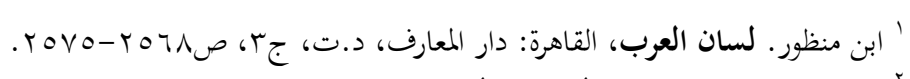

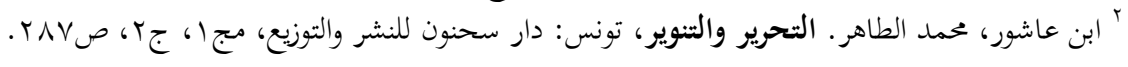




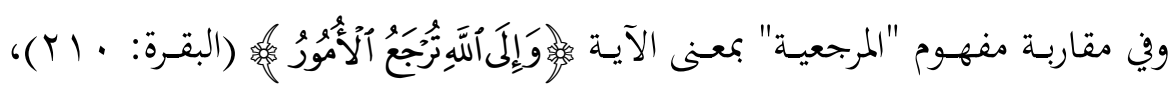

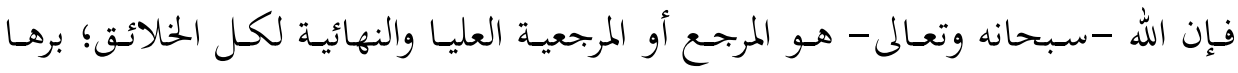
وفاجرها. ووفي هذا المعنى يقول الفخر الرازي: "إن ذوات اللنلق وصفاهم لما كانت شاهدة عليهم بـأفم مخلوقون محُدثون محاسبون، كانوا رادين أمرهم إلى الله، إلى خـالقهم، فقوله

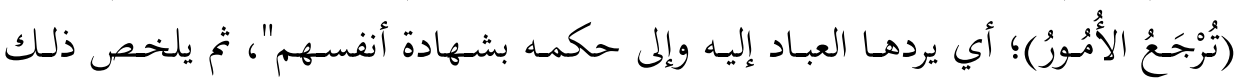
بقوله: "إن العبـاد يـردون أمسورهم إلى الله، ويعترفون برجوعهـا إليـه، أمـا المؤمنـون فبالمقـال

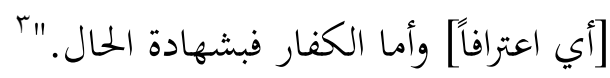

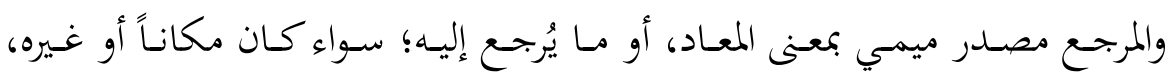
فنقول: كتاب مرجع؛ أي هو الذي يُرجع إليه في موضوع مـا؛ نظراً إلى تخصصه فيه أو إحاطته بـه، ونقول: رجل مرجح؛ أي هـو الذي يُرجع إليه في الحكم أو في الرأي. وبذا، فالمرجعية هي الفكرة أو العقيدة التي يُرجع إليها في كل الأمور، والتي تحدد توجه الإنسان في مـا يخـص حياتـه ومذهبـه وملامـح فكره، سـواء أكانـت هـذه الفكرة أم العقيـدة دينيـة غيبية كما هي الحال في الأديان، أو كانت غير ذلك كما هو الشأن في المذاهب الفكرية والفلسفية.

أمـا عند المسـيري فهي: "الفكرة الجوهرية التي تشكل أسـاس كل الأفكار في نموذج معين، والركيزة النهائية الثابتة له، التي لا يمكـن أن تقـوم رؤيسة العالم دوهـا، والمبـدأ الواحد الذي ترد إليه كل الأشياء ولا يرد هو أو ينسب إليها." ويعرفها أيضاً بقوله: "هي المطلق المكتفي بذاته والذي يتجاوز كل الأفراد والأشياء والظواهر، وهو الذي يمنح العالم تماسكه ونظامه ومعناه، ويهاد حلاله وحرامه، وعادة ما نتحدث عن المرجعية النهائية باعتبار أنها أعلى مستويات التجريد، تتجاوز كل شيء ولا يتجاوزها شيء. "ه

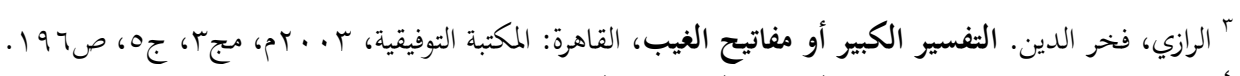

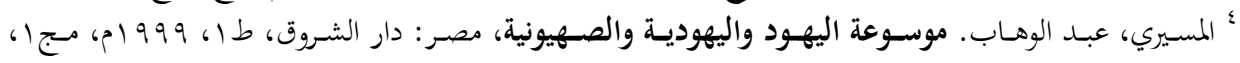
صعه.

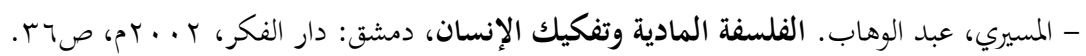

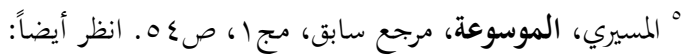

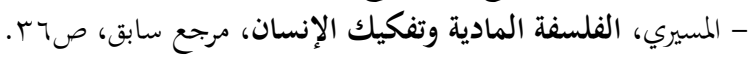


نلاحظ مـن التعريف الأول أن المرجعية تكون على مستوى الفكر. لذا، فهي فكرة جوهرية؛ أي الأساس الذي ينبثق عنه باقي الأفكار، وتكمسن جوهريتها في كوها الركيزة

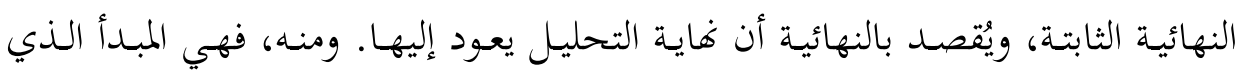

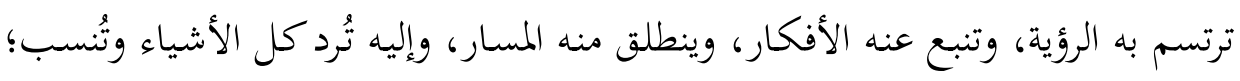

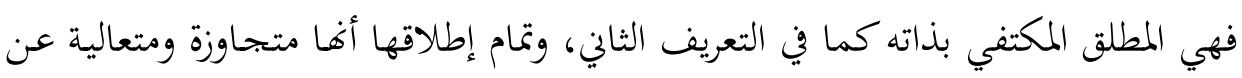
الأفراد والأشياء والظواهر، وحستى إذا كانـت هـذه المرجعيـة ماديـة متعينـة فهي متجـاوزة صاحبها؛ إذ تمنحه رؤية كلية فائية للوجود، وتحدد له سلوكه في الحياة. لذا، لا لا نستغرب عندما يقول المسيري إنه عادة ما يتحدث عن المرجعية بوصفها أعلى مستويات التجريد؛

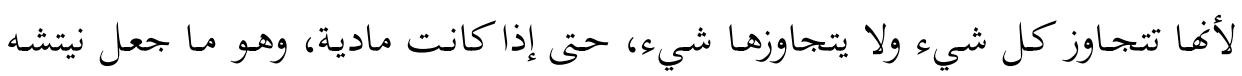

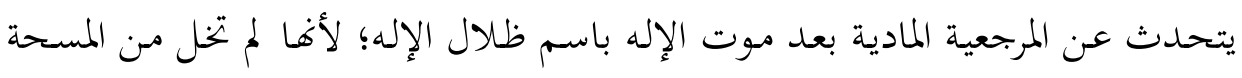
الميتافيزيقية.

\section{ا ـ مفهوم المرجعية المتجاوزة:}

يستعمل لفظ "التجاوز" بمعنى التعالي. وفي المعجم الفلسفي الصادر عن بحمع اللغة

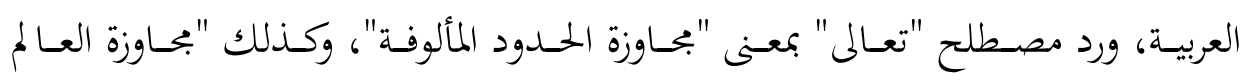

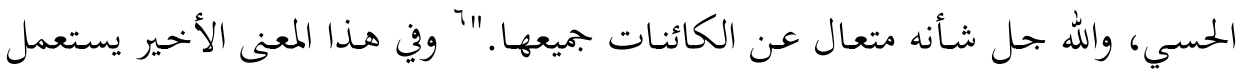

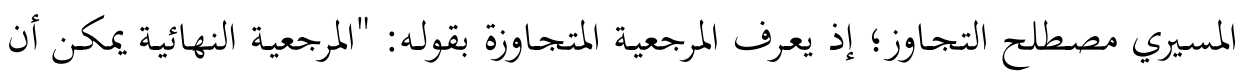
تكون نقطة خحارج عالم الطبيعة متجاوزة لما، وهي ما نسميه المرجعية المتجاوزة (للطبيعة والتاريخ والإنسان). هذه النقطة المرجعية المتجاوزة، في النظم التوحيدية، هي الإله الواحد

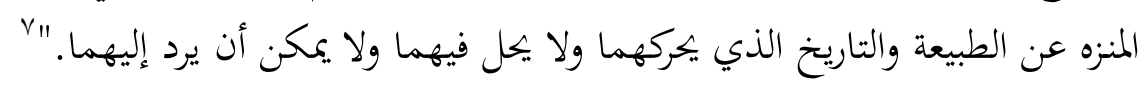

ينسب المسيري التجاوز إلى نقطة خارج عالم الطبيعة. ففي استعمال لفظة "نقطة" إبهام متعمد؛ تفادياً لتحييز المتجاوز في مكان أو زمان، أو تشخيصه في فكرة أو كيان مادي وهو ما تقتضيه صفة التجاوز والمتجاوز. فالتجاوز هو المسافة الفاصلة بين الله

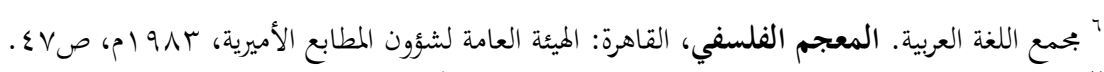

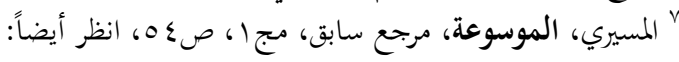

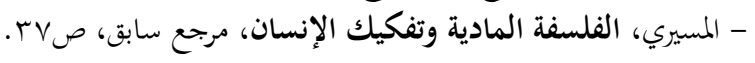


المتعالي الخالق المدبر والكون، وهو ما يمكن أن نعبّر عنه بثنائية الوجود الكبرى؛ طرفها الثاني أثر لطرفها الأول، ولذلك فهي ثنائية وليست إثنينية ندية، كما أن طرفها الثاني بلدوره ينقسم إلى ثنائية أخرى هي ثنائية الإنسان والطبيعة، وبالرغم من أن الإنسان يعيش إنى

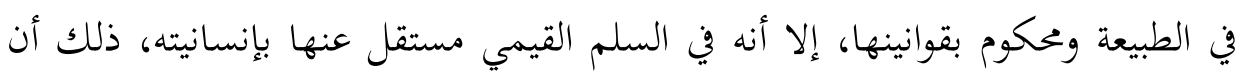
الله المتعالي، يهكم ثنائية الكون بقانون إلهي هو قانون الخلق والتدبير والمصير. ^ وأن الله تعالى أعطى الإنسان إرادة نسبية هي جزء من إرادته سبحانه وتعالى، وحمّله أمانة

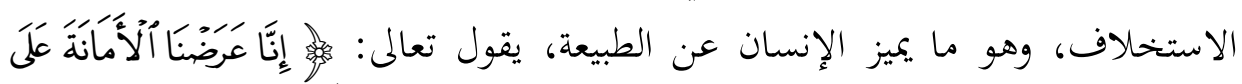

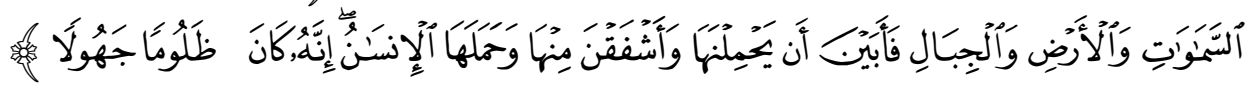
(الأحزاب: VY). ففي هذه الآية تظهر لنا ثنائية الطبيعة (الأرض والسموات والإنهات والجبال) والإنسان، وأن الله تعالى ميز الإنسان بأن حمّله الأمانة، التي هي استخلافه في الأرض. غير أن جوهر التجاوز في المرجعية المتجـاوزة، لا يكمـن في المسافة الفاصلة بـين الله المتعالي والكون فحسب، بل "هو ضمان أن المسافة التي تفصل الإنسان عن الطبيعة لن تختزل ولن تلغى، فالإنسان قد خحلقه الله ونفخ فيه من روحه وكرمه واستأمنه على العالم

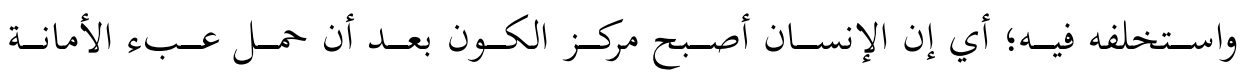
والاستخلاف. كل هذا يعني أن الإنسان يحوي داخله بشكل مطلق الرغبة في التجاوز ورفض الذوبان في الطبيعة، ولذا فهو يظل مقولة مستقلة داخل النظام الطبيعي، كما أنه

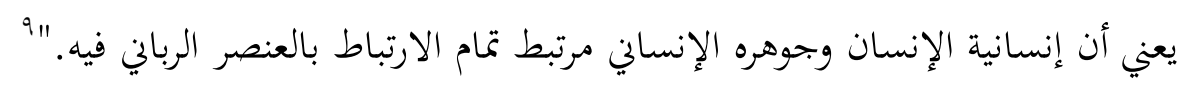
وإضـافة إلى تجاوز الله تعالى الكون بثنائيته، فإن بتحاوزه يشـمل التاريخ أيضاً، الذي

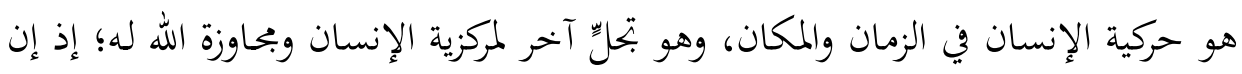

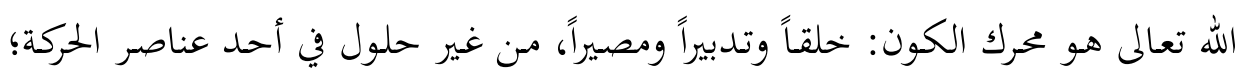
لأن الحلول يتناف والإطلاق، وينسف التجاوز الكلي، وهو ما يتجلّى بوضوح في دعاوى وحدة الوجود؛ سواء الروحية أو المادية.

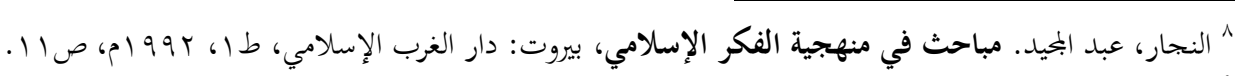

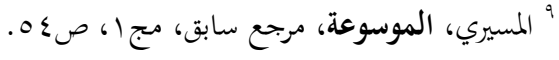


ولما كانت ثنائية الإنسان والطبيعة، المنبثقة عن ثنائية الله والعالمه، ثنائيةً فضفاضة كما

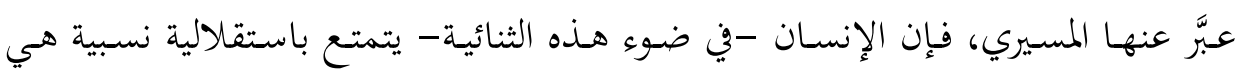

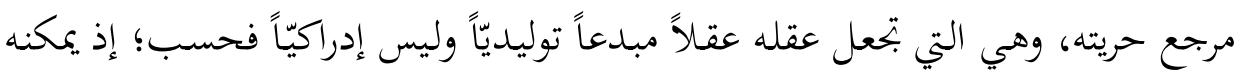

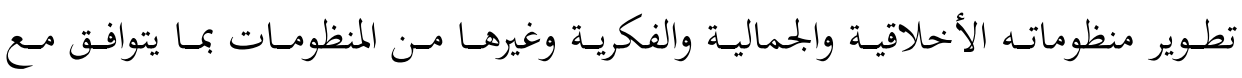
احتياجات العصر الذي يعيشه، وكذا ظروف المكان والزمان وملابساهما. وعليه، فقد أفرز التاريخ لنا حضارات متعددة في ظل المرجعية المتجاوزة التي عرفتها البشرية في تاريخها؛ أي إن نتاجها الحضاري اتسم بالتنوع، وهو تنوع مرده مقدرة الإنسان على إعادة صياغة ذاته وبيئته حسب وعيه الحر، وحسب ما يتوصل إليه من معرفة من خحلال تراكم بتاربه عبر التاريخ.

\section{Y ( مفهوم المرجعية الكامنة:}

ورد في لسان العرب لفظ كمن يكمن كمونا، بمعنى توارى واختفى، وبمعنى دخل في

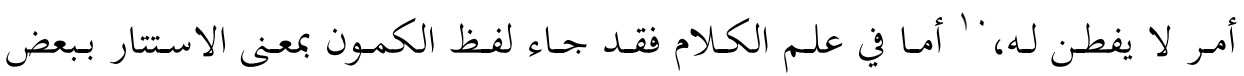

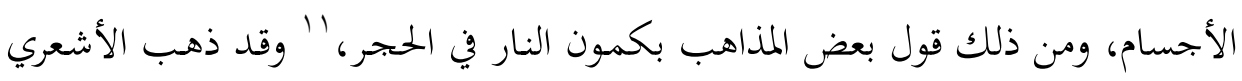

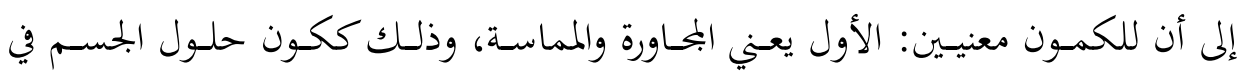

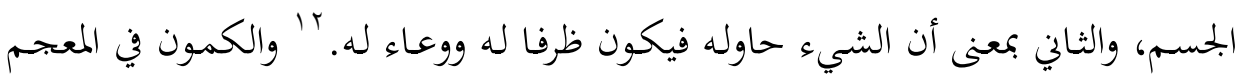
الفلسفي هو "ما ينطوي على الشيء بصفة دائمة، فيقال قوة كامنة، وفي مذهب وحدة

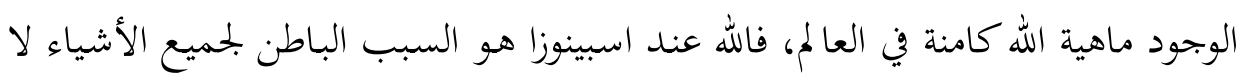

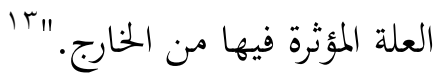

وهذا الأخير أقرب إلى مفهوم المرجعية الكامنة عند عبد الوهاب المسيري؛ إذ يعرفها

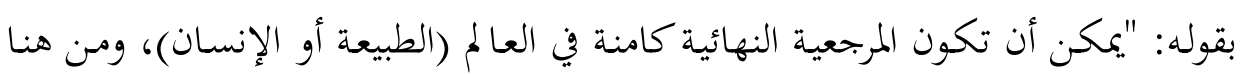

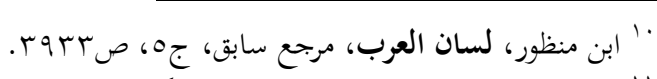

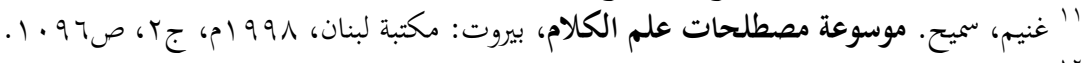

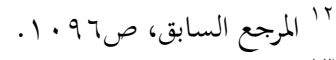

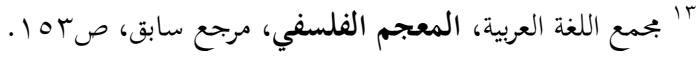


تسميتنا لها بالمرجعية الكامنة، ينظر للعالم على اعتبار أنه يجوي داخله ما يكفي لتفسيره

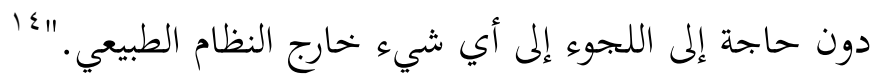

من النظرة الأولى إلى هذا التعريف يظهر لنا أن المرجعية الكامنة تكمن في الطبيعة أو

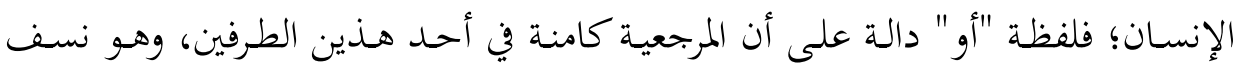
للثنائية، وسقوط في الواحدية؛ أي المبدأ الواحد الذي تُرد إليه كل الأشياء.

والفرق بـين الحلمول والكمـون هو أن الإله أو المرجع في حالة الحلـول يكسون خـارج

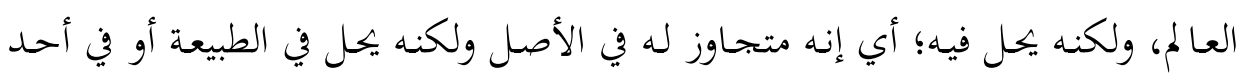

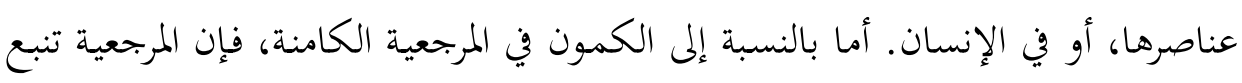

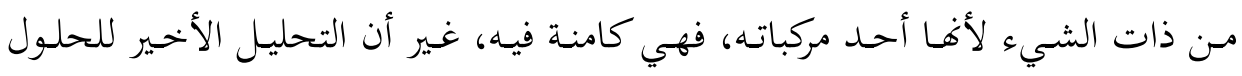

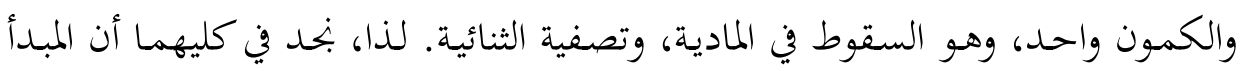

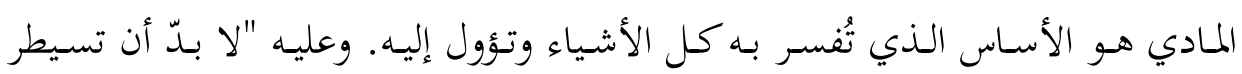
الواحدية الماديـة؛ وإن ظهرت ثنائيات فهي مؤقتـة يتم محوهـا في فاية الأمر وفي التحليل الأخير." الواحدية

ولما كانت المرجعية الكامنة مرجعية مادية، فإها تقدِّم رؤية مادية لكل شيء؛ للطبيعة

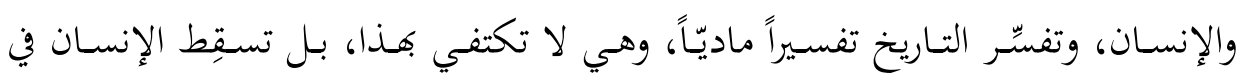
متتالية مادية، فيصبح مقولة مادية ويمارس وجوده وفق رؤية مادية، ومنه فإنان الطبيعة عالم

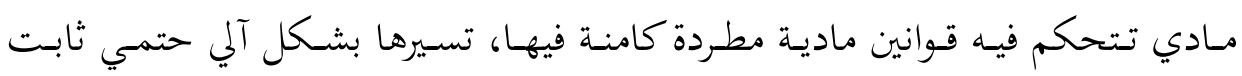

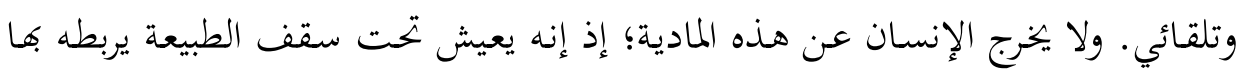

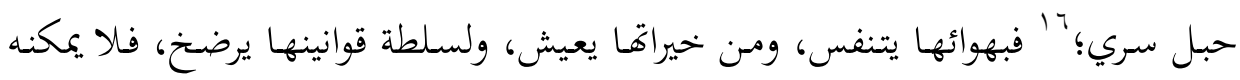

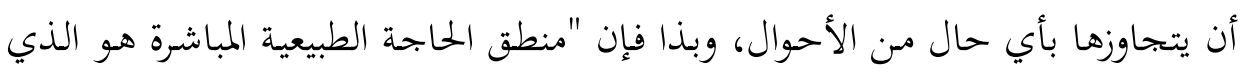

§' المسيري، الموسوعة، مرجع سابق، مج ا، صعـ هـ انظر أيضاً:

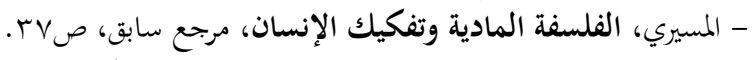

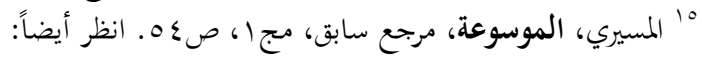

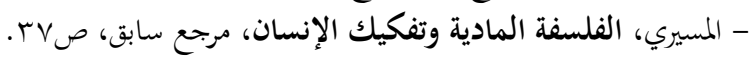

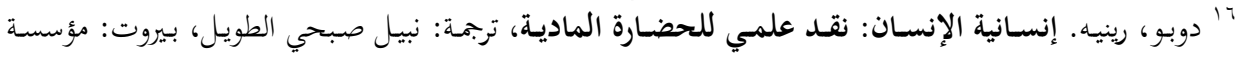


يتحكم في الأخلاق الإنسانية تماما مثلما تتحكم الجاذبية في سقوط التفاحة، ولذا تنادي المذاهب الأخلاقيـة الماديـة بـأن الشيء الوحيد الذذي يجـدر بالإنسـان أن يسعى إليه هـو الحيرات المادية التي بتود بها الحياة، والشيء نفسه ينطبق على المعايير الجمالية، فالشعور

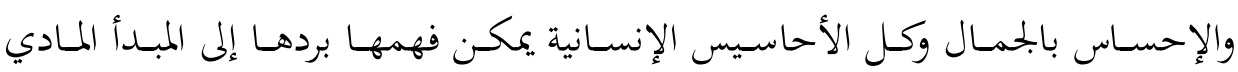

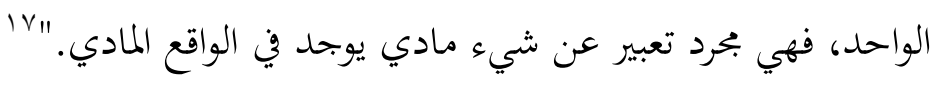

وكـذلك الحـال بالنسـبة إلى تفسـير التـاريخ؛ فهـو نتيجـة حتميـة للظـروف الماديـة

والاقتصادية، فتطور الإنتاج في كمّهـ وكيفه ووسائله، هـو سلم تقويم الحضـارة في تطورهـا

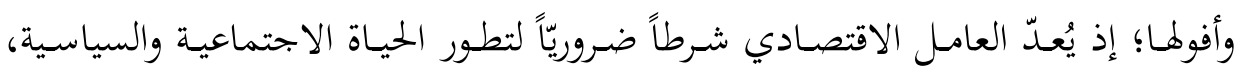
وحتى الفكرية والثقافية.

ولماكانـت المرجعيـة الكامنـة تتسـم بالواحديـة الماديـة؛ أي توحّد الإنسـان والطبيعـة

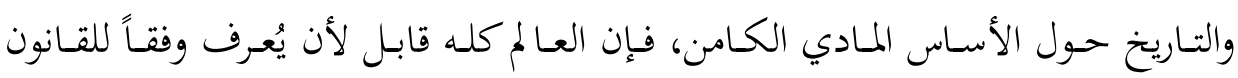

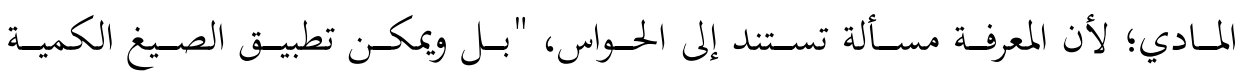

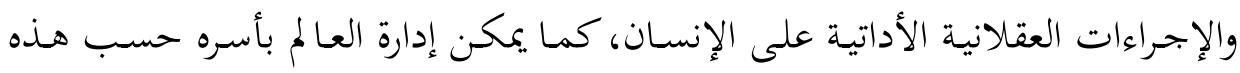

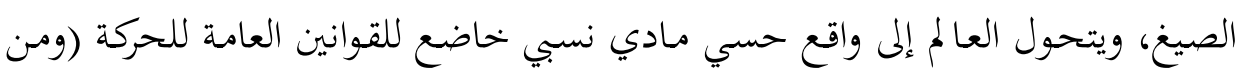
تم قابـل للقيـاس والـتحكم الهندسـي والتنمسيط) وإلى مـادة اسـتعمالية يمكـن توظيفهـا

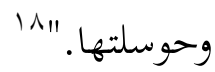

\section{ثانياً: التجاوز وتركيبية الإنسان}

يتناول المسيري مفهوم "المرجعية المتجاوزة" بمعنى المرجعية التوحيدية، التي بتعل الإله

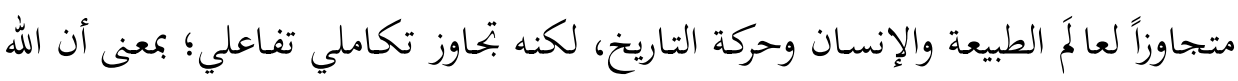
غير منفصل عن الكون كلية، وإنما هو بتحاوز استعلاء يضع مسافة بينية بين الإله الحنالق سبحانه ومخلوقاته، هذه المسافة هي التي تحفظ للإنسان قيمته ومكانته في الكون. 
إذا كانت أعمال المسيري عن المرجعية الكامنة تتمثّل في تحليله الظاهرة الغربية، التي

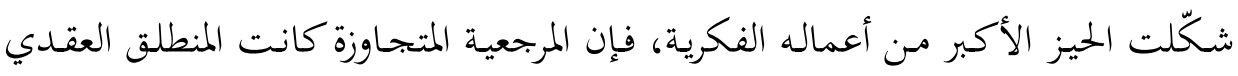

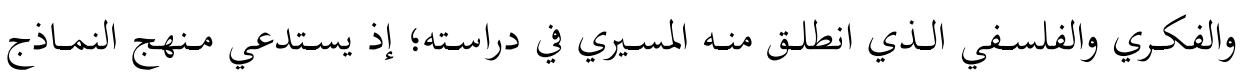

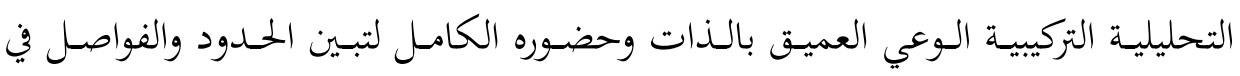
دراسة الآخر، ولتكون الدراسـة أكثر تفسيرية مـن غير تحيز للأنـا أو الآخـر. لـذا، يـأتي حديث المسيري عن المرجعية المتجاوزة في غالب أعماله عَرَضاً، لإضفاء تفسيرية أكثر في تحليل المرجعية الكامنة؛ إذ بنحده يفصح عن مرجعيته التوحيدية في ديباجـة معظم كتبـه، خاصة تلك التي تتطرق إلى الحضارة الغربية بشكل مباشر.

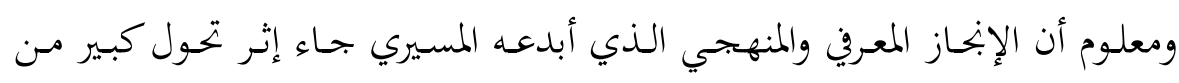

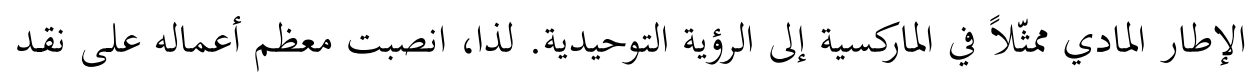

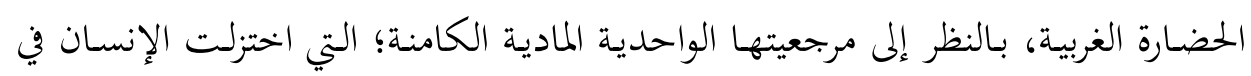

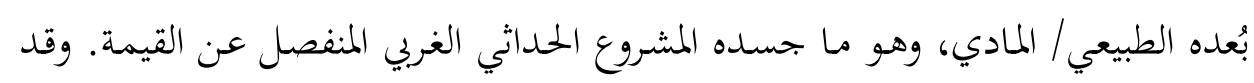

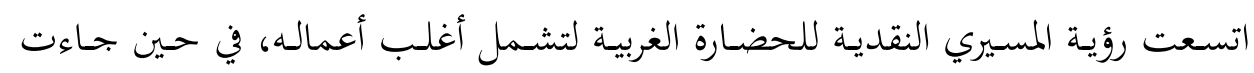
المرجعية المتجاوزة والثنائية الفضفاضة وتركيبية الإنسان والإنسانية المشتركة، بوصفها إطاراً مرجعيّاً لأعماله ومشروع حضاري هو في طور التأسيس، فما الرؤية التي يقدمها المسيري

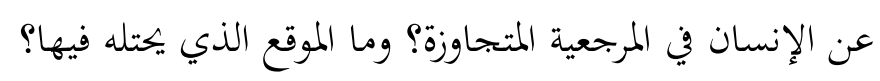

\section{ا ـ التجاوز والثنائيات الفضفاضة:}

يتخذ التجاوز بُعداً دلايسّاً واسعاً في المرجعية التوحيدية، يُحدد الأبعاد الكلية والنهائية

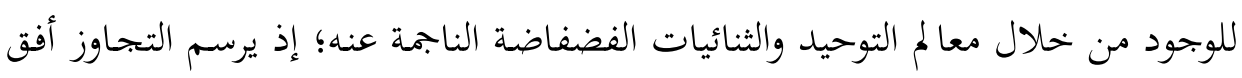

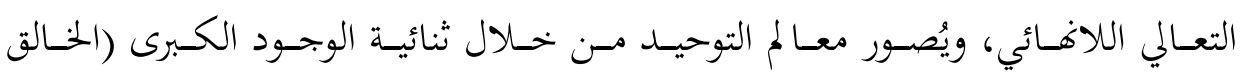

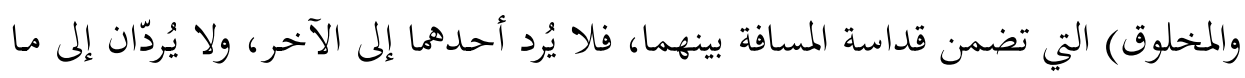
دوغما، وفي باقي الثنائيات الفضفاضة التي تعد المسافة مكوناً رئيساً فيها. وتتضح فلسفة التجاوز عند المسيري في جدل الله والإنسان والطبيعة والعلاقات التي

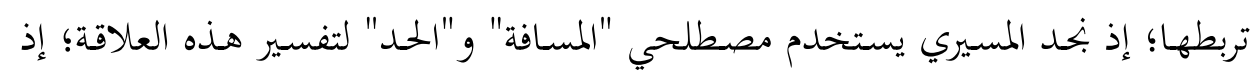




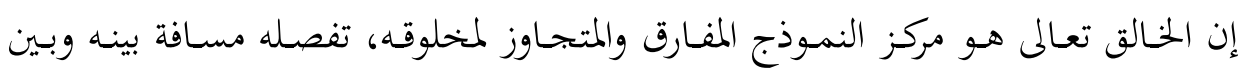

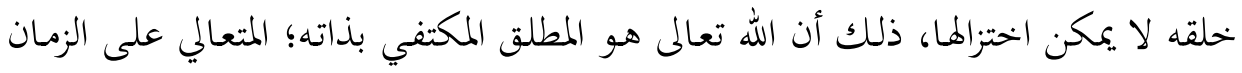

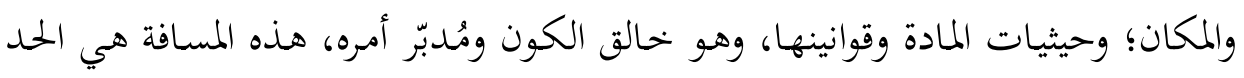

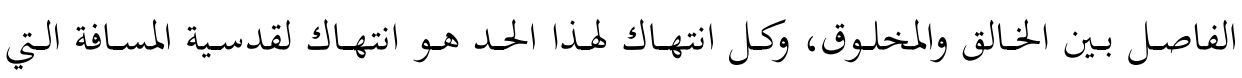

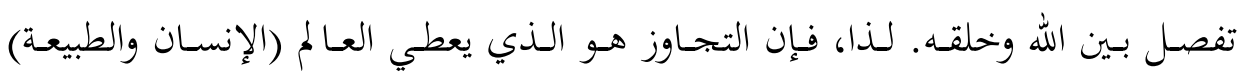

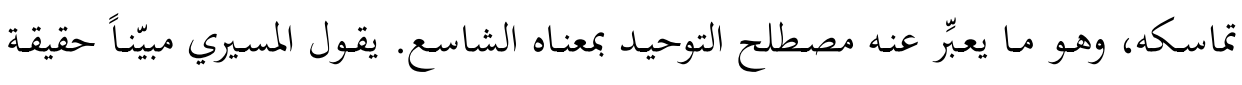

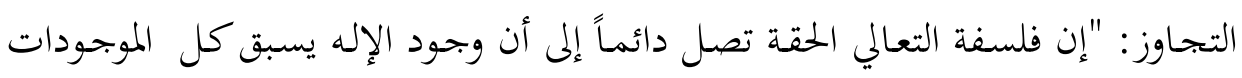

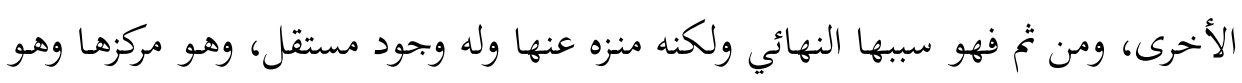

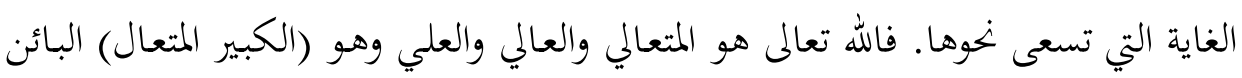

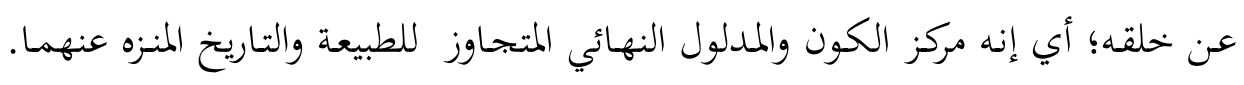

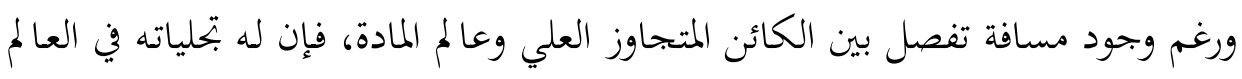

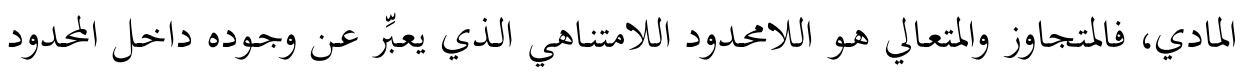

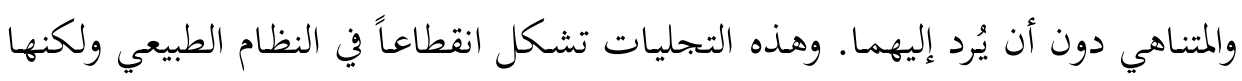

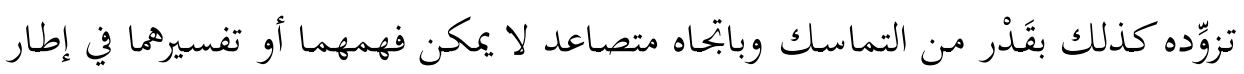

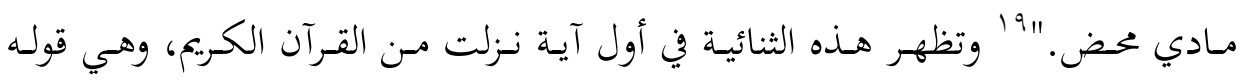

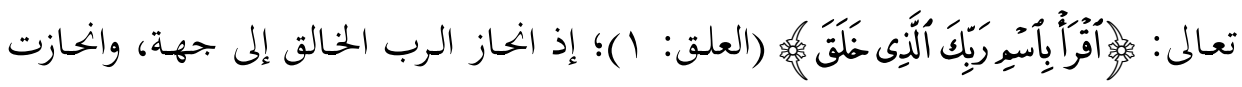

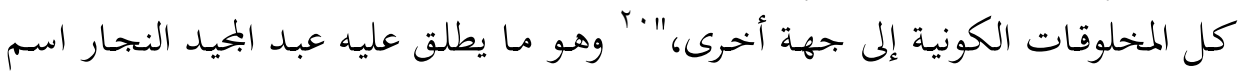

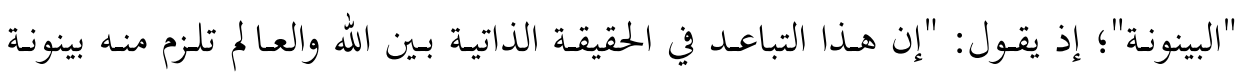

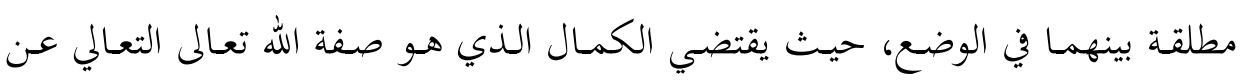

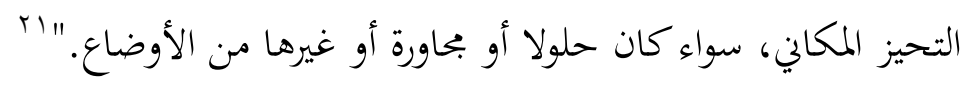

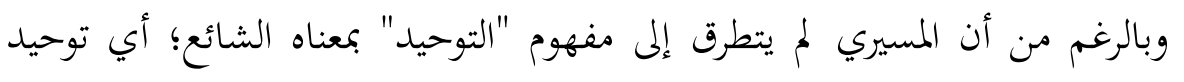

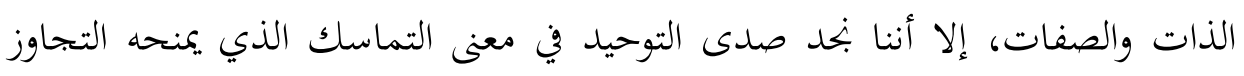

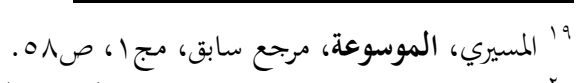

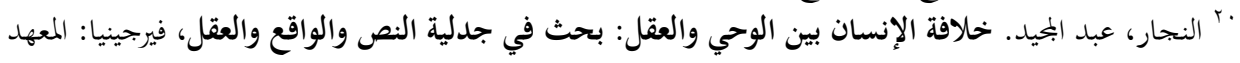

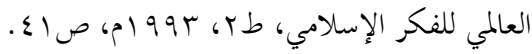

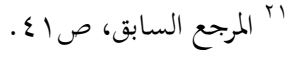


للكون؛ إذ ينتظم الكون ضمن بحموعة من السنن التي تضبط حركته، ويؤكد تفاعلها وتكاملها وجود جانب متجاوز فيها على الرغم من كونه خفيّاً، وهو ما يسميه علماء العقيدة دليل النظام ودليل الحركة في الكون المادي (الطبيعة)، اللذيْن يشيران إلى المرجعية الإلهية لمذا الكون، بل إن خضوع الكون لله يتخذ معنى العبودية له، ويظهر ذلك في قوله

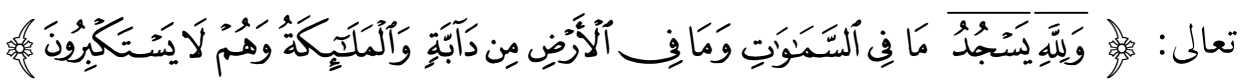

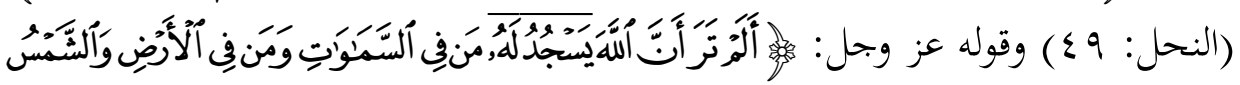

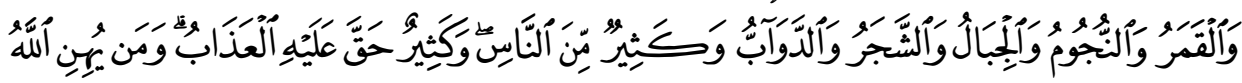

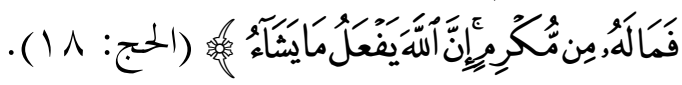

ويمنح التجاوز الإنسانَ تماسُكَه أيضاً من خهلال استقاله عن الطبيعة، على الرغم

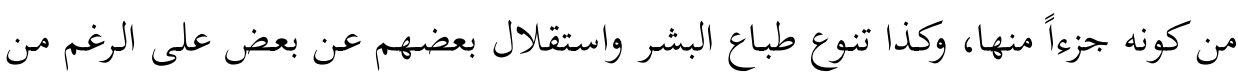
انتمـائهم إلى الجـنس البشـري، وحاجـة بعضهـم إلى بعض، بمـا يؤكـد الجحانـب الفـردي في الإنسـان إضـافة إلى الجحانـب الجمــاعي فيـه. ولإدراك عمـق التجــاوز والتوحيـــ في كلتـا الظاهرتين (الطبيعية والإنسانية)، يستخدم المسيري النموذج المركب الذي يصدر أساساً عن الإيمان بالمرجعية التوحيدية المتجاوزة، وبوساطته يمكن أن ندرك جوهر التجاوز في كلتا الظـاهرتين. يقـول المسـيري: "المطلـق المكتفي بذاته الـذي يتجـاوز كـل الأفراد والأشسياء

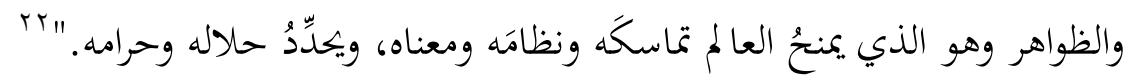
ويحلل المسيري معنى التماسك باستخدام النموذج التركيبي في كونه يتجلّى في مظاهر

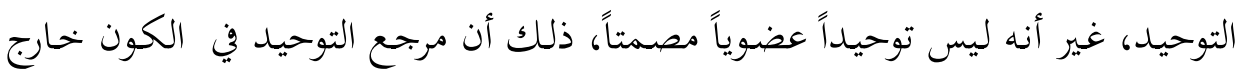
عنه وليس كامناً فيه؛ إذ تستقل الظواهر بعضها عن بعض، مع أنها تُرد في كلها إلى ناظم

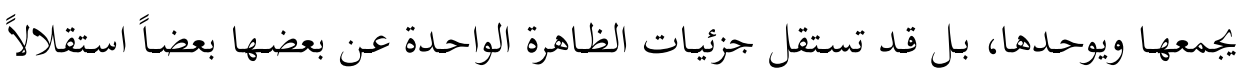

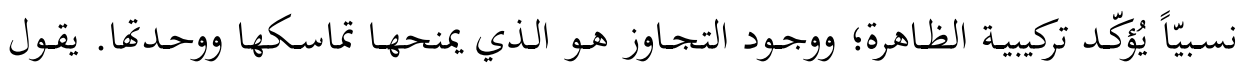

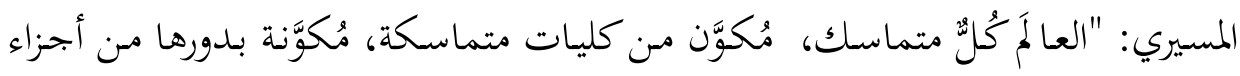
غير مترابطة بشكل صلب وغير متجانسة بشكل كامل، ومع هذا فهي أجزاء متماسكة، بـاء 


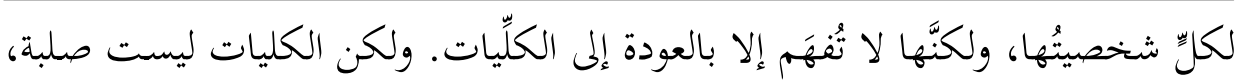

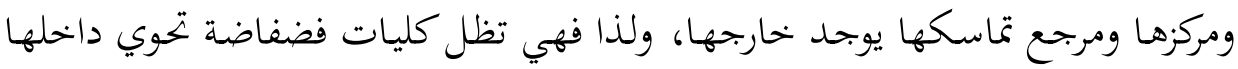

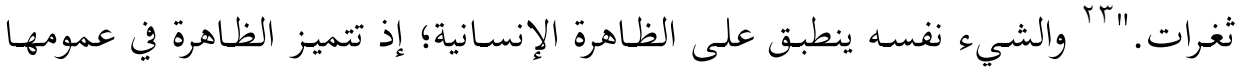

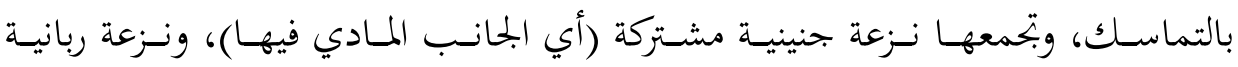

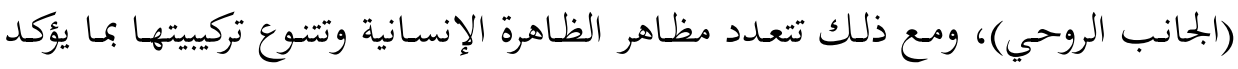

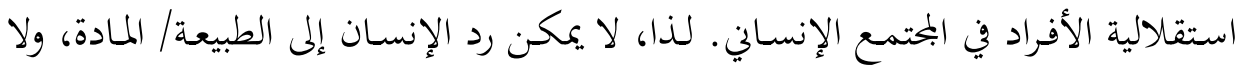

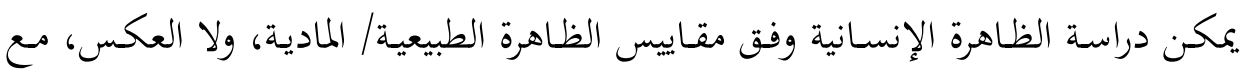

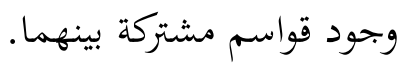

وتأسيساً على ما سبق، فإن فلسفة التجاوز لا تُفهم إلا من خحلال معاني الثنائيات الفضفاضة، وما يمكمها من علاقة فضفاضة هي الأخرى.

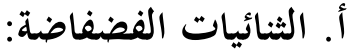

يستخدم المسيري الثنائيات الفضفاضة بوصفها أداة تحليلية لتحليل مضامين المرجعية

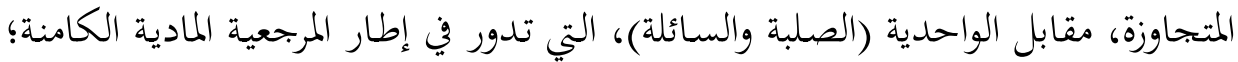

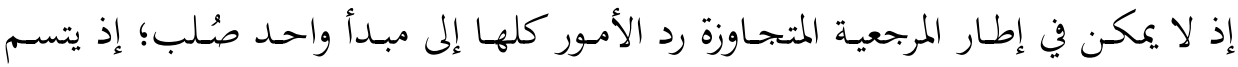

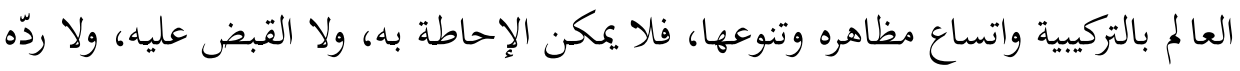

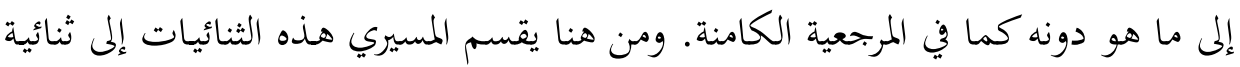

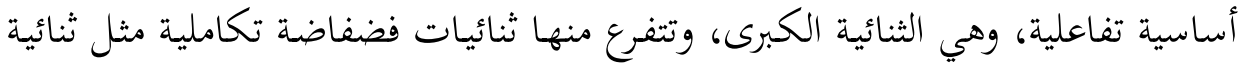

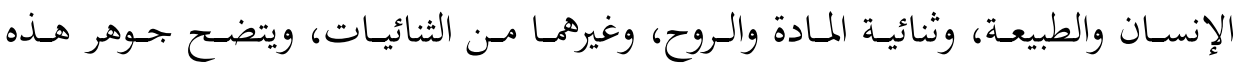
الثنائيات في تفاعلية الثنائية الأساسية وتكاملية الثنائيات المتفرعة منها.

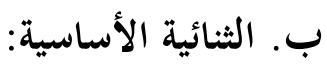

الثنائية الفضفاضة الأساسية هي ثنائية الخالق والمخلوق، وهي ثنائية تفاعلية تقوم

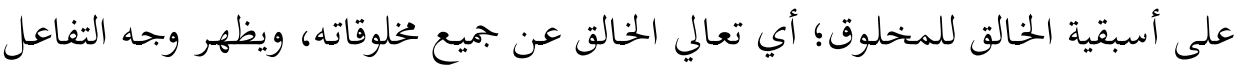




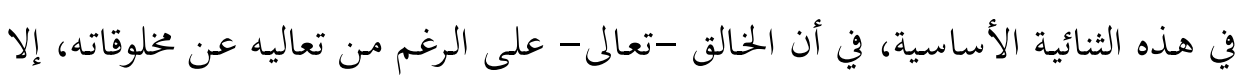

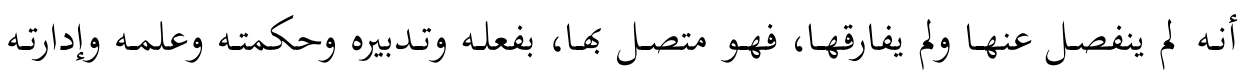

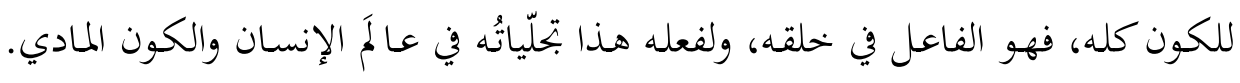

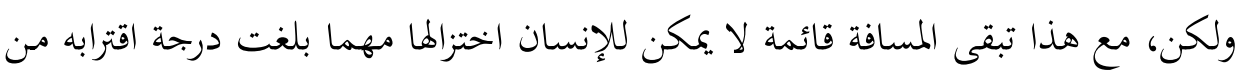

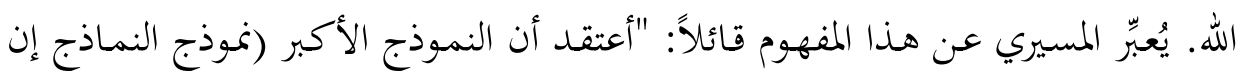

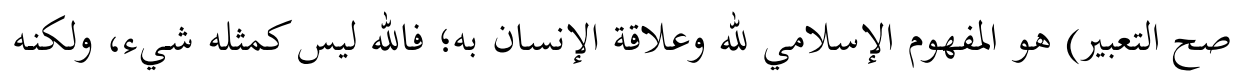

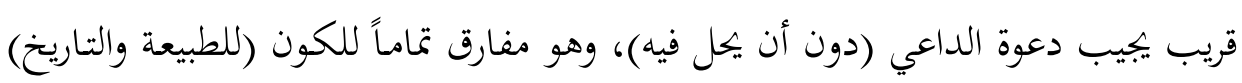

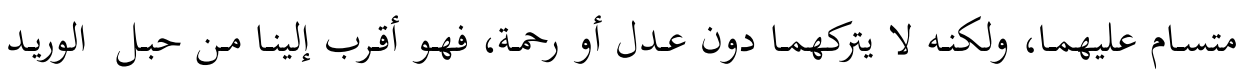

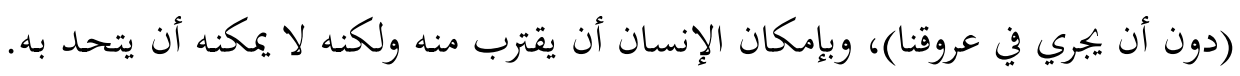

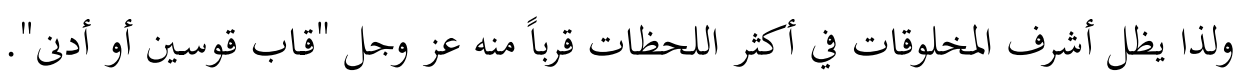

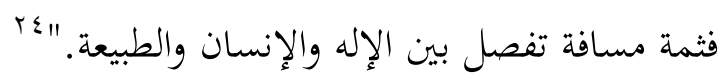

أما الطرف الثاني في هذه الثنائية (المخلوق)، فهو متفاعل مع الخالق تفاعل خضوع

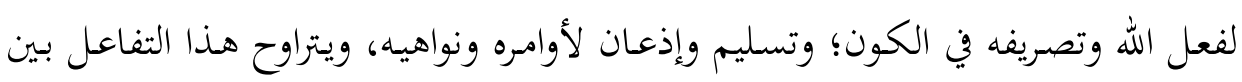

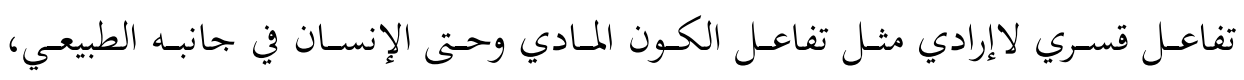

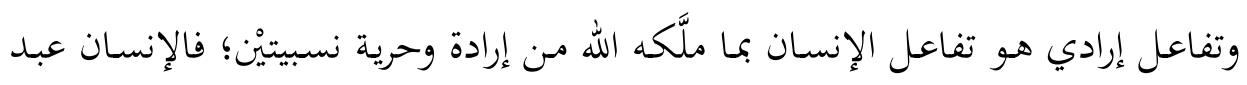

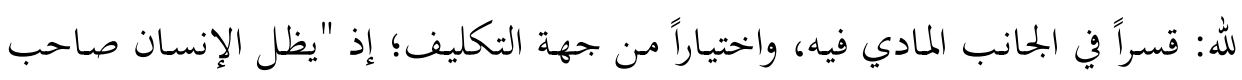

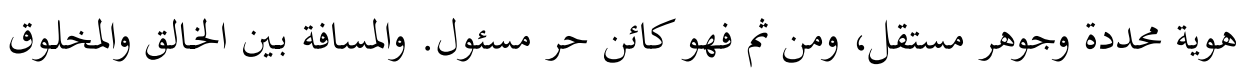

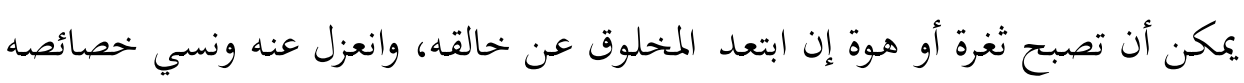

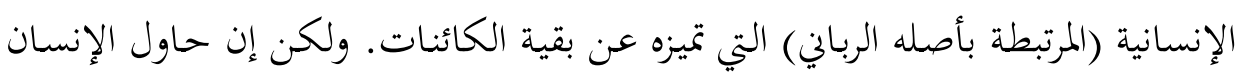

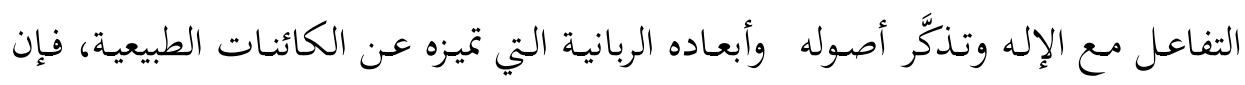

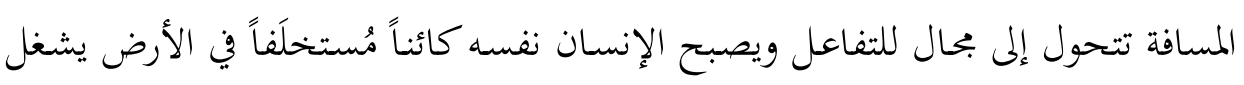

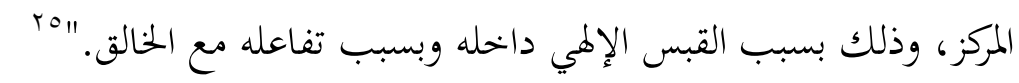

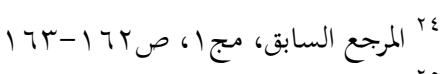

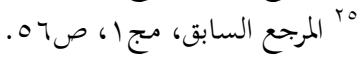


وتتفرع من هذه الثنائية الأساسية ثنائيات فضفاضة أخرى، أهمها ثنائيات الإنسان

والطبيعة.

\section{ت. الثنائيات الفضفاضة التكاملية:}

تتفـرع مـن الثنائيسة الفضفاضـة الأساسية ثنائيـات أخـرى فرعيـة عديـدة تتميـز بأهـا

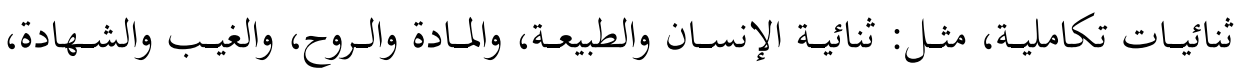

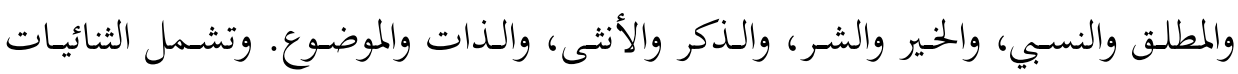

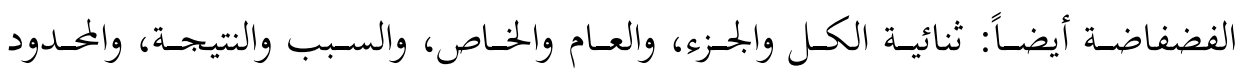

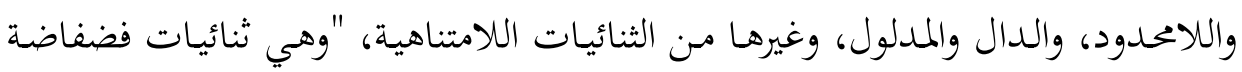

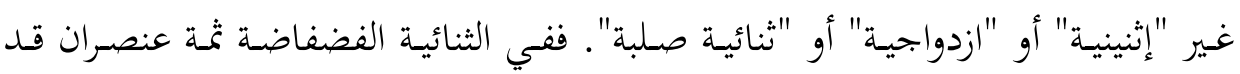
يكونان متكافئين أو غير متكافئين، ولكنهما مع هذا يتفاعلان ويتدافعان، أما في الإثنينية

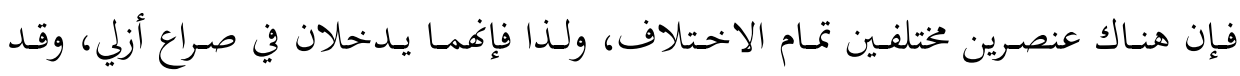

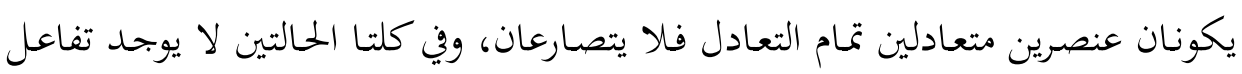

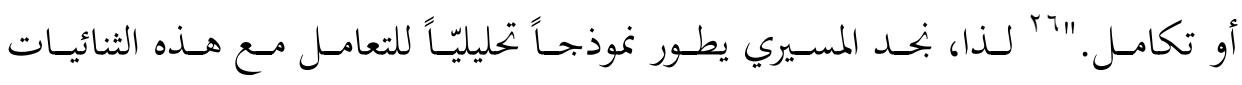

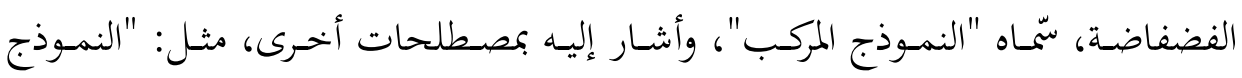

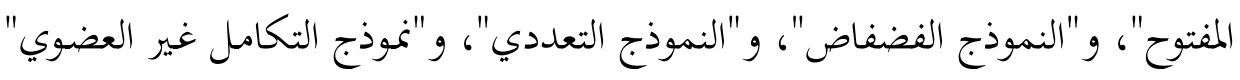

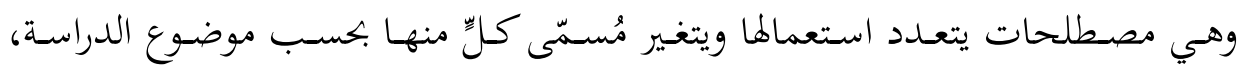
ويقابلها النموذج الاختزالي الذي يختزل الظواهر في مبدأ واحسد. للذا؛ يستعمل المسيري غالبـاً مصـطلح النمـوذج المركـب للدلالـة علـى وجـود عناصـر متداخلــة مركبـة للظـاهرة

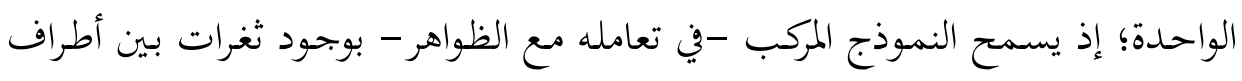

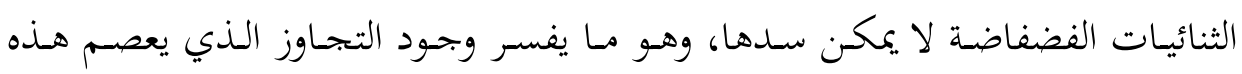

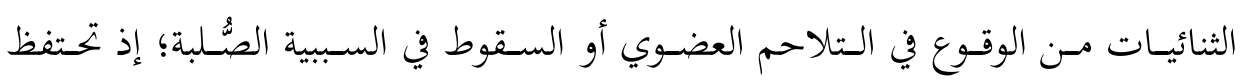
أطراف الثنائيات باستقلالها النسبي على الرغم من اتساقها وانتظامها في إطار كلي، وأهم

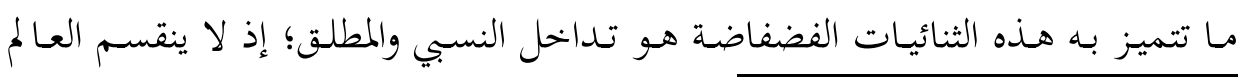

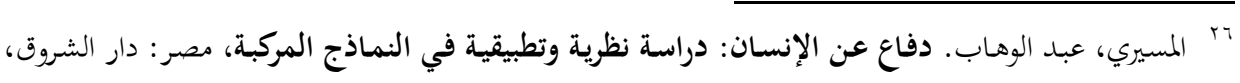

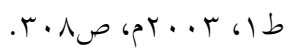


بشكل حساد إلى نسبي ومطلق، بـل يتفاعل النسبي والمطلق في الظواهر كلها ويتكامـل. يقول المسيري: "لا ينقسم العالم بشكل حاد إلى مطلق ونسبي، فالمطلق النهائي الوحيد

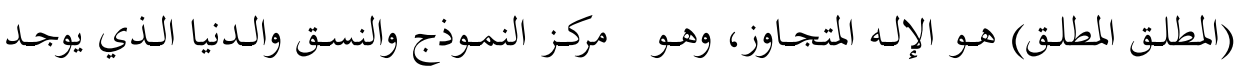

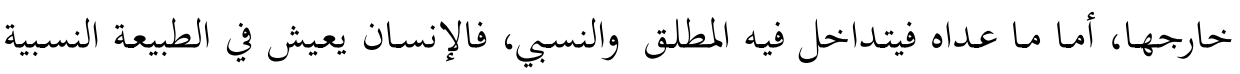

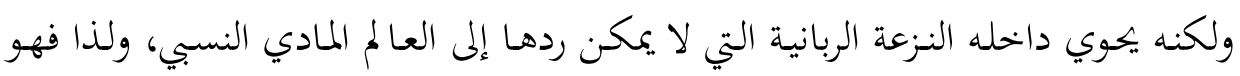

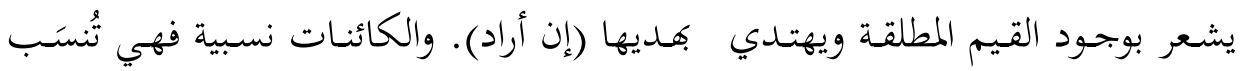

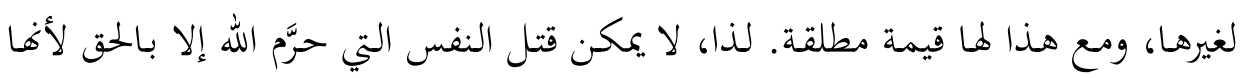
مطلقة، ومن قَتَل نفساً بغير حق فكأنما قتل الناس جميعاً. وأقل المخلوقات في الكون هي في لئي

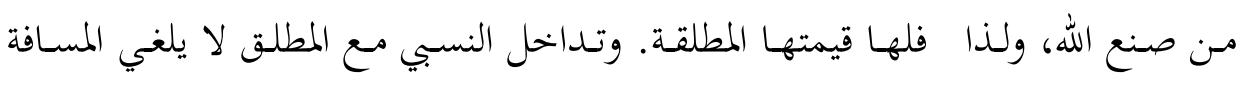

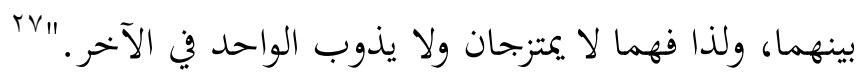

ومن هنا يتحدث المسيري عن مفهوم النسبية الإسلامية في الوعي الإنساني للوجود، فـالكون خلـق الله، والـوحي خطـاب الله، فـالله هـو المطلـق (في خلقـه ووحيـه)، والـوعي اللهي الإنساني بالكون والوحي نسبي؛ وفي ذلك يقول: "ويمكننا الحديث عن النسبية الإسلامية باعتبارها نسبية تنصرف إلى خطاب الخالق، فنحن نؤمن بأن ثمة مطلقات فهائية لا يمكن وفئن

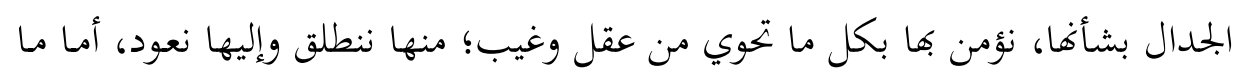

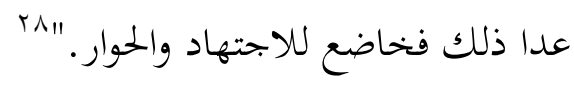

وتتجلّى تكاملية هذه الثنائيات في أفها -على الرغم من استقلالها- تنتظم في إطار

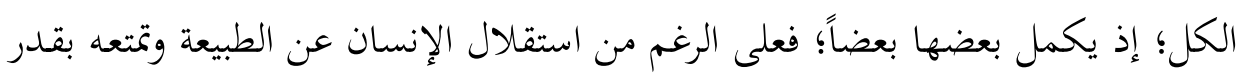

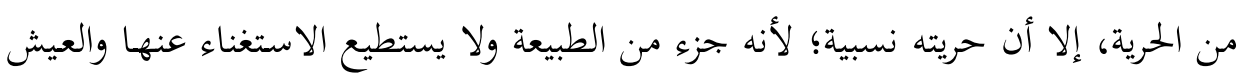

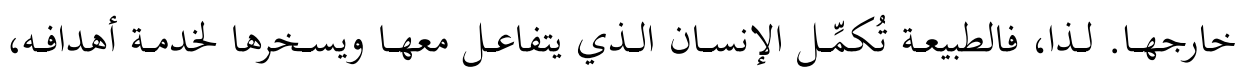
ويتجلّى تكامل الثنائيات الفضفاضـة بشكل أكبر في ثنائية الذكر والأنثى؛ إذ يستحيل

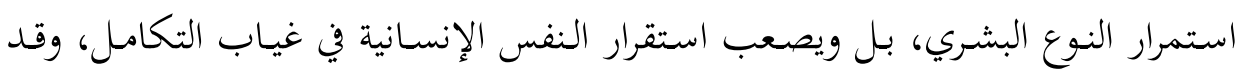

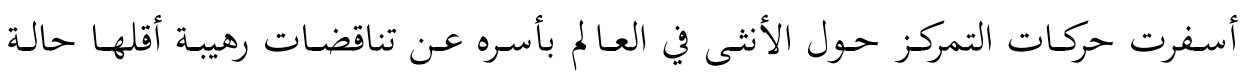

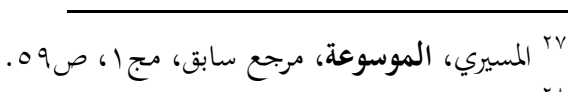

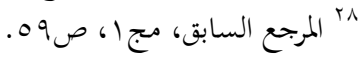




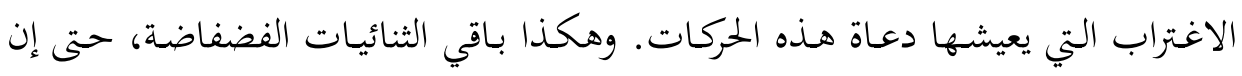

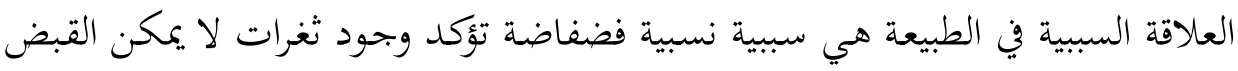

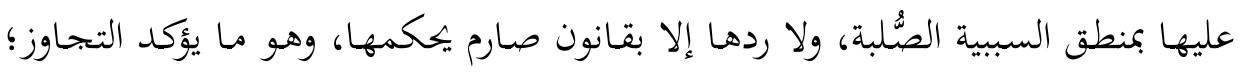
أي احتكامها إلى مطلق خارج عنها.

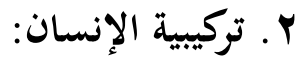

ترسم لنا فلسفة التجاوز خريطة إدراكية تُحِّدد بحال الرؤية وأفقها؛ من خلال ثنائيات

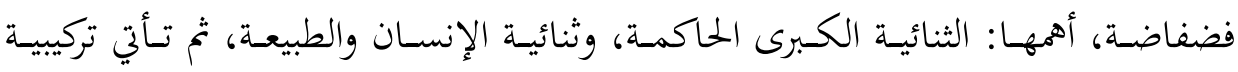

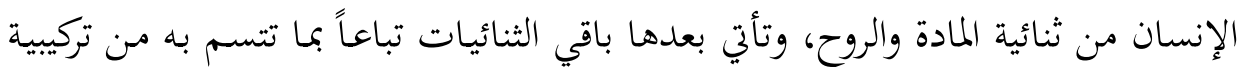

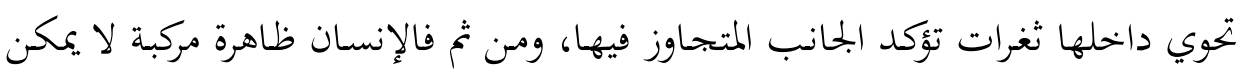

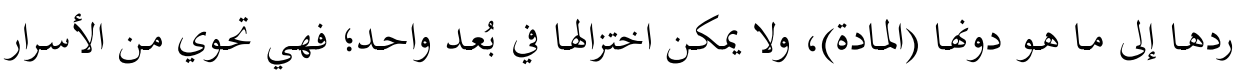

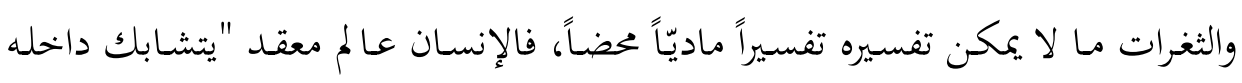

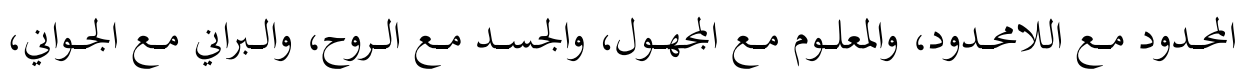

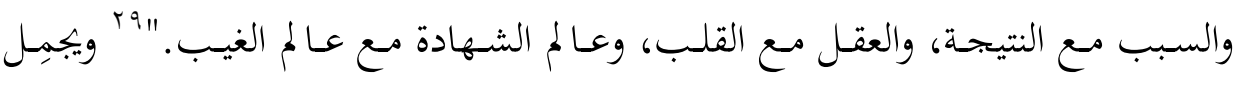

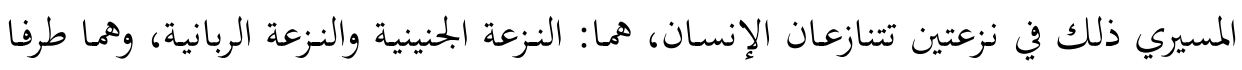

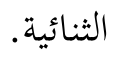

فالطرف الأول في الثنائية هو الجانب الطبيعي، أو ما يسميه المسيري النزعة الجنينية،

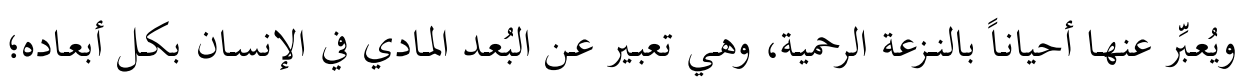

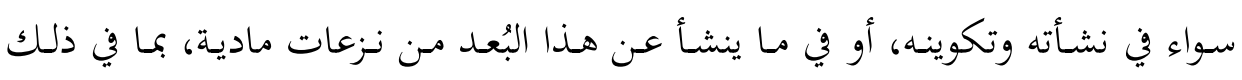

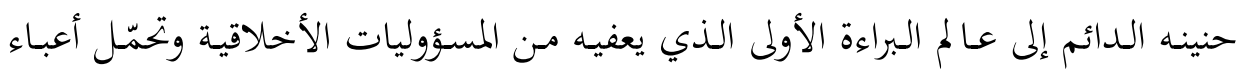

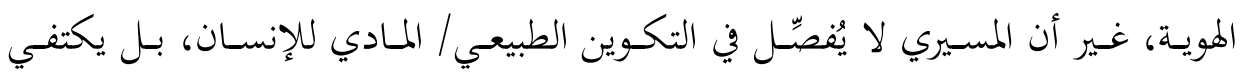

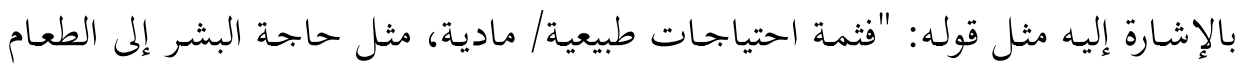

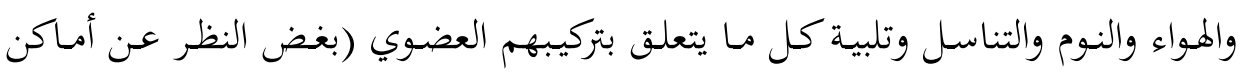

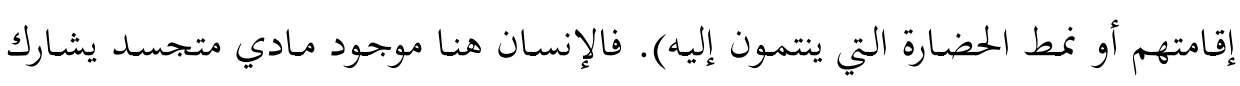

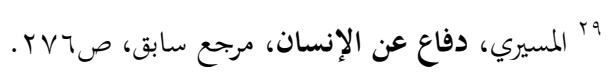


بقيـة الكائنـات في بعض الصـفات، فمـن حيـث هـو جسـم، يخضـع الإنسـان للقـوانين الطبيعيـة وضـرورات الحيـاة العضـوية؛ إذ تسـري عليـه وعلى بقيـة الكائنـات بحموعـة مـن الآليات والحتميات، لذا يمكن رصد هذا الجحانب من وجوده من خهلال النماذج المستمدة

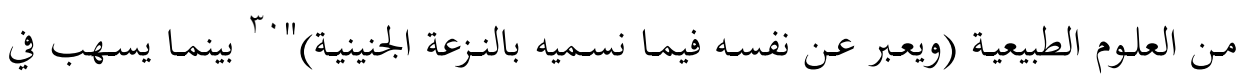

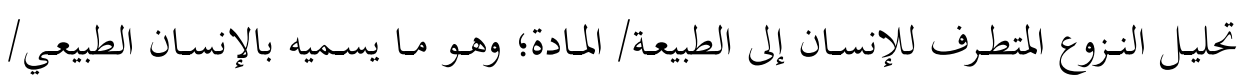

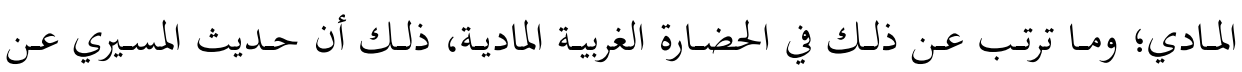
تركيبية الإنسان جاء في إطار نقده الحضارة الغربية ومرجعيتها المادية الكامنة، وما يتطلبه ذلك مـن ضرورة الرجوع إلى المرجعية المتجاوزة بين الحين والآخر، لإجراء مقارنة بينهما؛

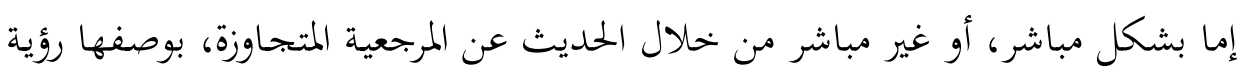

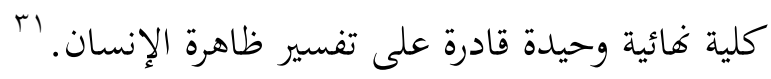

أما الطرف الثاني في الثنائية فهو البُعد الروحي، أو ما يسميه المسيري النزعة الربانية أو القبس الإلهي، وهو في تعريف المسيري: "ذلك النور الذي يبثه الإله الواحد المتجاوز في صدور الناس (بل في الكون بأسره)، فيمنحه تركيبيته اللامتناهية، ويولِّد في الإنسان

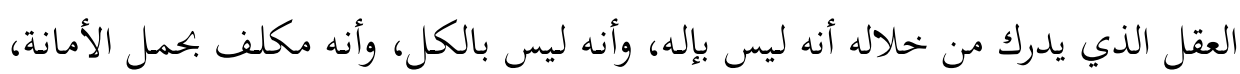

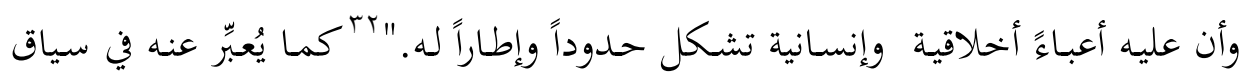
آخر بقوله: "فالإنسـان قد خلقـه الله ونفـخ فيه مـن روحهـ وكرَّمه واستأمنه على العالم

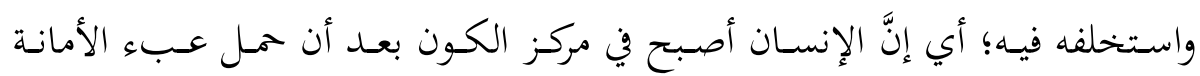

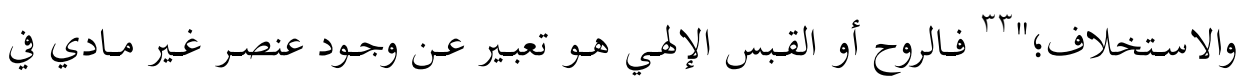
الإنسان ويمُثّل جوهر تركيبيته، ووجوده هو الذي يعطي الإنسان معنى التجاوز؛ سواء في

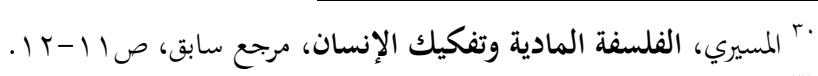

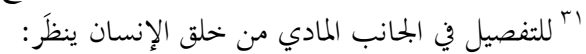

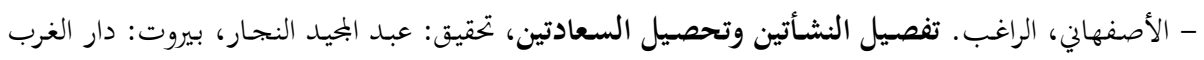

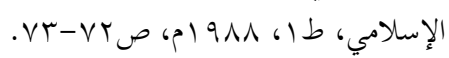

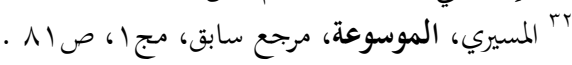

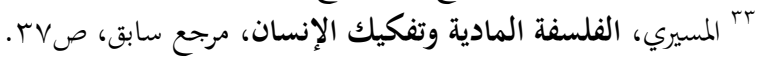




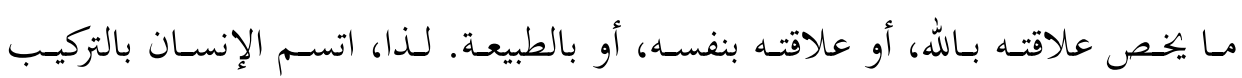

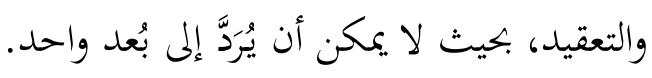

وقد فشلت الحضارة الغربية في تفسير الظاهرة الإنسانية، لإقصائها هذا البُعد الروحي

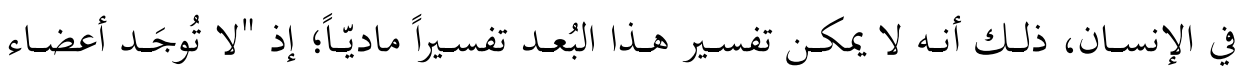

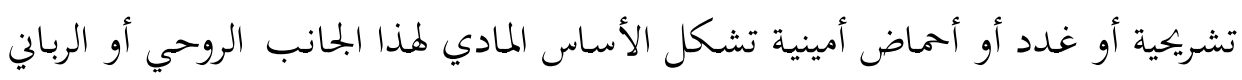

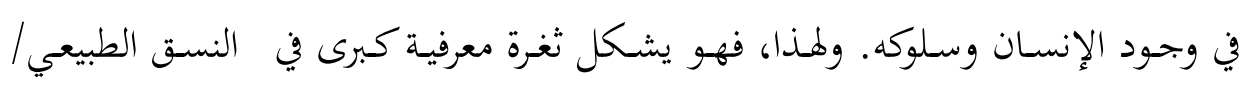

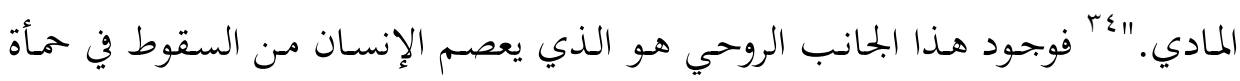

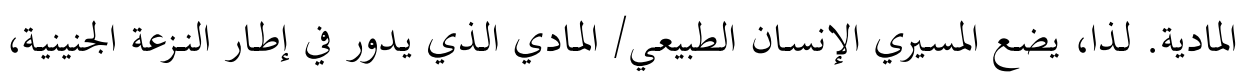

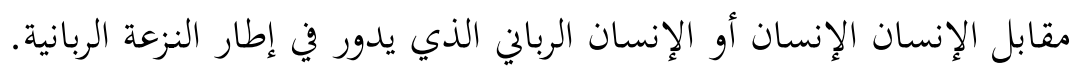

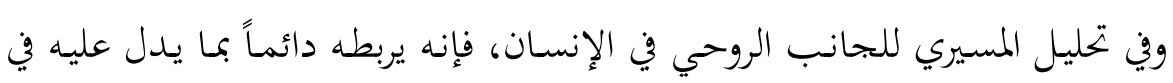

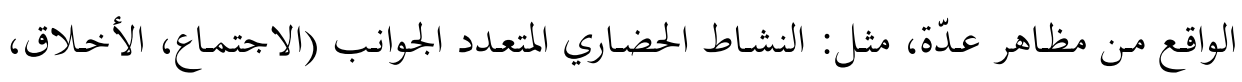

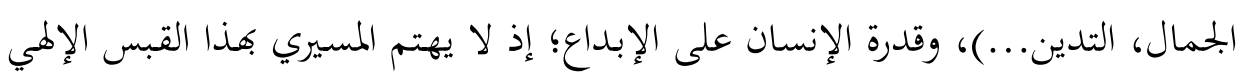

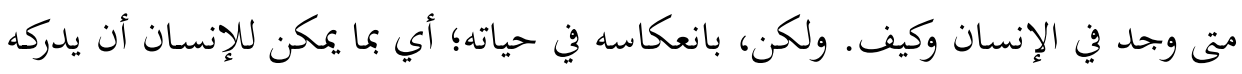

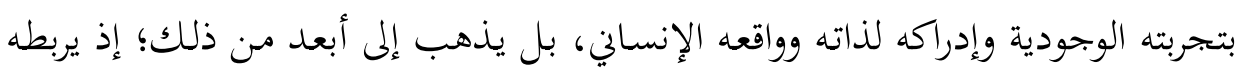

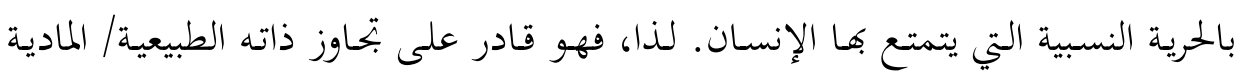

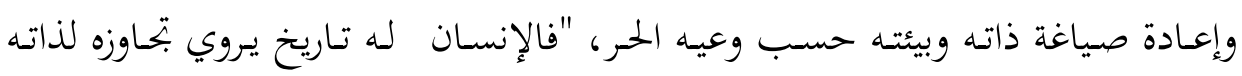

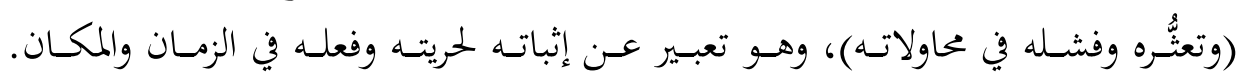

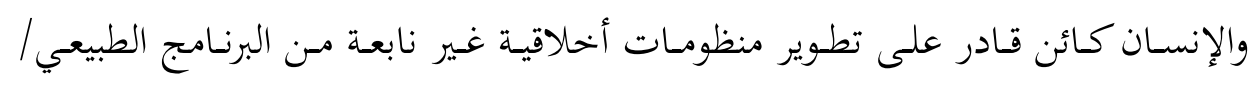

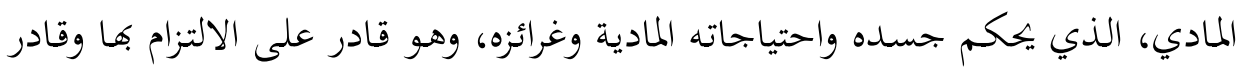

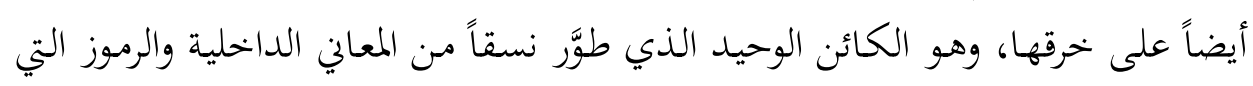

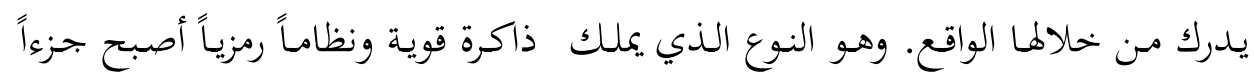

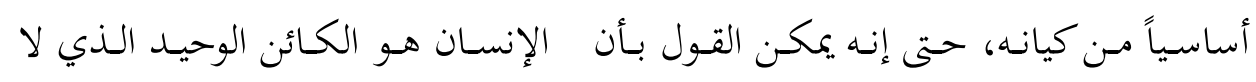

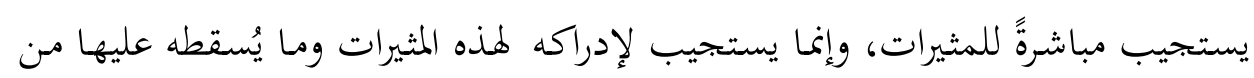


رموز وذكريات. والإنسان هو النوع الوحيد الذي يتميَّز كل فرد فيه بخصوصيات لا يمكن

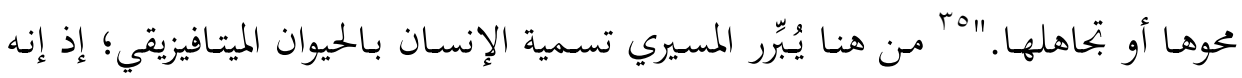
الكائن الوحيد القادر على طرح أسئلة وجودية "أنطولوجية" أو ما يسمى بالعلى الإنل الأولى. وإذا كان الجانب الروحي هو جوهر التجاوز في الإنسان ومـا يميز تركيبيته، فهذا لا

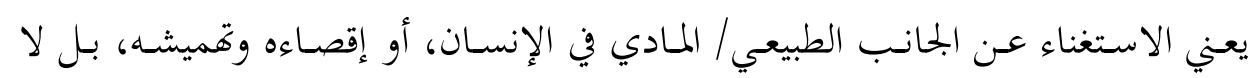

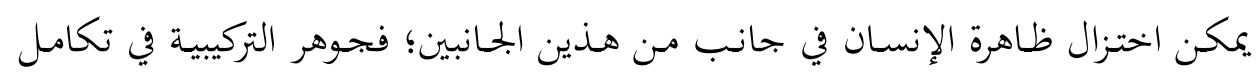

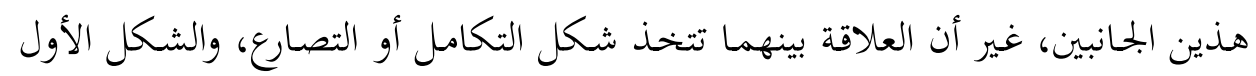

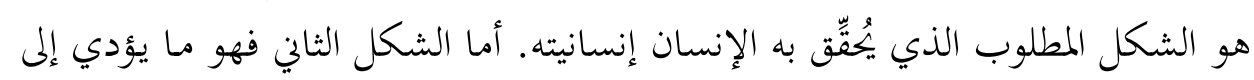
السقوط في الواحدية؛ سواء أكانت واحدية مادية أم واحدية روحية.

ويؤكد المسيري في إطار نقده إقصاء الحضارة الغربية هذا الجانب، أفها محاولة فاشلة لإخفاء عنصر مستقر في لا وعيهم؛ أي إن الجانب الروحي فطري في الإنسان لا يمكن أن يستأصله من ذاته، وهو ما يعبّر عنه بالإله الخفي.

\section{- فطرية الجانب الروحي أو الإله الخفي:}

بالإضافة إلى إيمان المسيري بتركيبية الإنسـان وتحليله لثنائيته الفضفاضـة، فإنه يطرح مصطلح الإله الخفي للتعبير عن فطرية التدين. ففي نقده الحضارة الغربية التي ترفض - في إلي

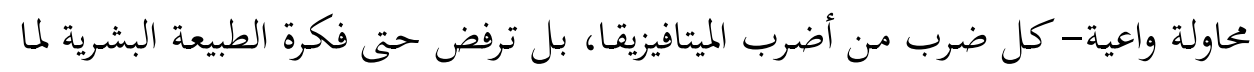

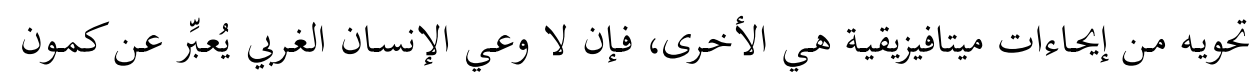

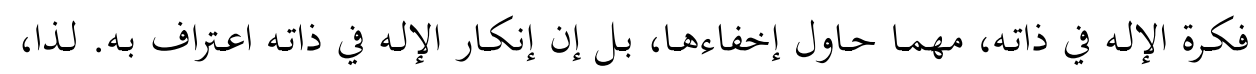

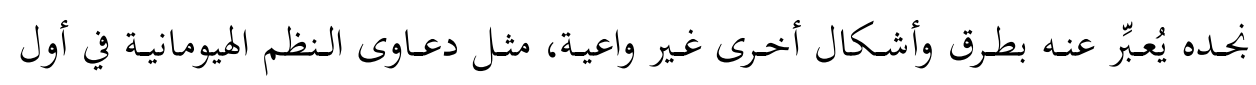

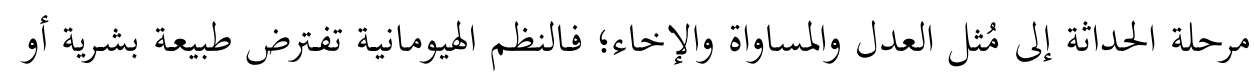

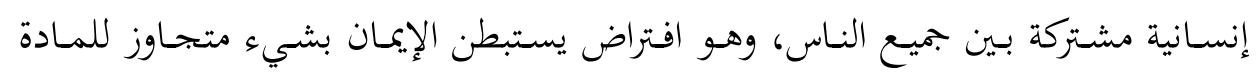

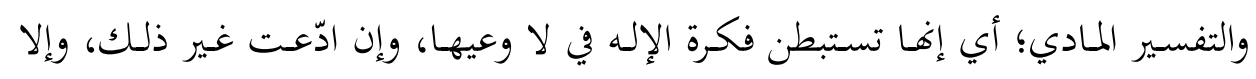

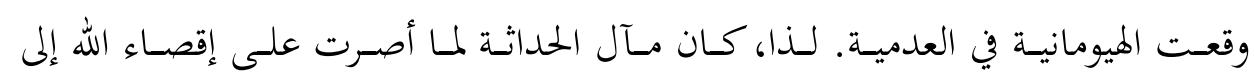


العدميـة. بـل يـذهب المسـيري إلى أن الإيمـان بالأطبـاق الطـائرة -وهـو إيمـان شـائع بـين

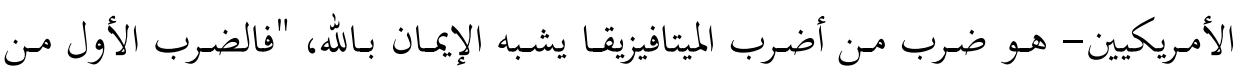

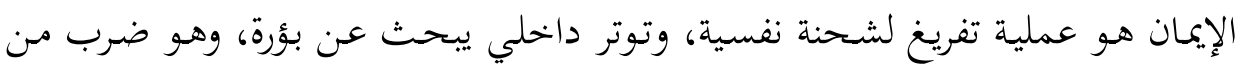

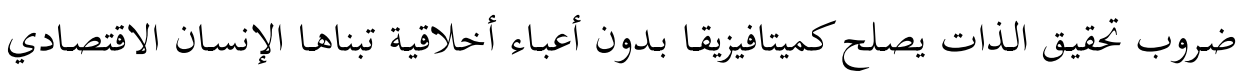
والإنسان النفعي الذي لا يؤمن إلا بالمادة ويجد صعوبة حقة في التسامي عليها وبتحاوزها،

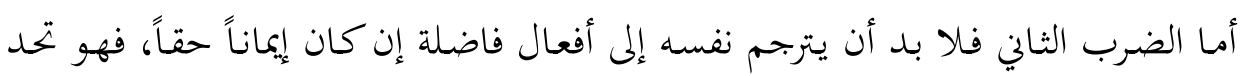

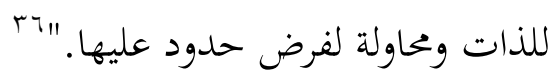

ويوجــد مصـطلح آخـر مـرادف لمصـطلح "الإلـه الخفـي" ودالّ عليـه؛ هـو مصـطلح

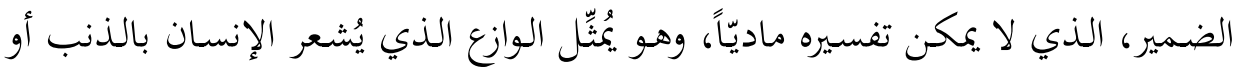

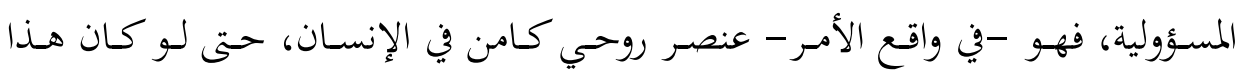

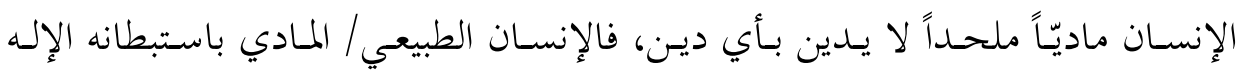

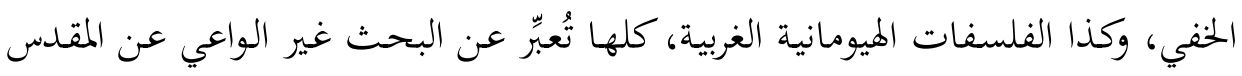

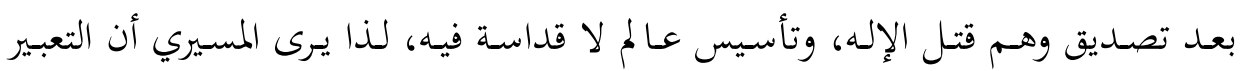
الدقيق عن فكرة موت الإله التي أذاعها نيتشه وتبنتها الحضارة الغربية؛ هو نسيان الإله. يقول المسيري: "ولو أردنا التعبير عن هذه الفكرة بالمصطلح الإسلامي لقلنا "نسيان الإله"

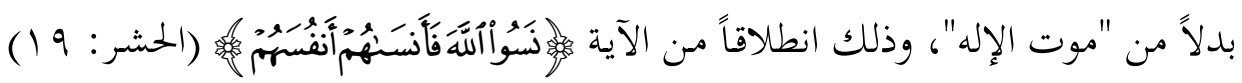

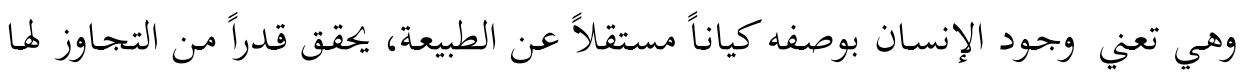
بسبب علاقته بالإله المتجاوز . فإن نسي الإنسان الله وظن أنه غير موجود، نسي نفسه

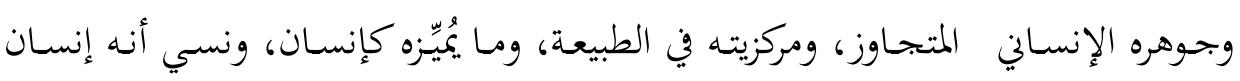

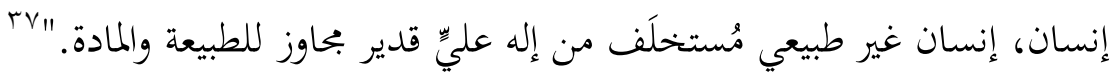
وبالرغم من تبني الحداثة الغربية لمقولة "موت الإله"، فبإن الإله الخفي ظل كامناً في ذات الإنسان الغربي، لذا ظهر في مرحلة الحداثة حديث عن حتمية الميتافيزيقا، بوصفها

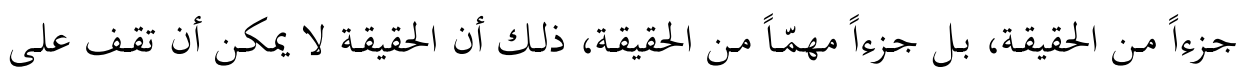


أرض المرجعية المادية المتحركة، "وقد أدرك نيتشه أن هـذا تعبير عن الإله الخفي، واختـار

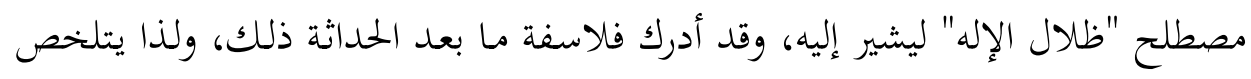

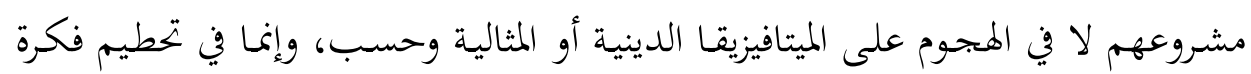

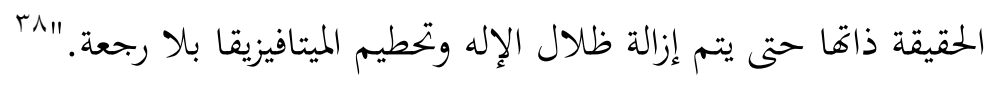

وإذا عدنا إلى المرجعية التوحيدية، فسنجد لفكرة الإله الخفي دلالة قوية تشير إلى

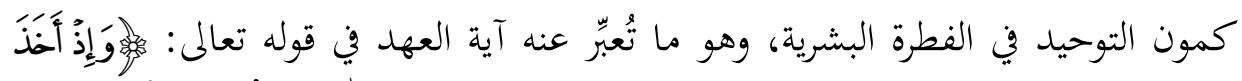

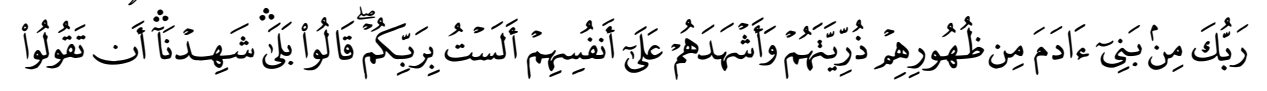

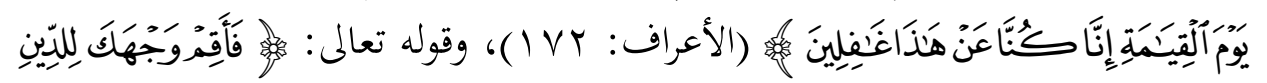

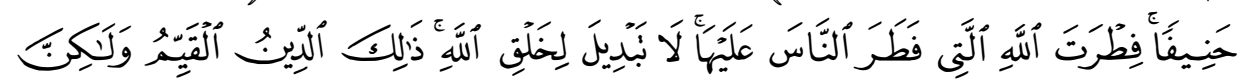

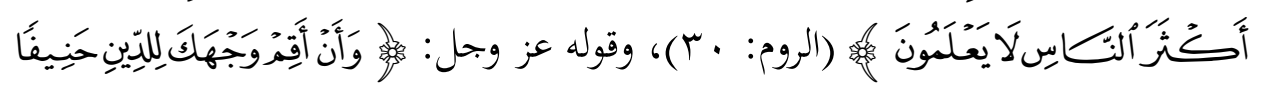

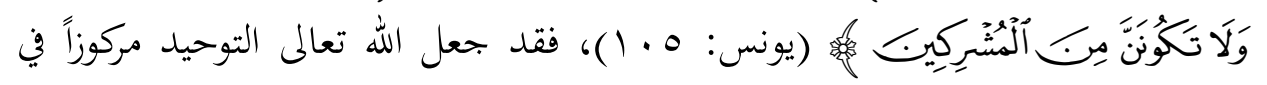
فطرة الإنسان؛ فهو فطرة الله التي فطر الناس عليها، ومنه فقد جُبل الإنسان على توحيد

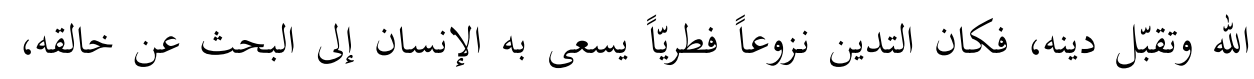

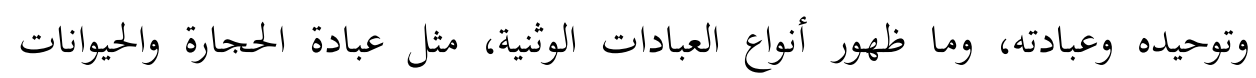
وتقديس البشر وغيرها، إلا تعبير عن سعي الإنسان إلى البحث عمّا يسميه المسيري

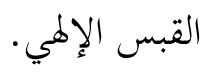

ففي الآيـة الثانيـة دلالـة على أن المقصـود بالحنيفيـة الفطرة، ودلَّت الآيـة الثالثة أن

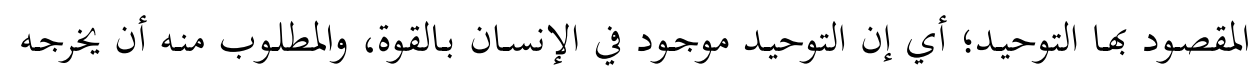

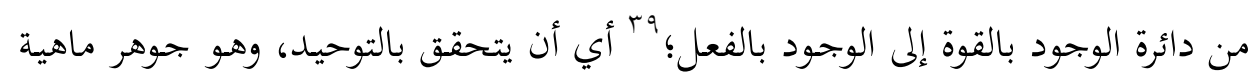

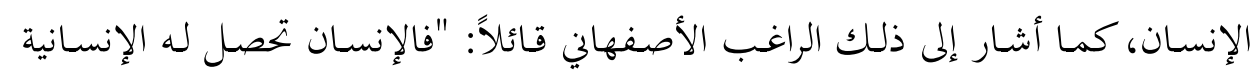

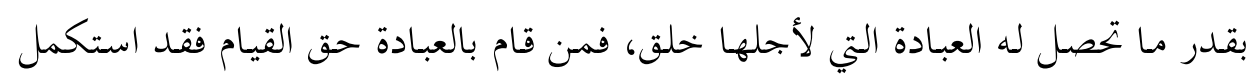

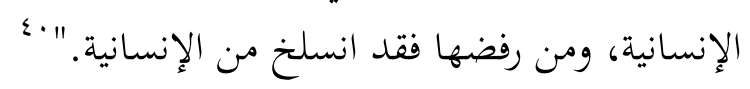

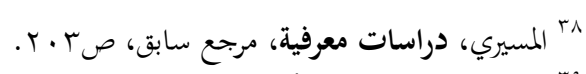

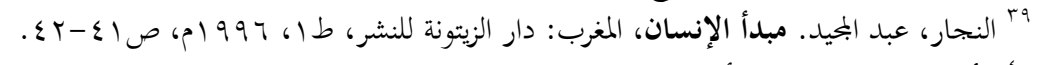

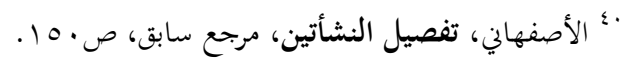




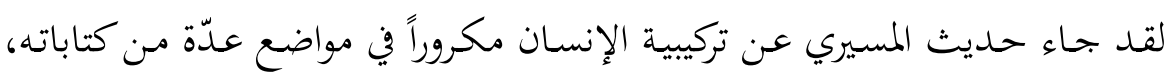

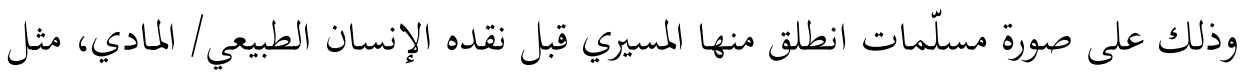

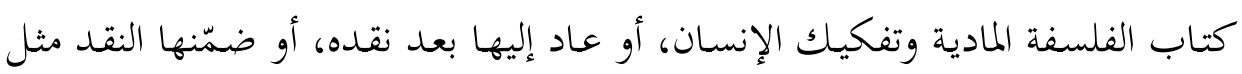

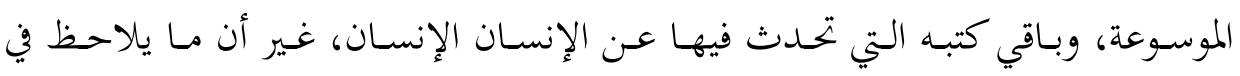

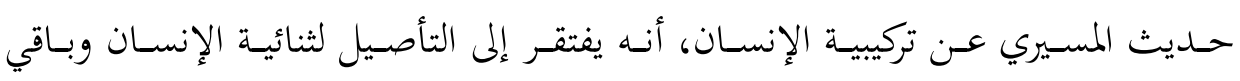

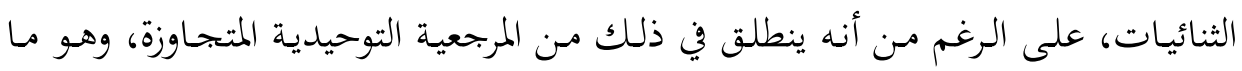

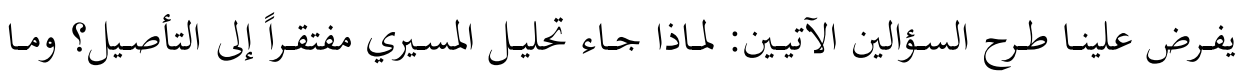

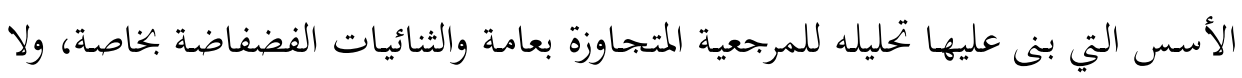

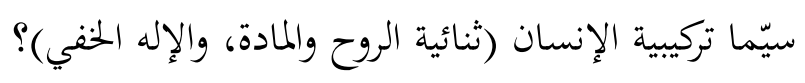

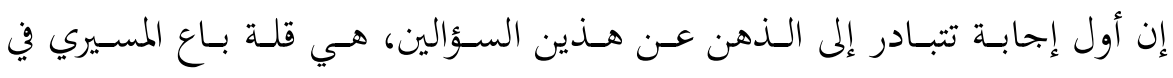

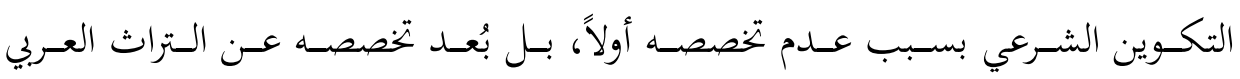

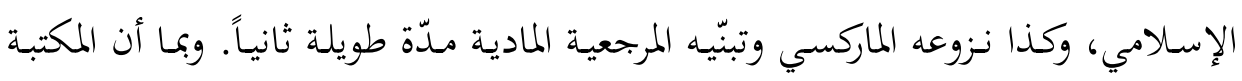

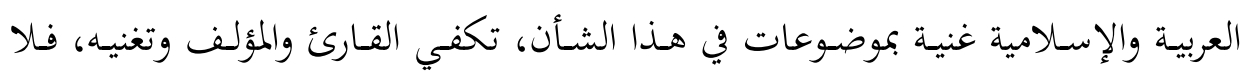

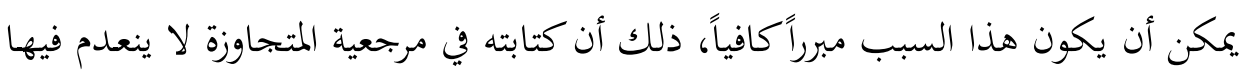

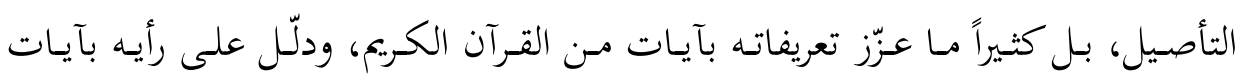

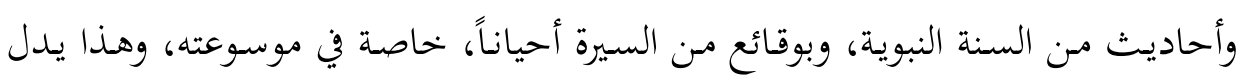

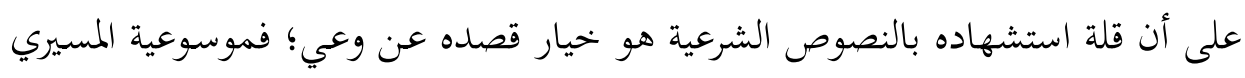

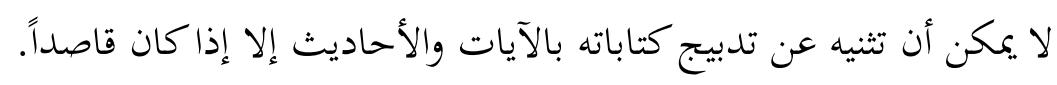
إن حديث عبد الوهاب المسيري عن المرجعية المتجاوزة، لا يمكن أن ينظر إليه بمنأى

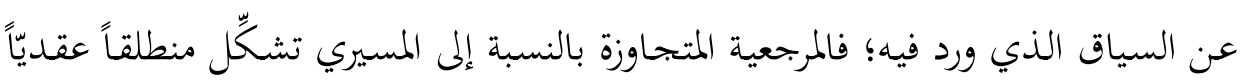

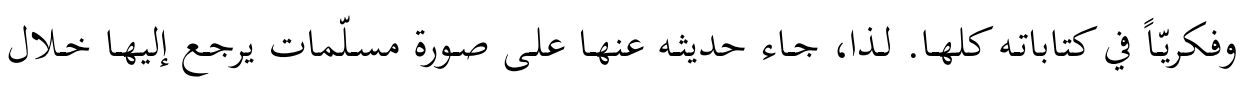

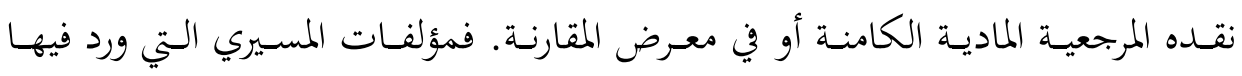

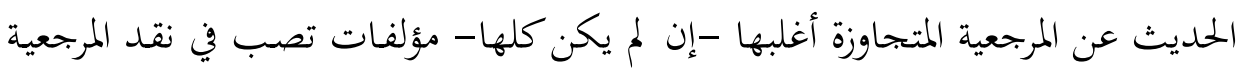

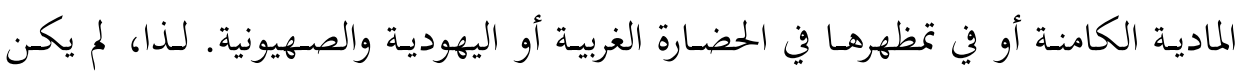


الحلديث عن المرجعية المتجاوزة مستقلًّ أبداً، وهنا يتبادر إلى أذهانـا سؤال آخر هو : إذا

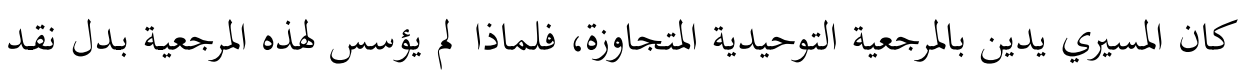

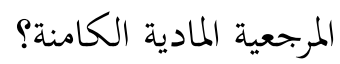

يُعبِّ الإبجاز المعريي والمنهجي الذي أبدعه المسيري -الذي جاء إثر تحول كبير من

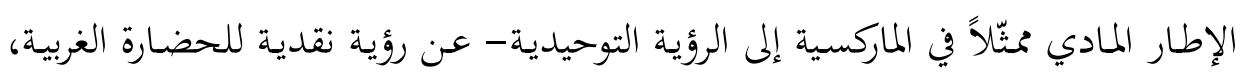

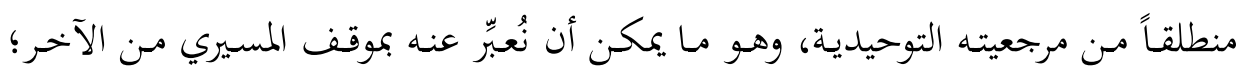

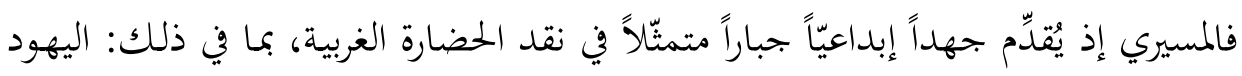

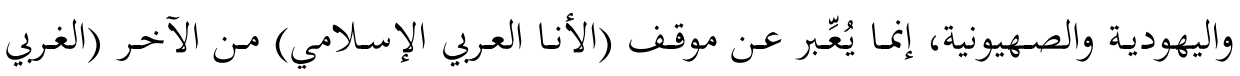

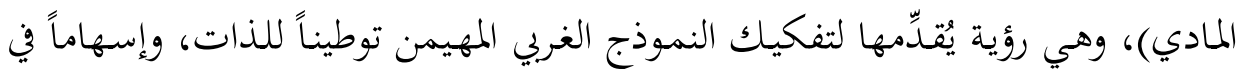

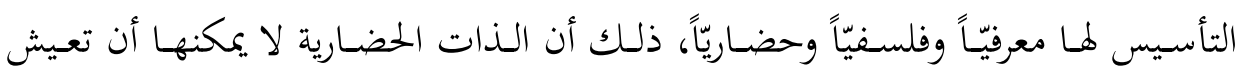

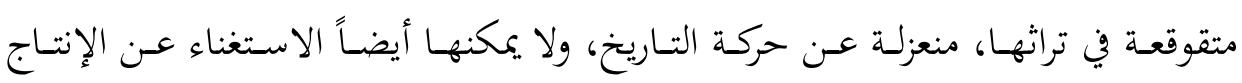

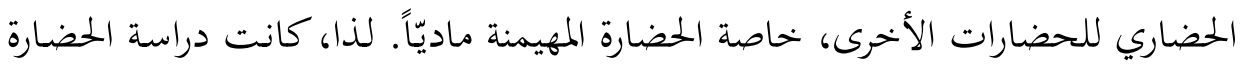
الغربية ونقدها خطوة استراتيجية لتحصين الفكر العربي الإسلامي من الوقوع في تحيزات النموذج المعري الغربي في ما يقدمه من منتوج حضاري؛ سواء أكان ماديّاً أم فكريّاً، وهو ما عبَّ عنه في مشروع فقه التحيز.

ولا يعد المسيري في دراسته التجارب الحضارية الأخرى بدعاً من المفكرين، فقد كان لمالك بن نبي وغيره من المفكرين أصحاب المشاريع الحضارية جولات في ذلك قبله، وإن

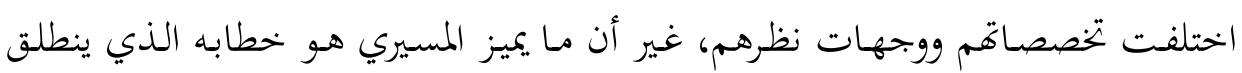

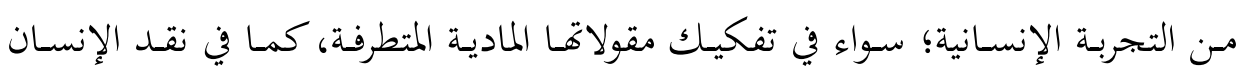

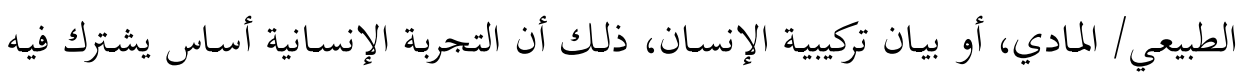

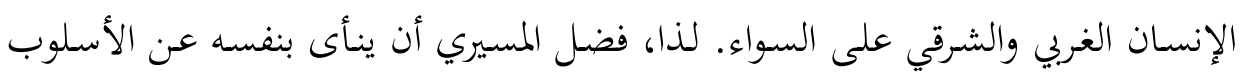
المباشر الذي ينطلق من النص الديني؛ احتراماً لتخصصه، واستفادة من بتربته، وليكون

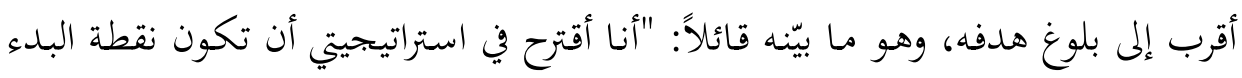

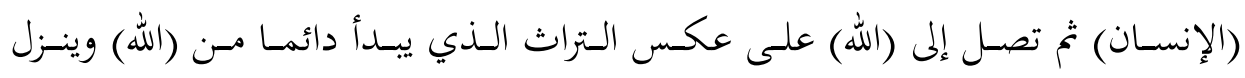


للإنسان، وهذا كان مفهوما من الناحية التراثية؛ لأن التراث كان يعيش في حضارة ليس بها كومبيوتر أو فيديو أو إذاعات... كان هناك اتفاق على قيم حضارية معينة، وهناك

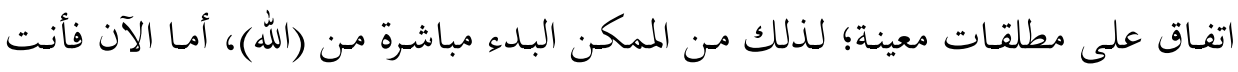
تخاطب جمهوراً يشرب الكوكاكولا ويأكل الهامبورجر ويشـاهد الفيديو ويتعرض للمادية

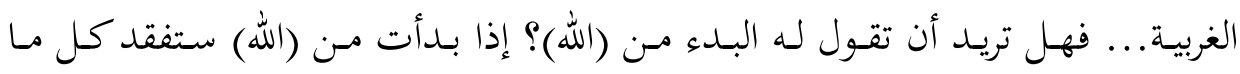

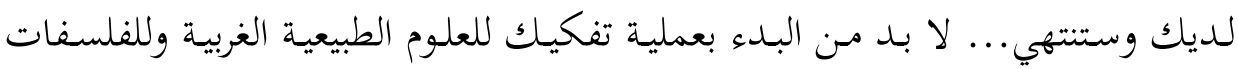

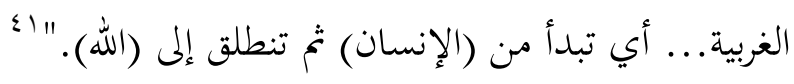

ثالثاً: فاعلية الإنسان والمشروع البديل ا ـ الإنسانية المشتركة وفاعلية الإنسان:

يستمد الإنسـان في المرجعية المتجاوزة فاعليته من الثنائيات الفضفاضة، فهو يتمايز

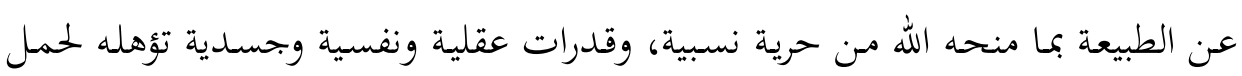

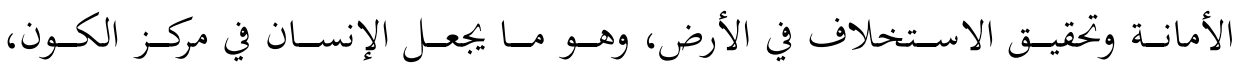

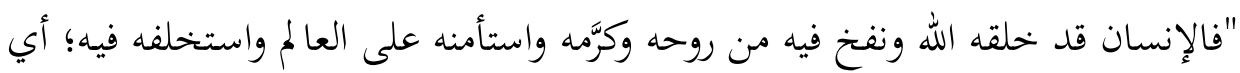

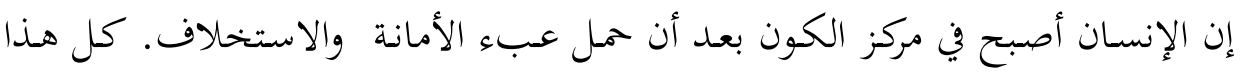
يعني أن الإنسان يحوي داخله بشكل مطلق الرغبة في التجاوز ورفض الذوبان فيان في الطبيعة،

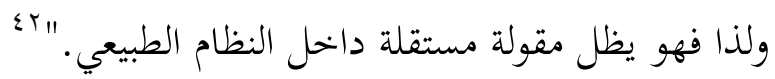

يحدد المسيري علاقة الإنسان بالله في تحليله المسافة التي تفصل بين الله الخالق،

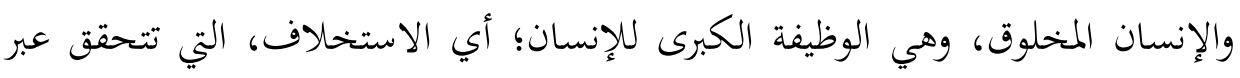
الزمن الذي هو بحال حياة الإنسان وفرصته في التحقق بالتوحيد وعبادة الله. وتحقيق

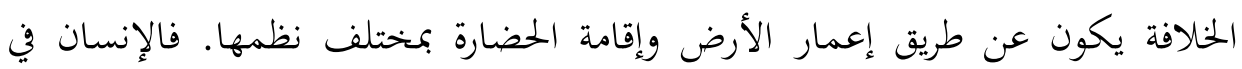

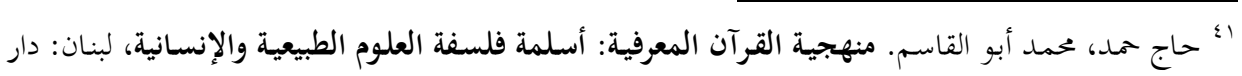

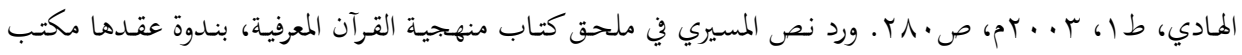

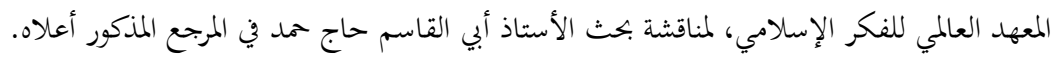

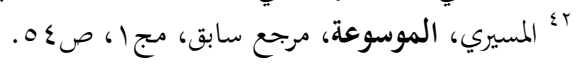


المرجعية التوحيدية المتجاوزة مكلف بذلك، غير أن تركيبية الإنسان من ثنائية المادة والروح

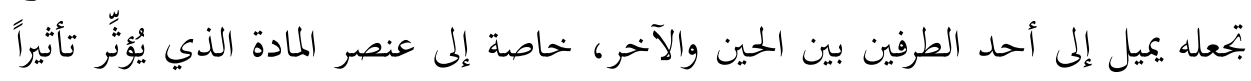

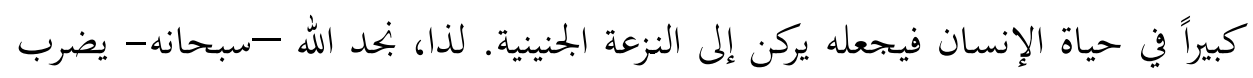

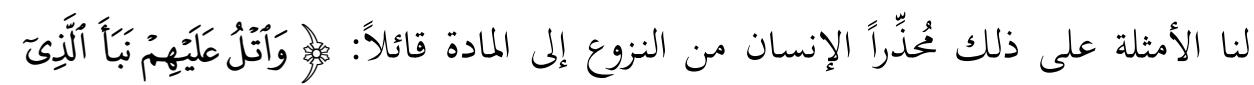

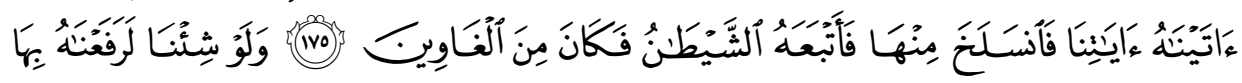

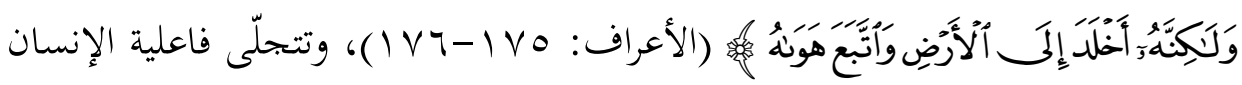
في الزمن في تراوحه بين طريف هذه الثنائية، ذلك أن "زمن الإنسان هو زمن العقل والإبداع والتغيير والمأساة والملهاة والسقوط، وهو المحال الذي يرتكب فئ فيه الإنسان الخطيئة

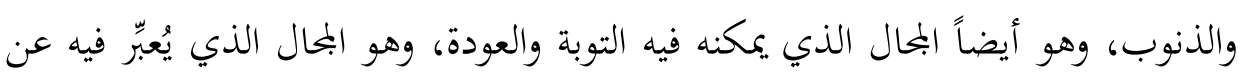

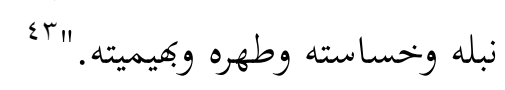

لذا، يحاول المسـيري استعادة الفاعل الإنساني وتركيبيته مـ خحلال مفهوم الإنسانية

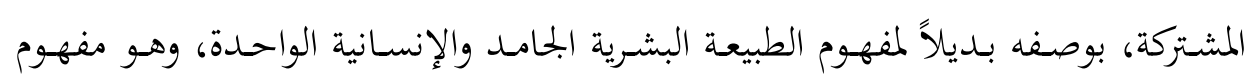

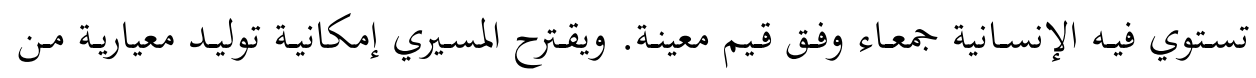

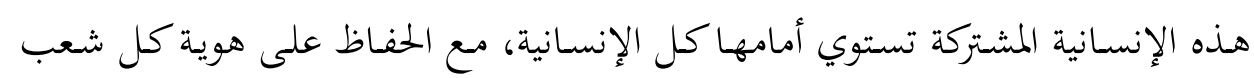

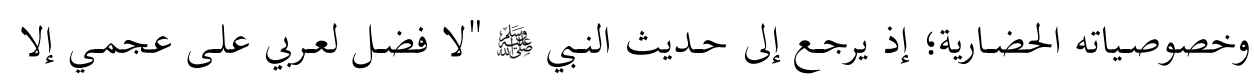

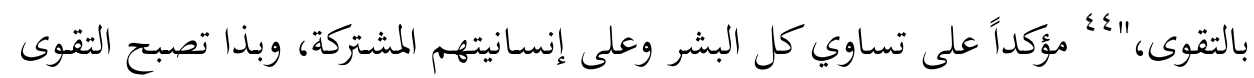

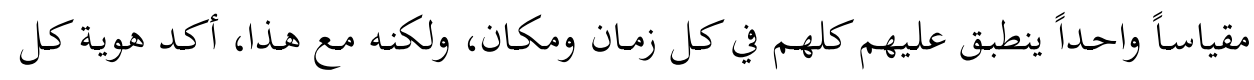

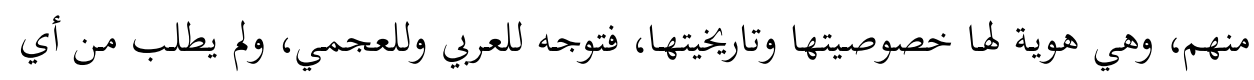

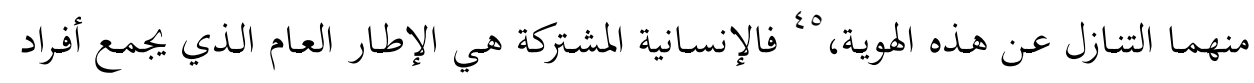

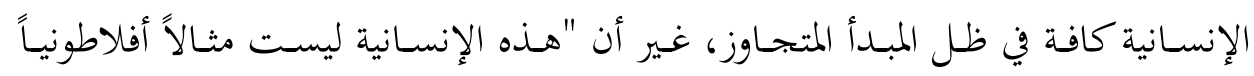
جامداً يتجاوز الواقع تماماً، بحيث يصبح الواقع بحرد ظلال له، وإنما هي إمكانية (بشرية).

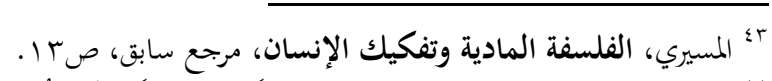

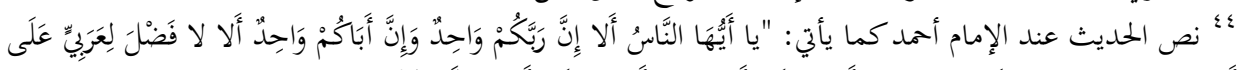

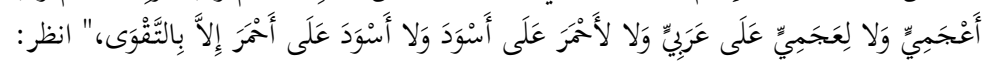

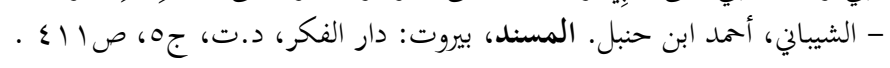

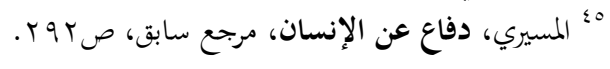




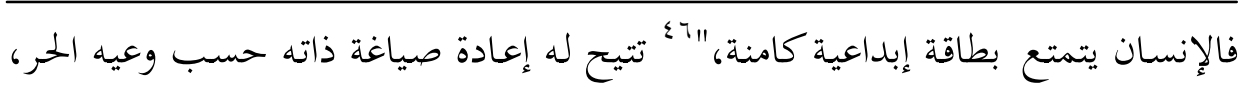
وما يتوصل إليه من معرفة، من خلال تراكم بتحاربه، فضلاً عن تطويره منظومات أنسات أخلاقية وجمالية وغيرها من الأشكال الحضارية.

وبالرغم مـن أن المسيري لمُ يُحسِّد معـالم الإنسانية المشتركة، وحسدود علاقة الإنسـان

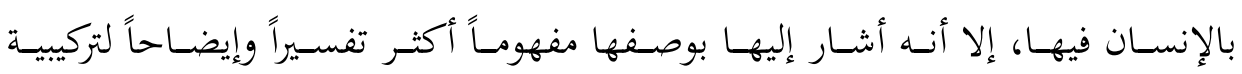

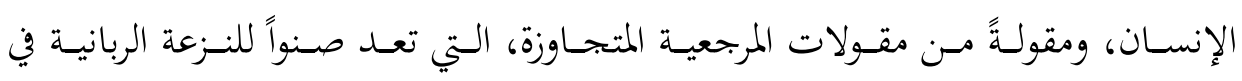
الإنسان، ويمكن من خلالما تحديد الرؤية الكلية والنهائية للإنسان، "فالإنسانية المشتركة، تلك الإمكانية الكامنة فينا، هذا العنصر الرباني الذي فطره الله فينا (ودعمه بما أرسله لنا

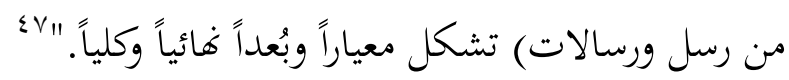

مـن هنــا يـرى المســيري ضـرورة اسـتخدام النمـاذج المركبـة لدراسـة الإنسـان؛ إذ إن إن إنـان النماذج الاختزالية لا تكفي لتفسير الظاهرة الإنسانية، ذلك أن النماذج التحليلية المركبة تتميز بمقدرة تفسيرية للظاهرة الإنسانية دون السقوط في السيولة والعمومية والعنصرية. تخ تأتي ثنائية الإنسان والطبيعة التي تأخحذ شكل تفاعل إيجابي لعمارة الأرض وتحقيق

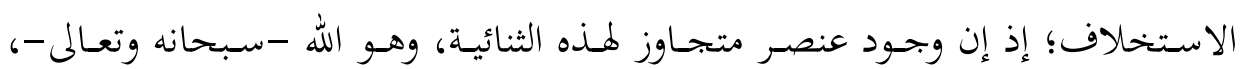

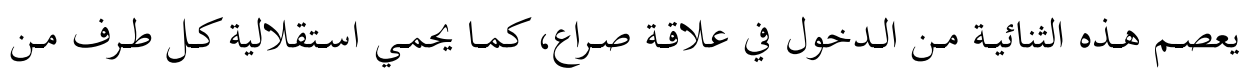

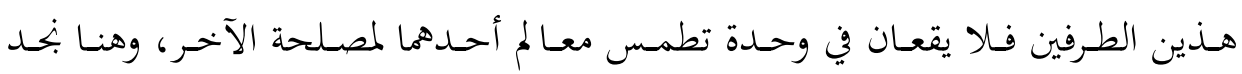

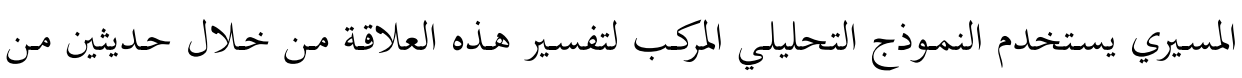

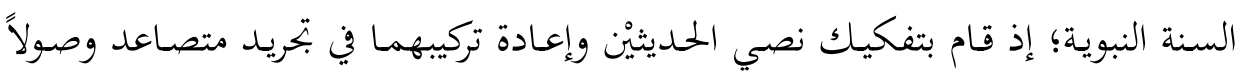

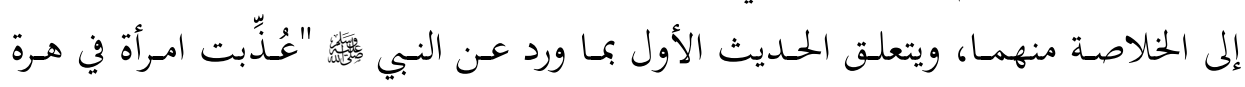

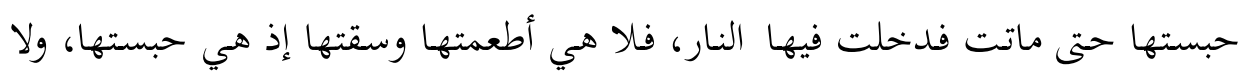

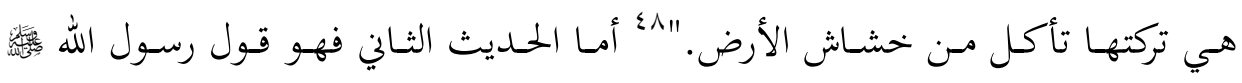

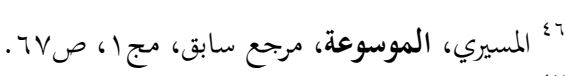

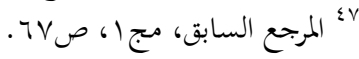

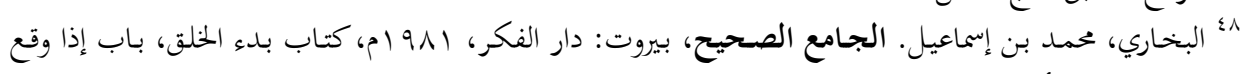

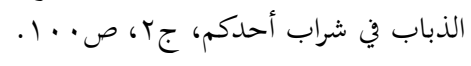


"بينما رجل يمشي، فاشتد عليه العطش فنزل بئراً فشرب منها ثم خرج، فإذا هو بكلب البه

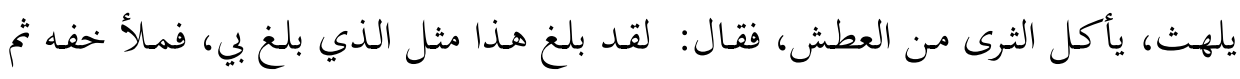

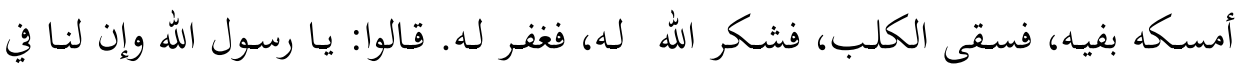

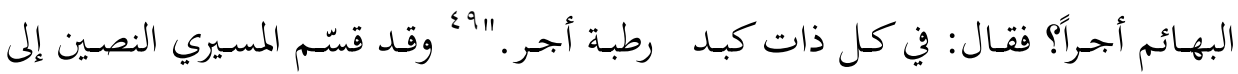
وحدات منفصلة تُشكّل البنية اللفظية للحديثْنْ على النحو الآتي: ؛

$$
\begin{aligned}
& \text { أ. في الحديث الأول: امرأة-هرة-جوع-زيادة الجوع-موت-جهنم. } \\
& \text { في الحديث الثاني: رجل-كلب-عطش-سُقيا-حياة-جنة. }
\end{aligned}
$$

يبدو من الوهلة الأولى وجود التقابل بين الحمديثين: رجل/ امرأة، هرة/ كلب، جوع/

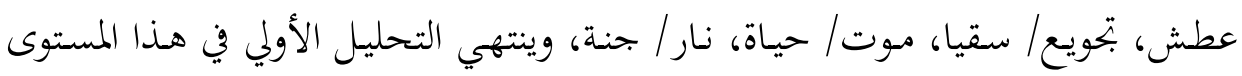
إلى المضمون السطحي.

ب. ثم يزيد المسيري في مستوى التجريد قليلاً بحيـث تتجـاوز وححدات كل حسديث الفضاء الزماني والمكاني المباشر لكل منهما، حتى يمكن رؤيتهما في علاقة كل منهما

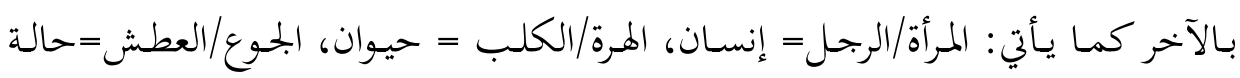

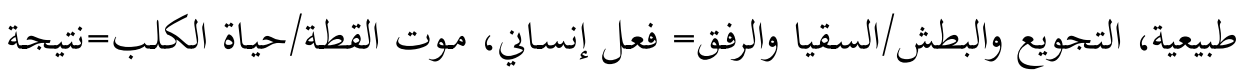

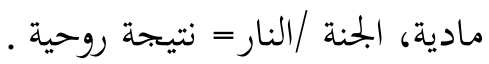

ت. ثم يزداد التجريد على النحو الآتي: فاعل/إنسان، مفعول به/حيوان، فعل يؤدي

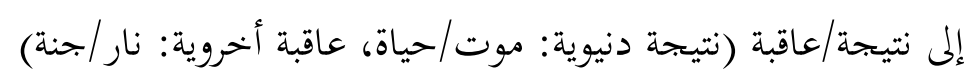
ث. ثم يرتفع المسيري بالعملية التجريدية إلى المستوى المعرفي ورؤية الكون، باستخدام

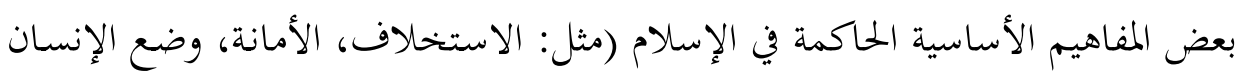

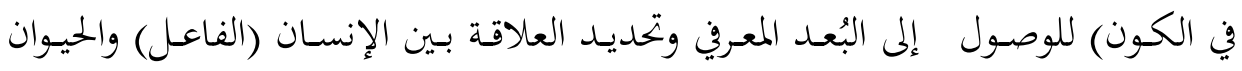

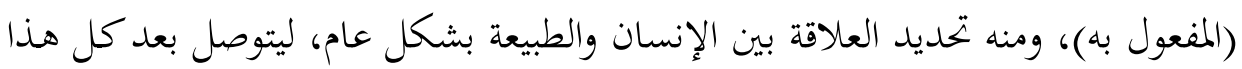

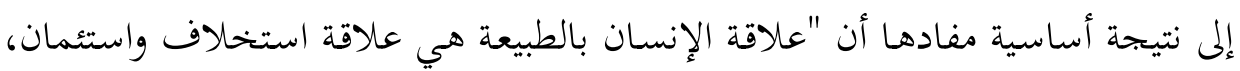

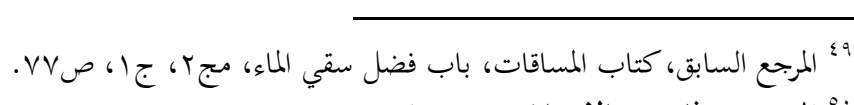

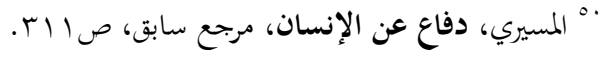


فالإنسان يُوجَد في مركز الكون لأن الله كرمه وحباه عقلاً وحكمة. وقد أعطاه الله الطبيعة

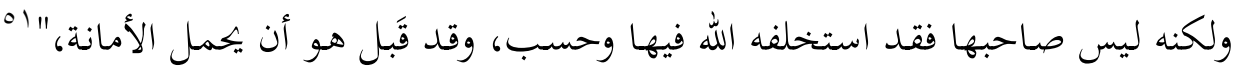
وهو ما يشير إلى التوازن بين الإنسان والطبيعة المبني على تميز الإنسان وتفرده ومسؤوليته. فالعلاقة بين الإنسان والطبيعة علاقة تسخير بموجب الأمانة التي حمّلها الإنسان،

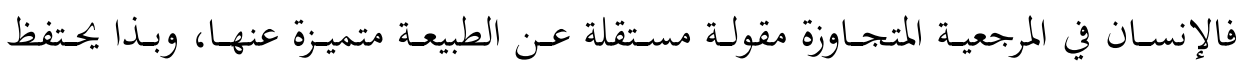

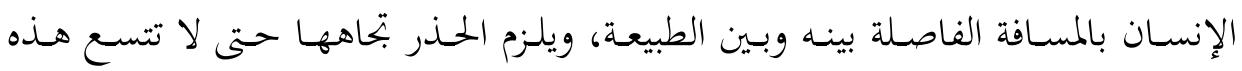
المسافة ويتأله الإنسان في الطبيعة، أو تصبح العلاقة بينه وبين الطبيعة علاقة صراع، يهاول

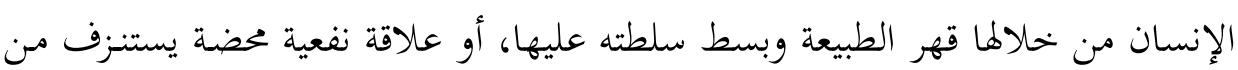

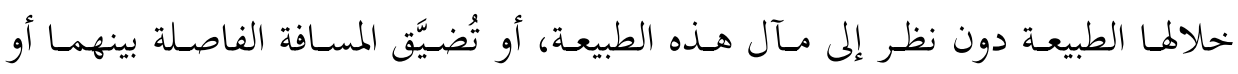

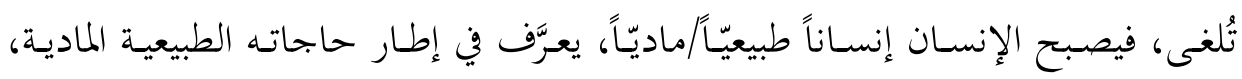
ويطمس هويته ويعطل وظيفته الوجودية، وقد وصف لنا المولى -عز وجل - هذا الإنسان

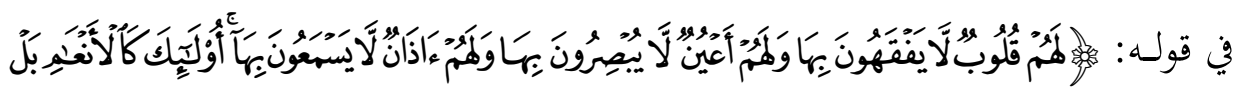

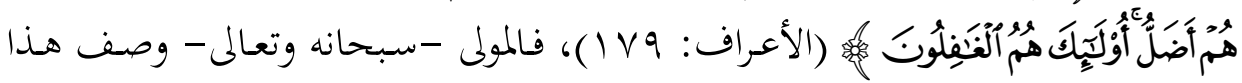

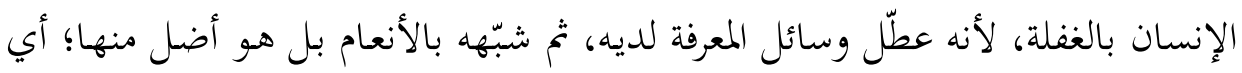
إن الإنسان في هذه الحالة ألغى المسافة التي بينه وبين الطبيعة فتساوى معها، تمح نبّهنا الله

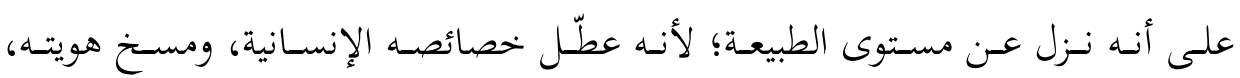

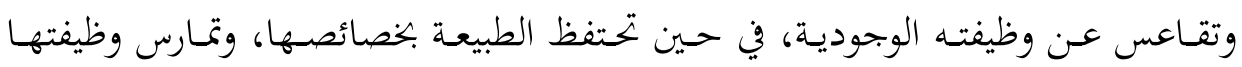
الوجودية التي خلقها الله من أجلها.

وعلى الرغم مـن أن المسيري لم يُفصِّل في العلاقات الناجمة عن الثنائيات الفضفاضة

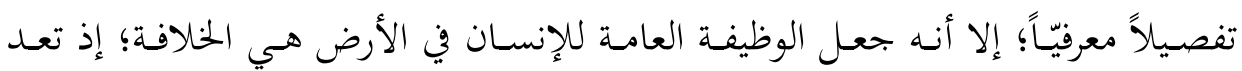

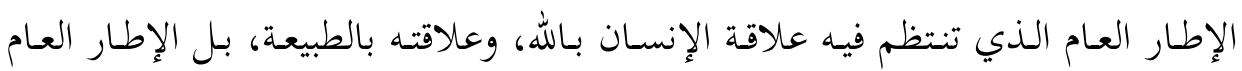

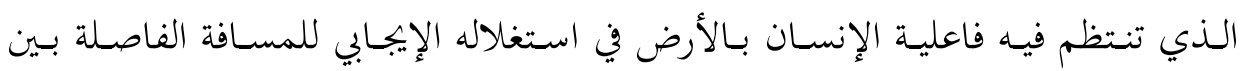
الثنائيات الفضفاضة. 
وإذا نظرنـا إلى توظيف المسـيري لمصطلح الاستخحلاف ومركزيـة الإنسـان في الكـون، وما يكيط بهما من مصطلحات أخرى، تبين لنا أن الإنسان لا يجتل مركز الكون أصالة وإنما باستخلاف من الله تعالى؛ بغرض تعمير الأرض والعبادة وتحقيق الخلافة. للذا، بند

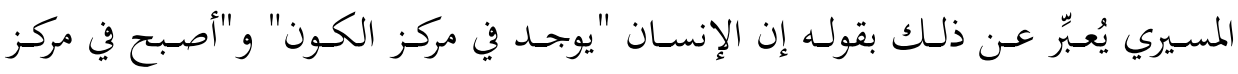

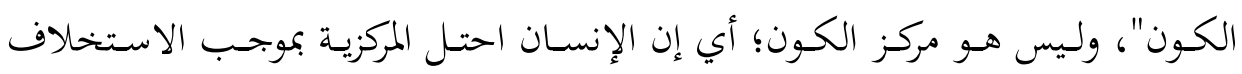

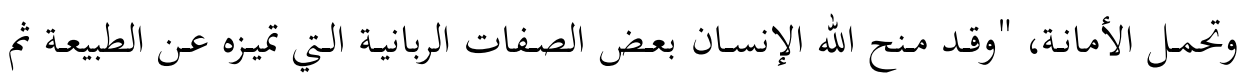

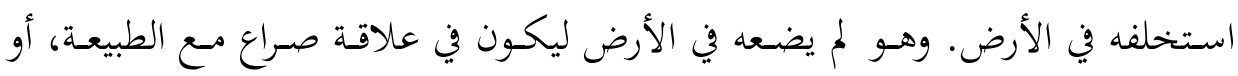
ليوظفها، وإنما استخلفه فيها واستأمنه عليها ليستخدمها ويعمرها، وهو يكتسب مركزيته

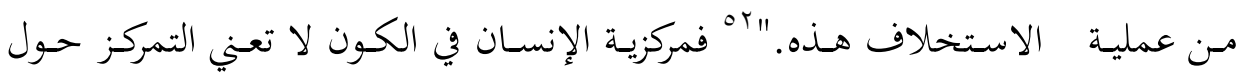
الذات؛ إذ يصبح الإنسان هو مركز الكون ومرجعية ذاته والكون، وإنما المركزية المطلقة لله

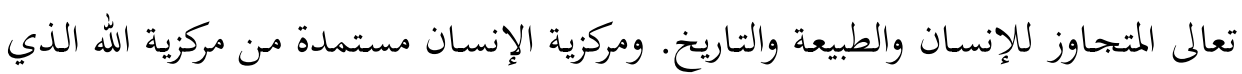

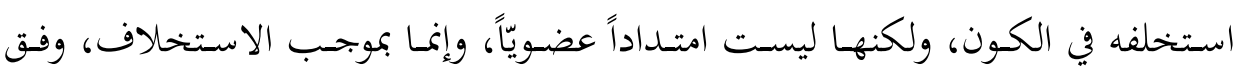
المسافة الفاصلة بينه وبين الله، وهي مسافة مقدّرة بقدرها، لا يجبوز إلغاؤها ولا تضييقها ولا توسيعها، فهي الحيز الذي يتحرك فيه الإنسان بحرية ومسؤولية، فإما أن يحقق الإنسان

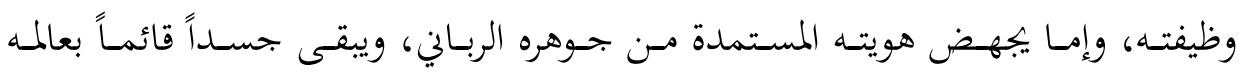
الحيواني، فهو كالحيوان أو أضل سبيلاً.

ومركزية الإنسـان لا تعني سيادته على الطبيعة لبسط سلطته عليها، بل يقصد بهـا

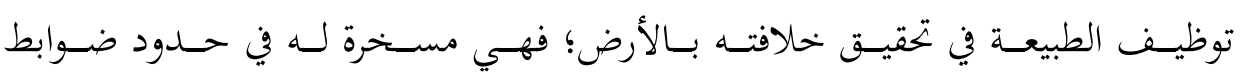
الاستخلاف،" وكل شيء في الطبيعة له مكانته ووظيفته وقيمته في ذاته، فالعا لمكل متكامل (ومن المنظور التوحيدي، كل شيء في الكون قد ناله نصيب من التكريع لأنه من خلق الله وبديع صنعه)، وهذا يعني أن الإنسان ليس موجوداً في الكون بمفرده، فالكائنات

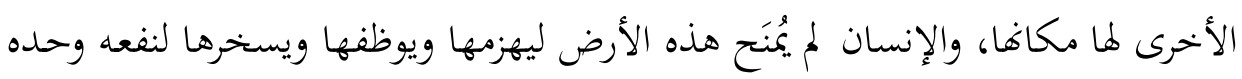


دون حدود، فلا بدّ له من الحفاظ عليها؛ لأنه -حسب الرؤية التوحيدية- قد استخلفه

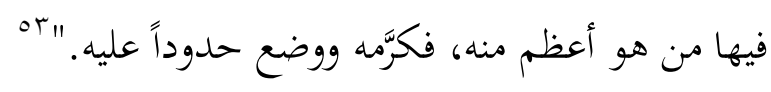

كما يحيط المسيري مفهوم الاستخلاف بمصطلحات: التكريم، والأمانة، والتعمير؛ إذ بحده يقرن مفهوم الاستخلاف ومركزية الإنسان بهذه العناصر الثلاثة ويجعلها شرطاً له؛

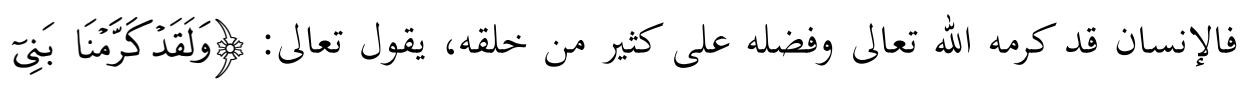

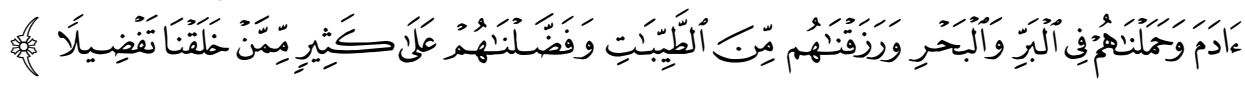

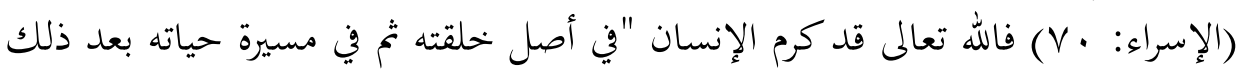

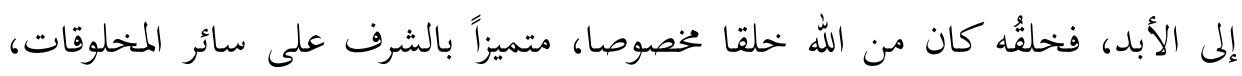

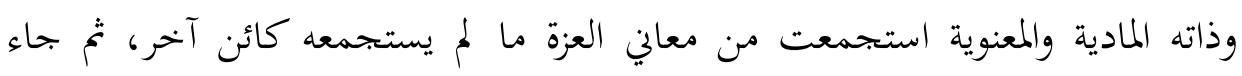

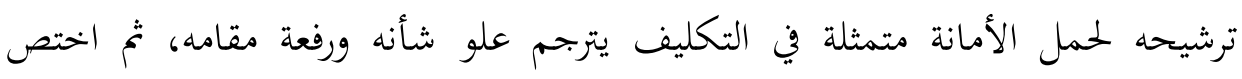

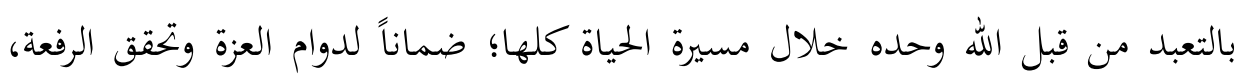
وتوج كل ذلك بالخلود في الحياة الأخرى، حيث جعل الله الموت مرحلة انتقال من حياة

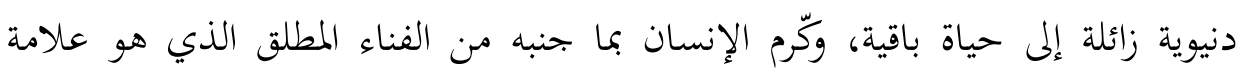

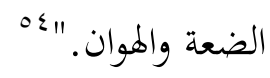

وتحقيـق الاسـتخلاف في الأرض موقوف على حفــاظ الإنسـان على هـذا التكـريم

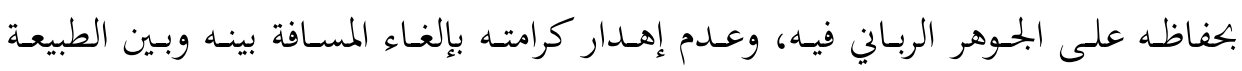

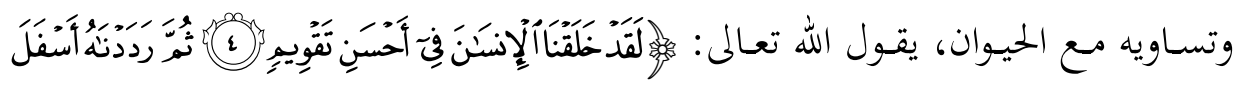

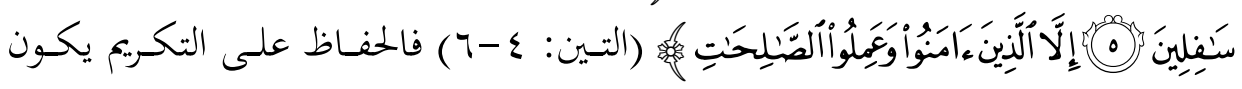

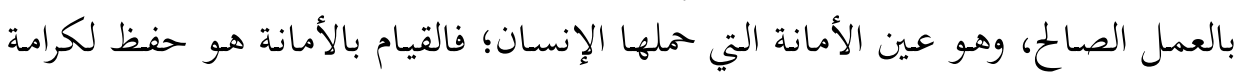

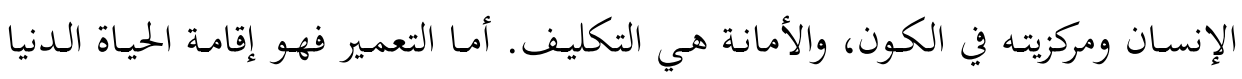

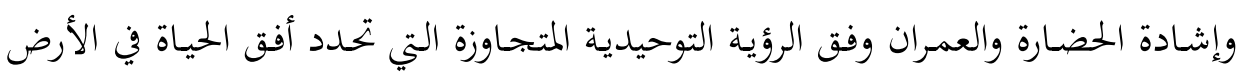

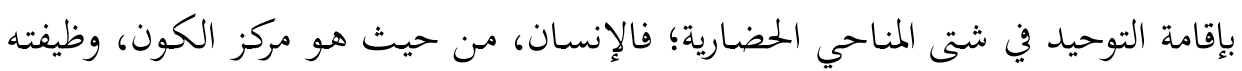

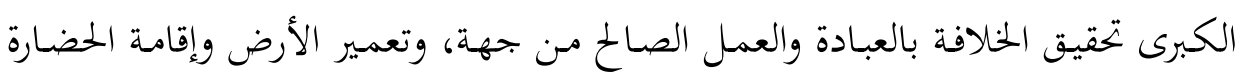




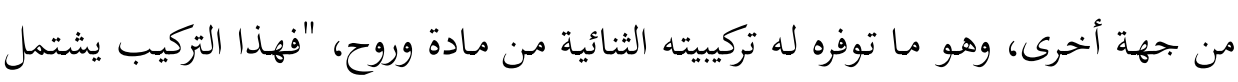

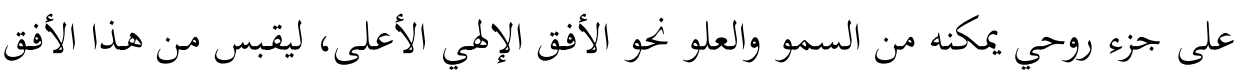

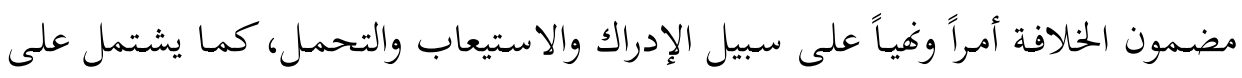

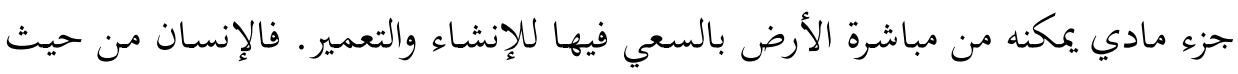

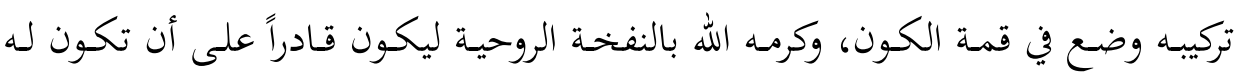

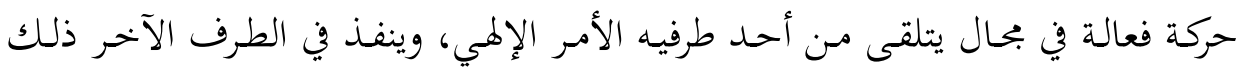

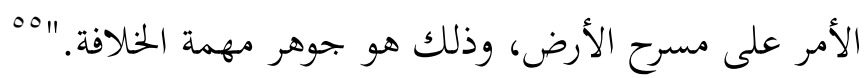

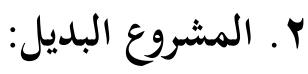

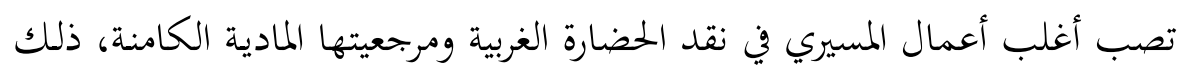

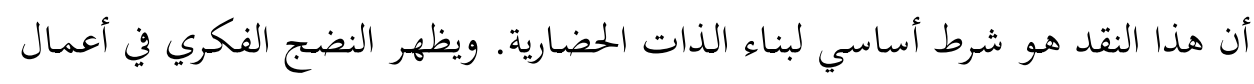

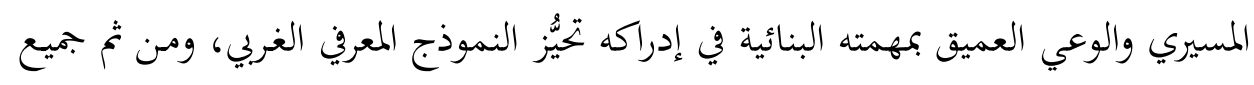

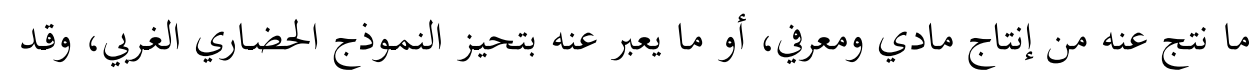

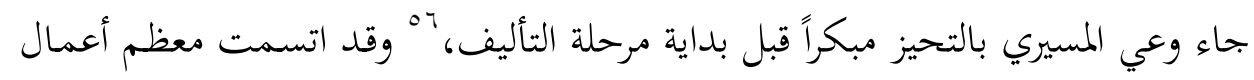

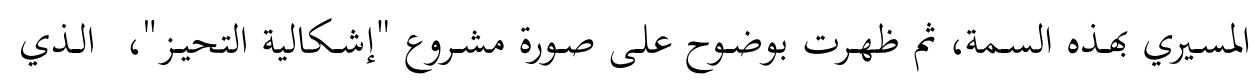
ظهرت سمة الاجتهاد فيه من خلال عنوانه الفرعي "رؤية معرفية ودعوة للاجتهاد".

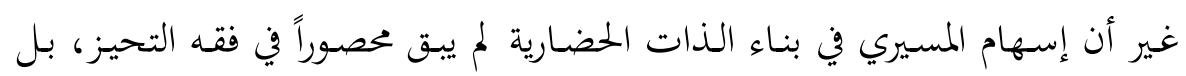

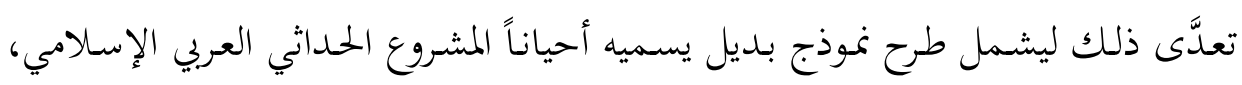

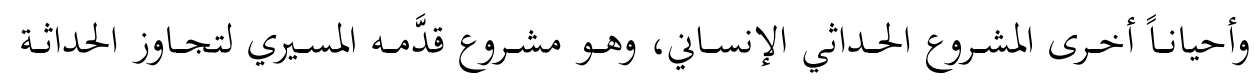

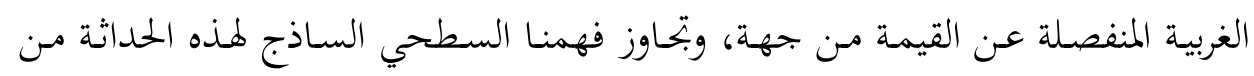

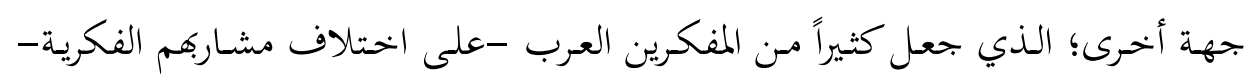

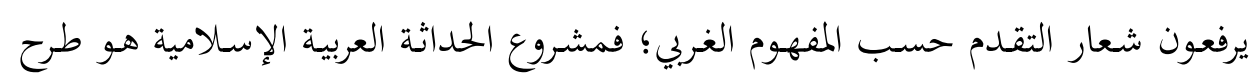

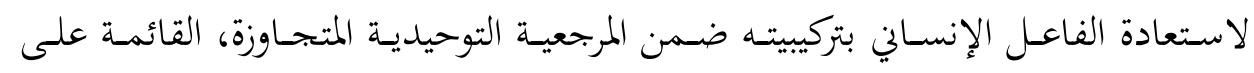

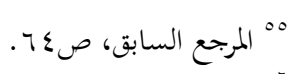
"ه المسيري، عبد الوهاب، رحلتي الفكرية في البذور والجذور والثمر؛ سيرة غير ذاتية غير موضوعية، مصر: دار

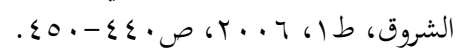




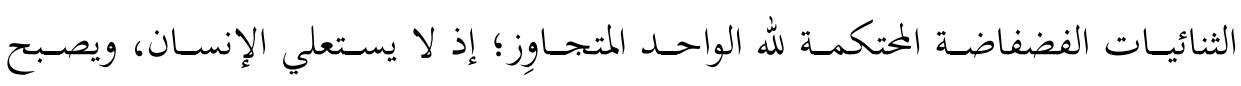

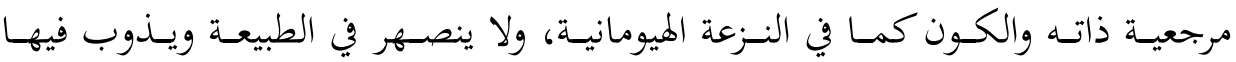
وتتحكم فيه الواحدية المادية المفضية إلى العدمية. لذا، يضع المسيري جملة مـن الشروط

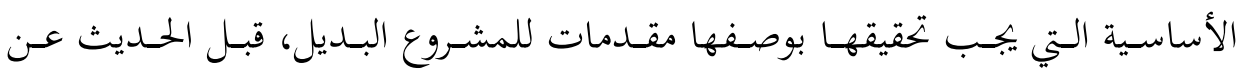
المنطلقات الأساسية لمذا المشروع.

\section{أ. الشروط الأساسية للمشروع البديل:}

على الرغم من أن المسيري قد عدّ الذات منطلقاً أساسيّاً في مشروعه البديل؛ إلا أنه يبني رؤيته على معرفة الآخر الغربي الذي يعد نموذجاً حضاريّاً مهيمناً. وانطلاقاً من ذلك، الكياً

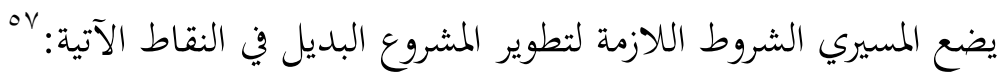

* إدراك المناحي الإيجابية في نموذج الحداثة الغربي: فإدراك أزمة الحداثة الغربية لا يبرر رفضها رفضاً قاطعاً؛ إذ الرفض القاطع والقبول الكامل يشتركان في اتخاذ الغرب مرجعية صـامتة، لـذلك يـرى المسـيري أنه مـن الضـروري الوقوف على إيجابيـات الحداثـة الغربيـة والاستفادة منها وفق رؤيتنا المرجعية، من مثل:

- التطور الملحوظ في فن الإدارة أو مـا يسميه المسيري الإدارة الرشيدة للمؤسسات

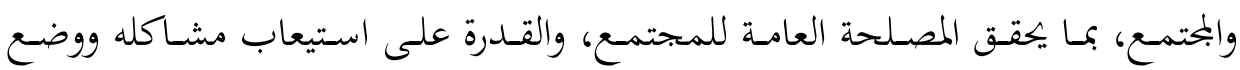
حلول لها بشكل مستمر من خلال الإجراءات الديمقراطية، والفصل بين السلطات. - القـــرة على بتحديـد الخلافـة في قيـادة الدولـة والبمتمـع على المسـتويين: مسـتوى الرئاسة؛ أي مَن يخلف الرئيس، ومستوى النخب السياسية والاقتصادية والثقافية، وهـو

- تأكيد الحرية الفردية، واحترام حقوق الإنسان السياسية. 
- ترسيخ فكرة الولاء للوطن بوصفها مقوماً رئيساً مس مقومـات الدولة، وتنميـة

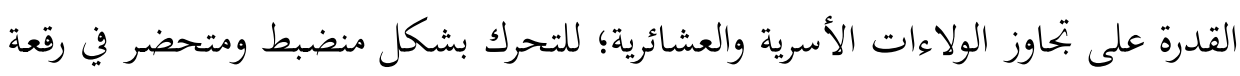
الحياة العامة.

- تطوير الخـدمات الاجتماعيـة التي تسـتجيب لمتطلبـات الإنسـان، أو مـا يسميه المسيري إنشاء دولة الرفاه.

$$
\text { - تفعيل دور المرأة وتأكيد حيزها المستقل. }
$$

- فسح المحال للقدرات الإبداعية وتطويرها، وكذا أسس النقد البناء. - تطـوير منـاهج البحــث علـى نحـو مسـتمر يسـتجيب لسـرعة تطـور البحتمــع واحتياجاته.

- اتحاد دول عدّة على اختلاف انتماءاتها، عن طريق إنشاء مؤسسات كبرى تضم مختلف الشركات على أسس مشتركة.

وغير ذلك مـن الإيجابيات التي لا يمكن التغاضي عنها، بـل يمكن الاستفادة منها

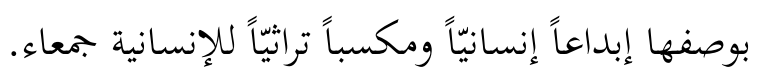

* إدراك أثر الإمبرياليـة: إن إدراك إيجابيـات الحداثنة الغربيـة لا يَجــُُّ إمبرياليتها التي

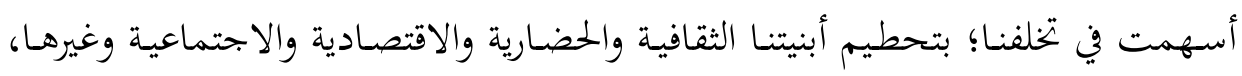

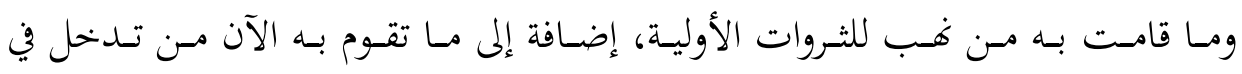

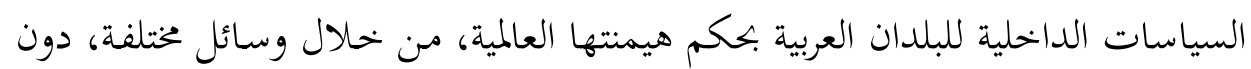
أن يقف بنا إدراكنا لإمبريالية الحداثة الغربية على عتبة الاستضعاف والاغززام الذاتي. * رفض تمجيد الذات: إن رفض الحداثة الغربية المنفصلة عن القيمة لا ينطلق من

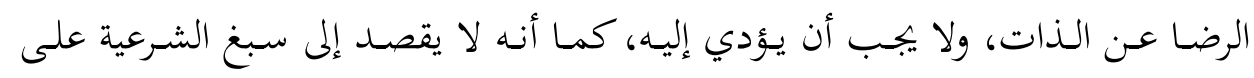

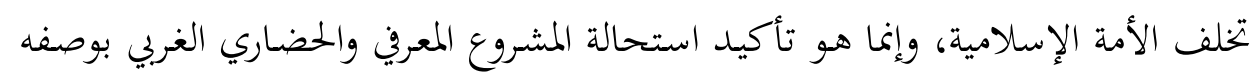

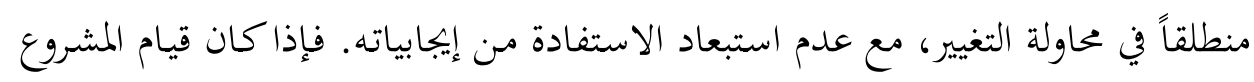

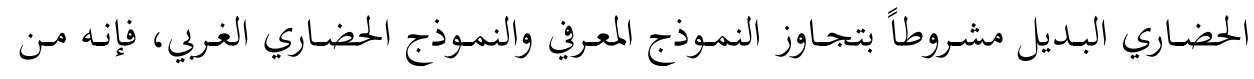


الناحية المنهجية والمعرفية لا يمكن قيام مشروع بديل بمنطق المركزية العربية الإسلامية القائم

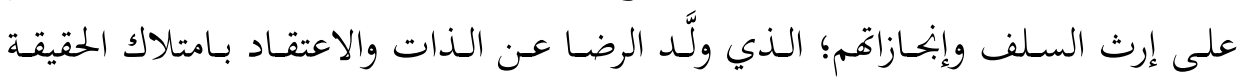

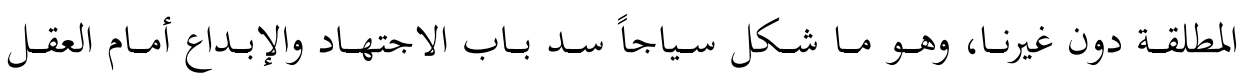
الإسالمي.

* إدراك الضعف الداخلي: إذ لا يمكن قيام المشروع البديل دون رصد لتخلف الأمة

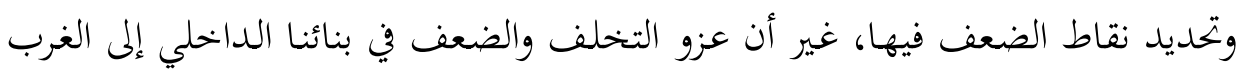

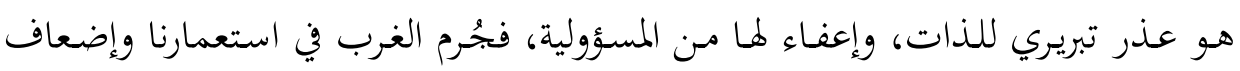

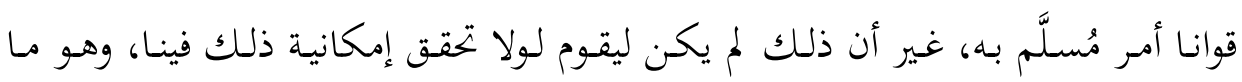

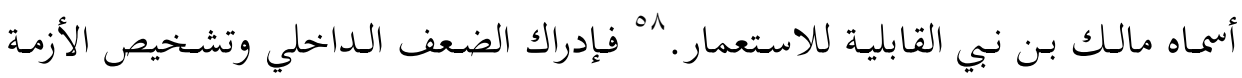
شرط رئيس لقيام المشروع البديل، وهنا بحد المسيري -إضافة إلى اقتباس مفهوم القابلية

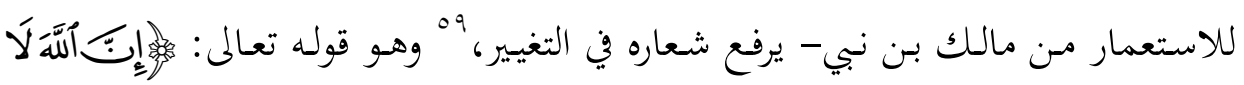

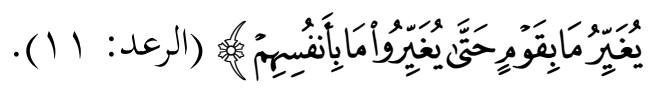

\section{ب. المنطلقات الأساسية للمشروع البديل:}

في ما يأتي أبرز المعايير التي عَدّها المسيري أساسية ولازمة لتطوير المشروع البديل: ا ـ يقـين ليس بكامـل واجتهـاد مسـتمر: ‘ ب بمـا أن الواقـع الإنسـاني يتميـز بالتعـدد

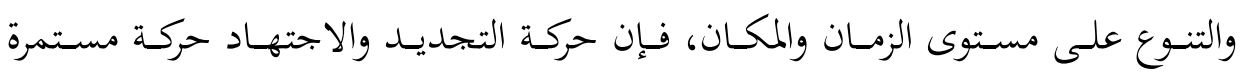
متواصلة؛ تبني على الجهود الإنسانية السابقة، ولا تتوقف عندها (سواء أكانت إسلامية

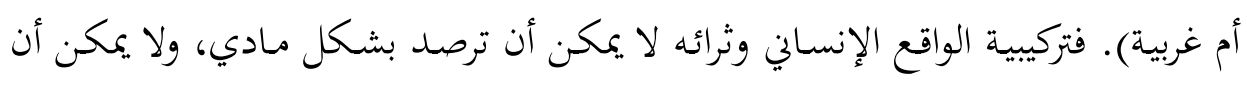

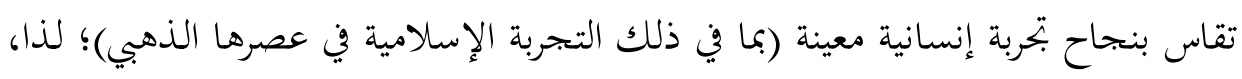

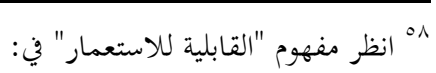

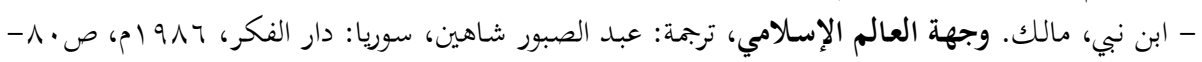

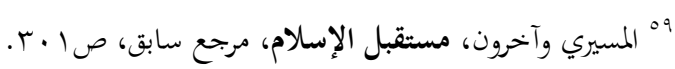

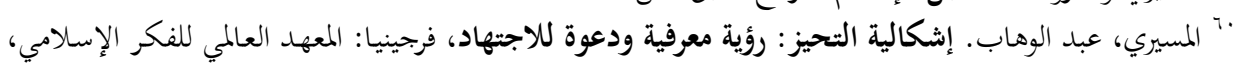

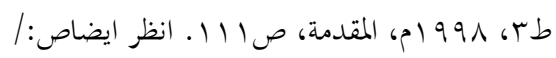

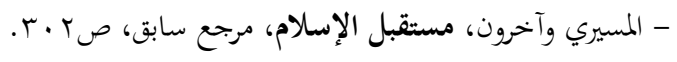


فتفسير هذا الواقع الإنساين يحتاج إلى نماذج تفسيرية اجتهادية على المستويين الإنساني

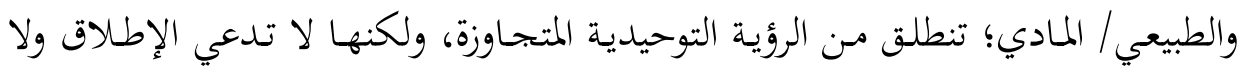
الإحاطة بهذا الواقع. r. لا يوجد بحال للتحكم الكامل في الواقع: آ إن الله تعالى خلق الإنسان وكرَّهـ،

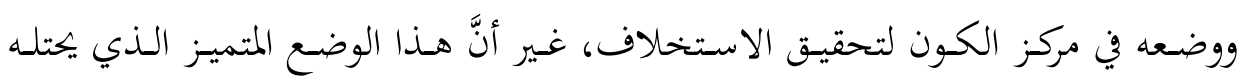

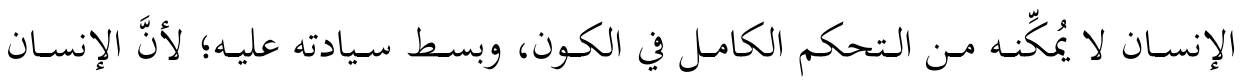

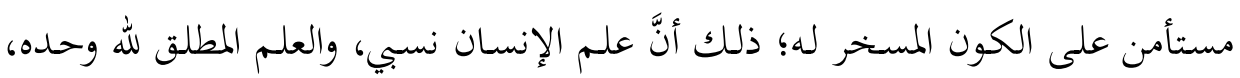

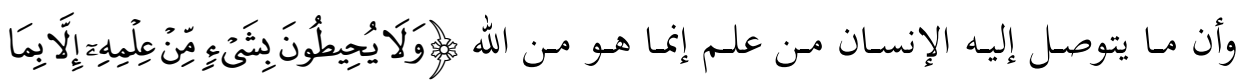

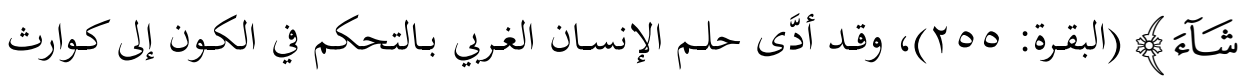
بيئية جراء التجارب الكيميائية، وإمبريالية شرسة خربت الأرض وأبادت الإنسان، وازداد سعار الإمبريالية بالتنافس على التسلح وتطوير أسلحة الدمار الشامل وأنواع متعددة من لـإِ

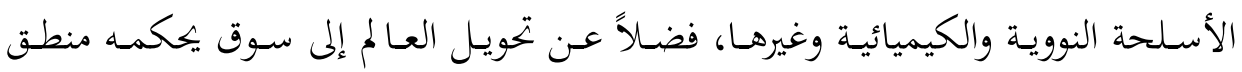
العرض والطلب لــــا فبإن النمـوذج البـديل ينطلق مـن المرجعيـة التوحيديـة في تعامله مـع الكون، وفق الضوابط والمصالح الشرعية التي تحقق التوازن وإعمار الأرض. r. لا اختزال ولا تصفية للثنائيات:بَ ينطلق النموذج البديل مـن رؤية كلية وهائية للإنسـان والكـون والحيـاة قائمـة على الثنائيـات الفضفاضـة؛ إذ تتميـز أطراف الثنائيـات باستقلالية نابتحة عن المسافة الموجودة بينها وبين الأطراف المقابلة لما، فالعلاقة التي تسود هـذه الثنائيـات هي علاقـة تفاعلية تكاملية، يتـداخل فيها العـام في الخـاص، والكلي في الجزئي، والمطلق في النسبي، والدال في المدلول؛ إذ لا يمكن تصفية هذه الثنائيات لمصلحة

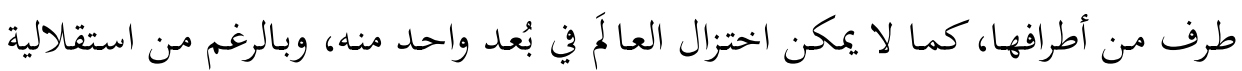

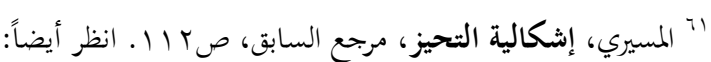

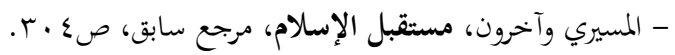

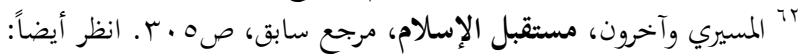

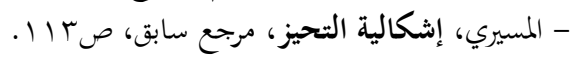




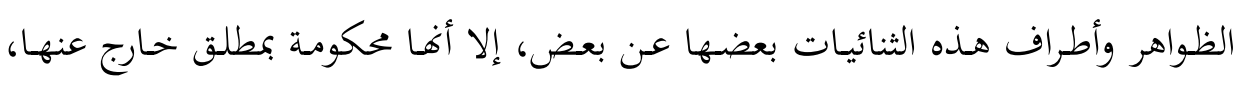
هو الله تعالى، وعلى ذلك يجب على المشروع البديل الابتعاد عن النماذج الاختزالية. ع. محاولة الوصول إلى نظرية شاملة: با يطمح المسيري في مشروعه البديل الوصول

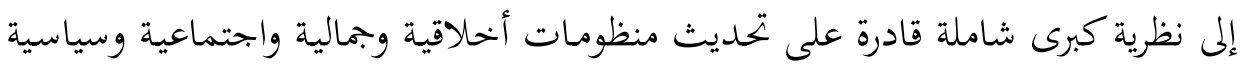

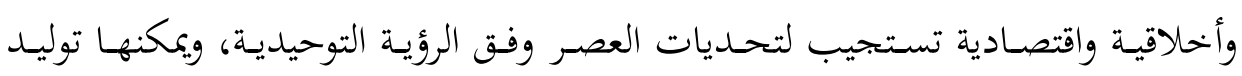

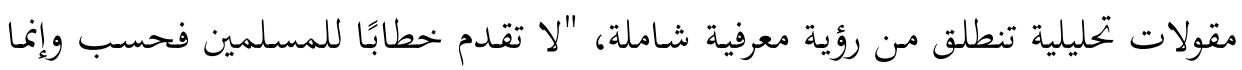

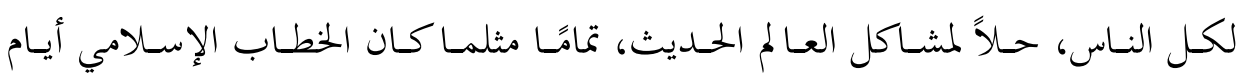

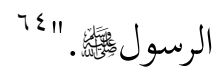

ه. نموذج توليدي استكشافي غير تراكمي:" ينطلق المشـروع البـديل مـ الإيمـان

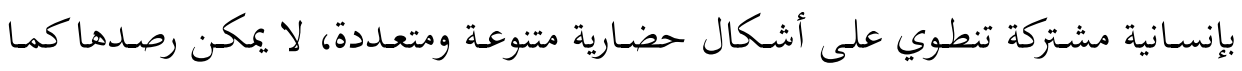

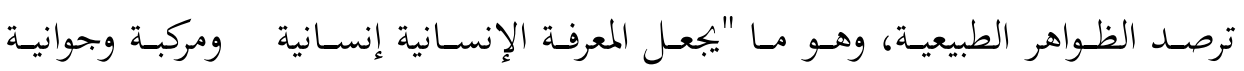

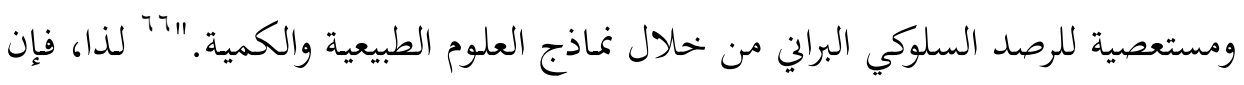

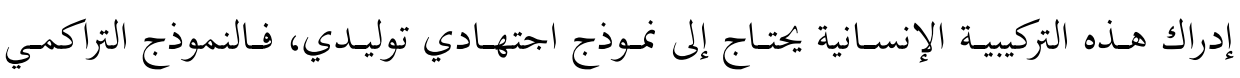

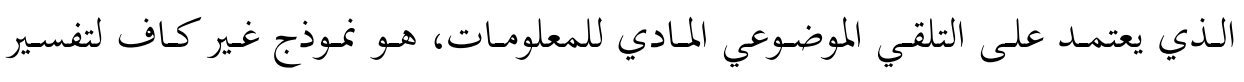

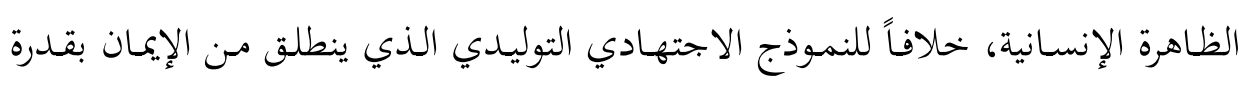
العقل على الإبداع؛ نظراً إلى ما يتميز به من فاعلية واستقلالية عن الطبيعة/ المادة.

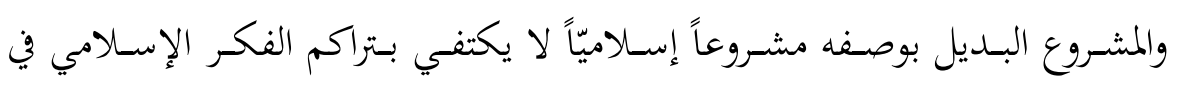

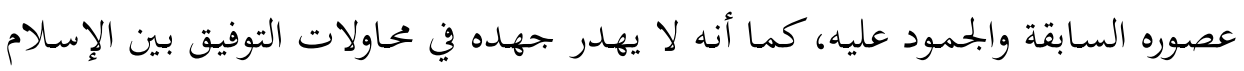

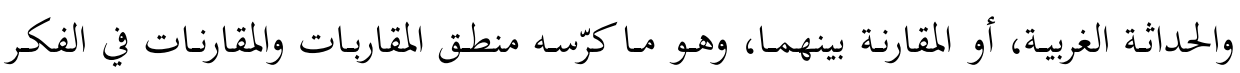

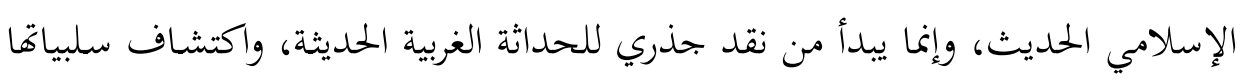

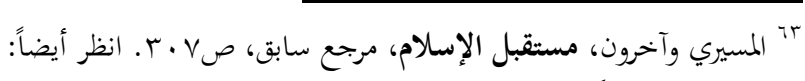

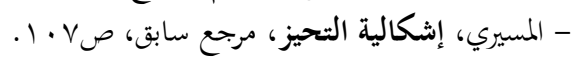
" \$" المرجع السابق.

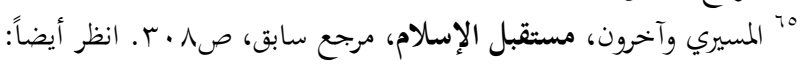

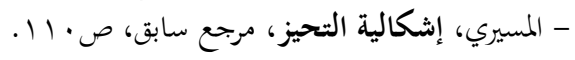

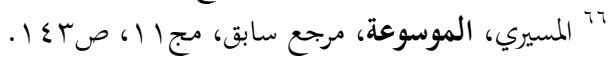


وإيجابياتها، مع الاحتفـاظ بمسـافة بينه وبينها، تم العودة إلى المرجعيـة التوحيدية المتجـاوزة

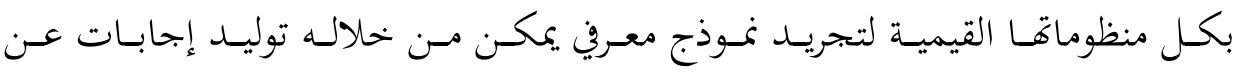
الإشكاليات التي أثنارتا الحداثة الغربية، والإشكاليات التي تنضح بها تحديات الواقع.

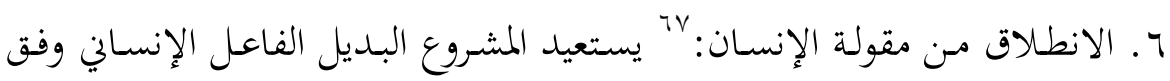
الرؤية التوحيدية، بوصفها عنصراً رئيساً ومحرَكاً، على أساس أن الإنسان هو مركز الكون

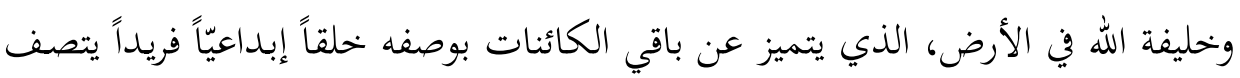
بقدرات عالية، أولها القدرة على بحاوز الطبيعة ورفض الذوبان فيها على نحو مطلق. إن

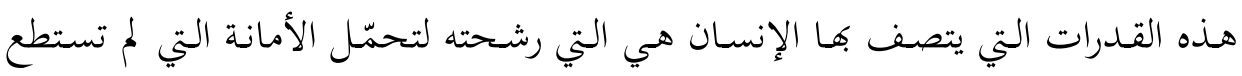
السموات والأرض والجبال (الطبيعة) حملها، وهو ما جعل الإنسان خليفة الله في الأرض. ويسوّغ المسيري انطلاق مشروعه البديل من الإنسان لفك هيمنة النموذج الحضاري الغربي على الإنسان المسلم، بالاعتماد على تشخيصه للواقع المعاصر الذي افتقد القيم

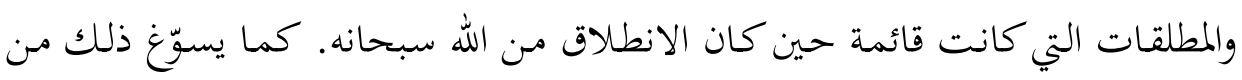
تشخيص الحاجة المعاصرة إلى تطوير خطاب معاصر يتوجه إلى الإنسـان، كل الإنسان،

وليس إلى الإنسان المسلم وحسب.

V. نابع من التراث: ^" يجعل المسيري التراث هو الأساس الذي يبنى عليه المشروع البديل، ويقصد بالتراث "بحمل التاريخ الحضاري الذي يتسع للإبنحازات المادية والمعنوية لإنية

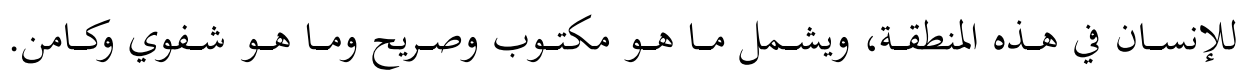

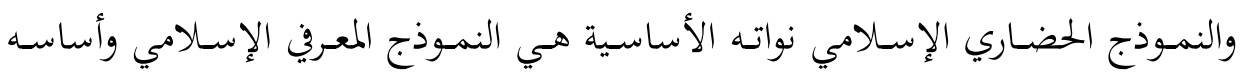

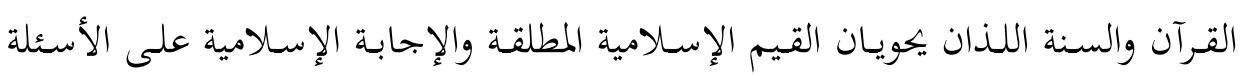

$$
\text { النهائية. 19" القوان }
$$

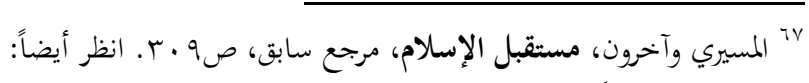

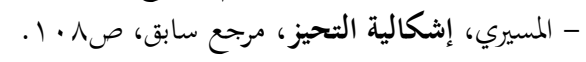

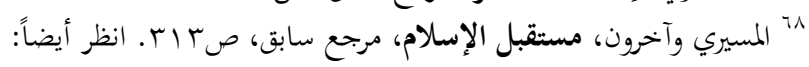

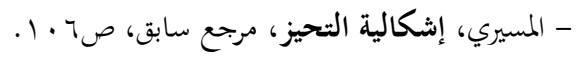

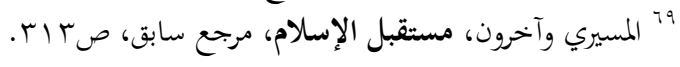


ويُعبِّر التراث عن هوية الأمة وحضارتا، وتاريخها وذاكرتها؛ فالتراث هو الذي يعطي

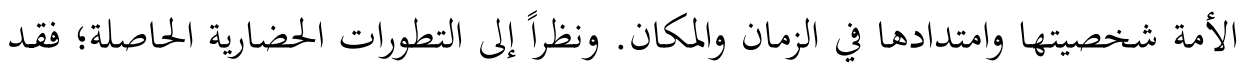

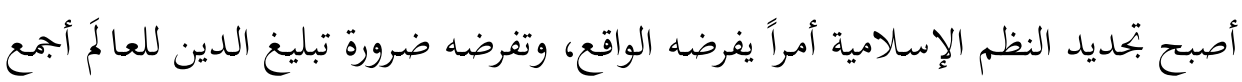

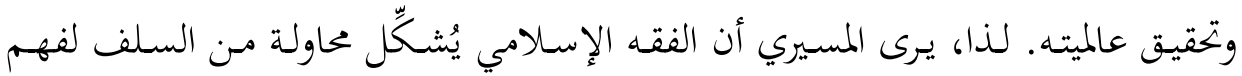
قواعد النموذج المعرفي في بُعده الشرعي في عصرهم، وأن على الإنسان المسلم اليوم -في ئي

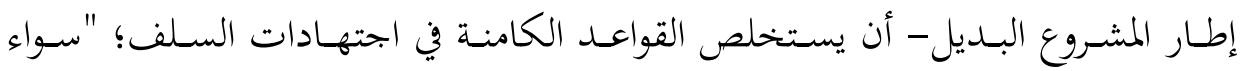

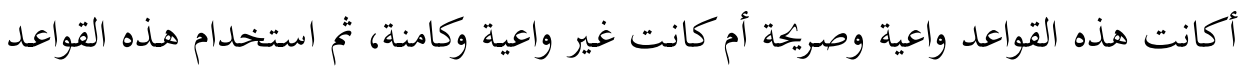

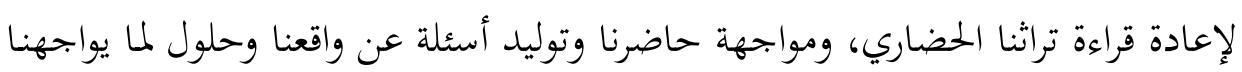

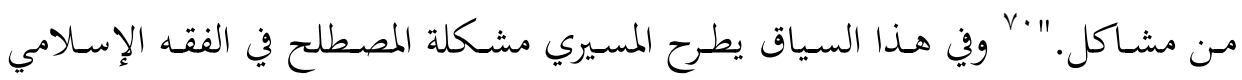

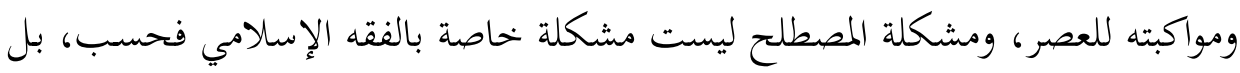

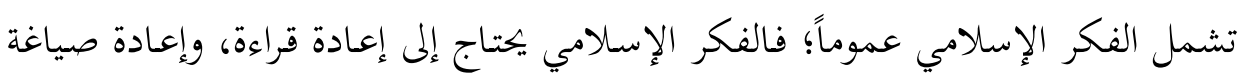
لكثير من مصطلحاته، بل يحتاج إلى إعادة نظر في كثير من قضاياه.

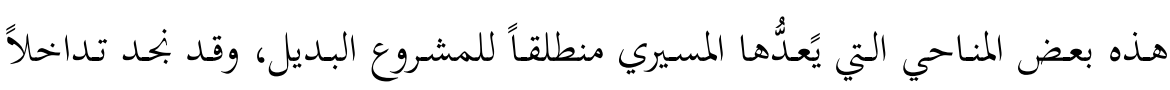

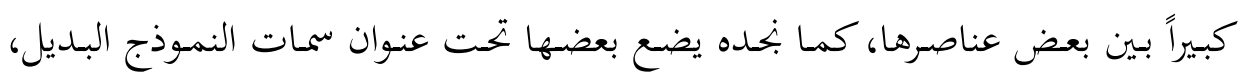

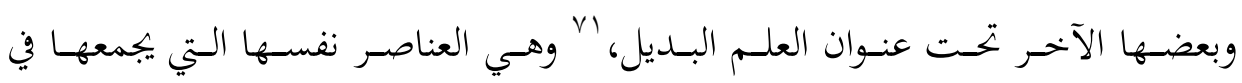
منطلقات المشروع الحداثي العربي الإسلامي.

خاتمة:

لقد كانت انطلاقة الحضارة الغربية مع مولد العقلانية والنزعة الإنسانية انطلاقة قوية،

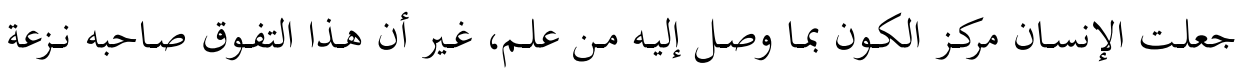

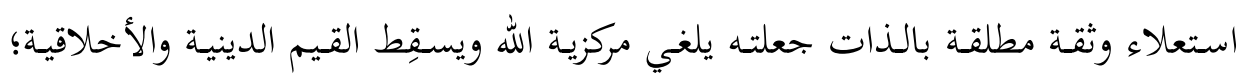
وينصِّب ذاته مرجعية مطلقة في الكون. ولم تكن هذه الخطوة التي أعطت الإنسان قيمة مركيه

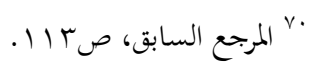

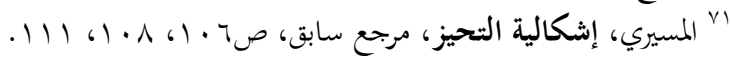

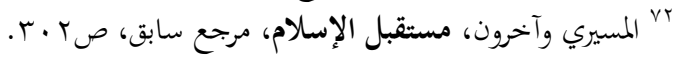


أكبر مـن قيمته، إلا بداية في متتالية هبوط قيمة الإنسان، على الرغم من تفوقه العلمي

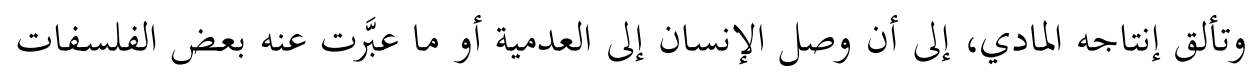

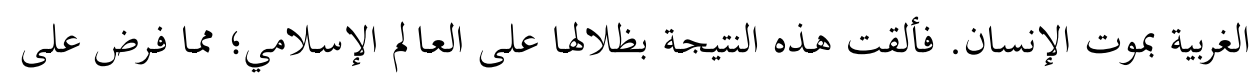

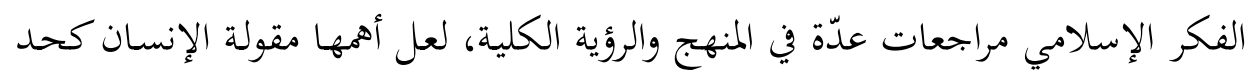
فارق بين الرؤيتين: الغربية والإسلامية، ولا تنحصر أهمية هذه المقولة في الرؤية الكلية في

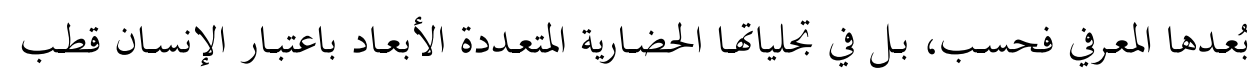
الرحى؛ ذاتاً وموضوعاً.

أما سبب اهتمامنا في هذه الدراسة بطرح المسيري المتعلّق بموضوع الإنسان؛ فمرده

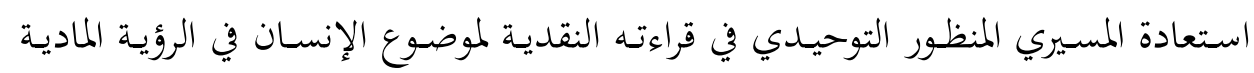

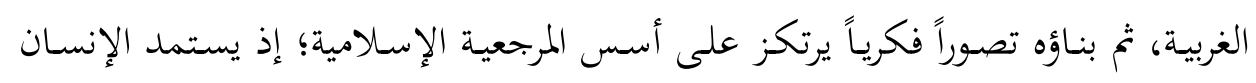

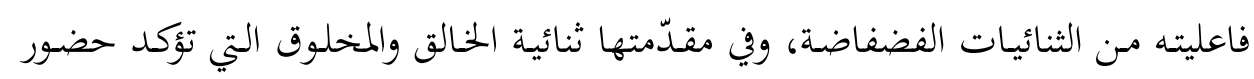

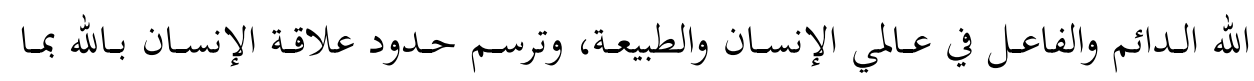

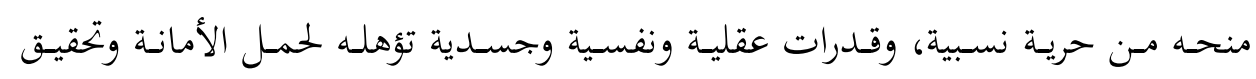

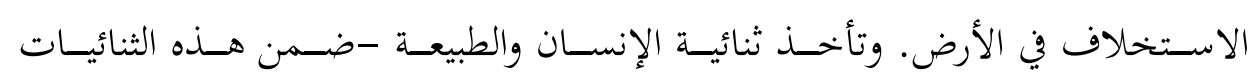

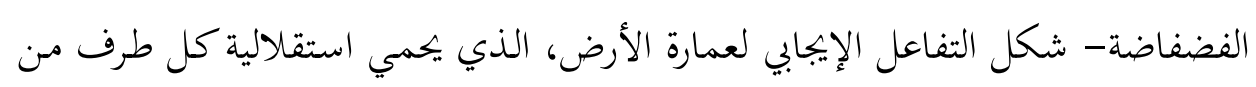
الطرفين، فلا يقعان في وحدة تطمس معالم أحدهما لمصلحة الآخر، فلا يستعلي الإنسان ويصبح مرجعية ذاته والكون كما في النزعة الهيومانية، ولا يذوب في الطبيعة وتتحكم فيه

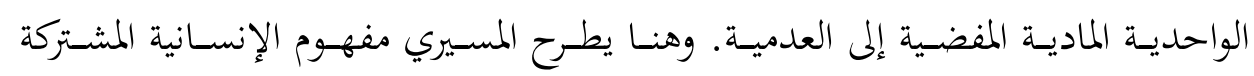

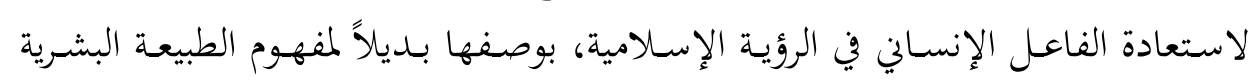

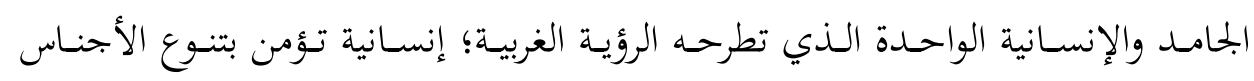

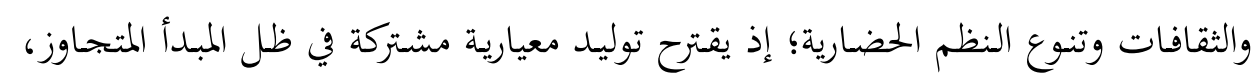
وقيم أخلاقية تستوي أمامها الإنسانية كلها.

ولم تقف رؤية المسيري للإنسان عند حـدود التنظير الفكري، بل بتحاوزته إلى مقترح

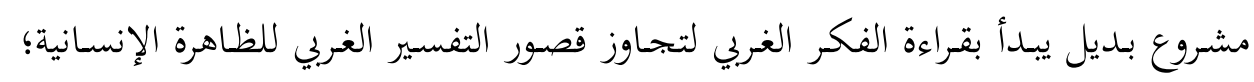


والاستفادة من نقاط القوة في منظومتها الحداثية؛ وإعادة قراءة التراث الفكري الإسلامي، واتخاذ ذلك كله شـرطاً لانطلاقة فعليـة ترتكز على فاعلية الإنسـان لبنـاء رؤيـة منهجيـة شاملة، تستوعب الأسس المنهجية للتراث المعري الإسلامي، وتفتح آفاق الاجتهاد بمنهج استكشافي توليدي.

لقـــ وضـع المسـيري أسـس القـراءة المعرفيـة بمنهجيـة النمـاذج التحليليـة؛ قصــ إعـادة

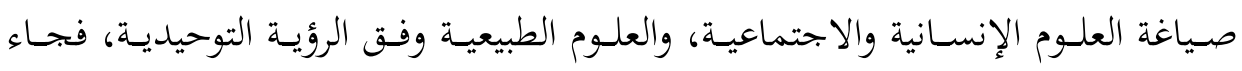

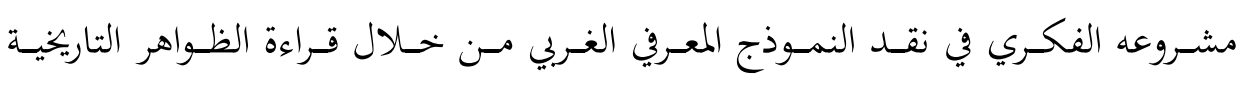

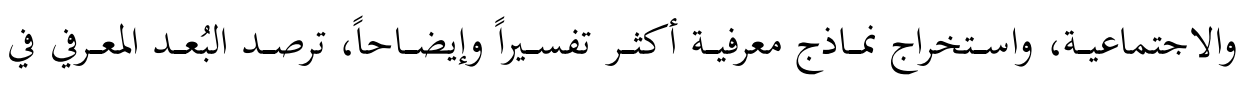

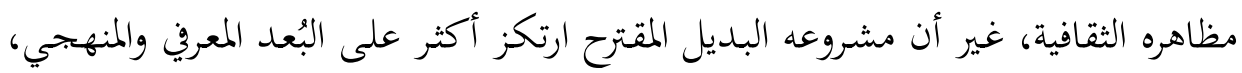

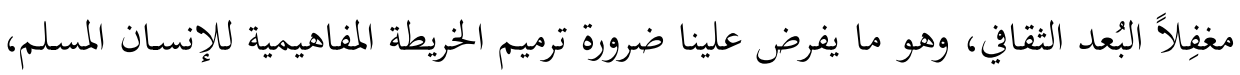

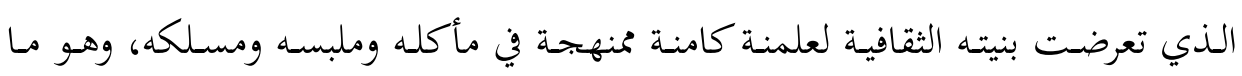

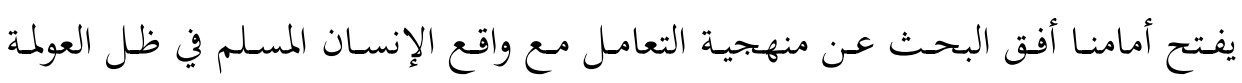
الثقافية. 